\title{
Nutrient dynamics and their control in land use systems of forest margins in Central Sulawesi, Indonesia
}

\author{
Dissertation \\ zur Erlangung des Doktorgrades \\ der Mathematisch- Naturwissenschaftlichen Fakultäten \\ der Georg-August-Universität zu Göttingen \\ vorgelegt von Georg Dechert \\ aus Frankfurt am Main
}

Göttingen, September 2003 
Referent: Prof. Dr. M. Schaefer

Koreferent: Prof. Dr. H. Ehlers

Tag der mündlichen Prüfung: 


\section{Contents}

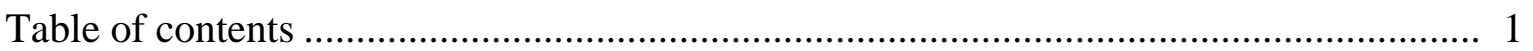

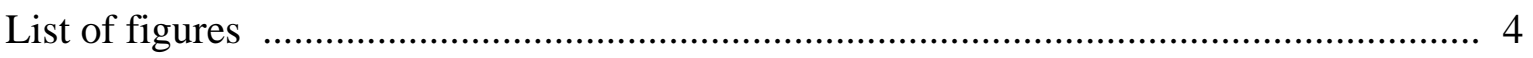

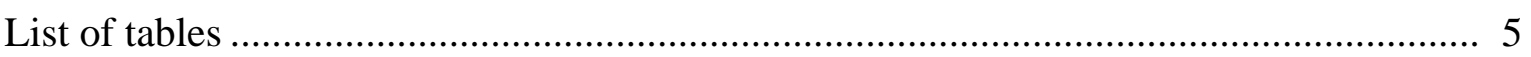

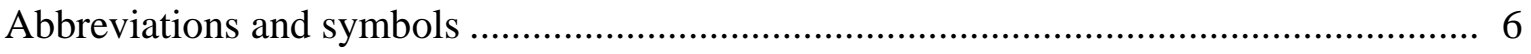

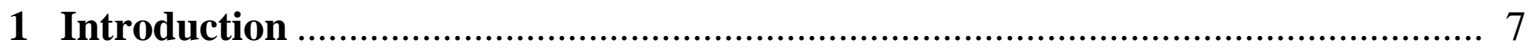

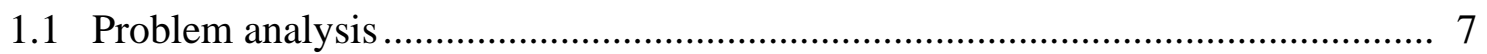

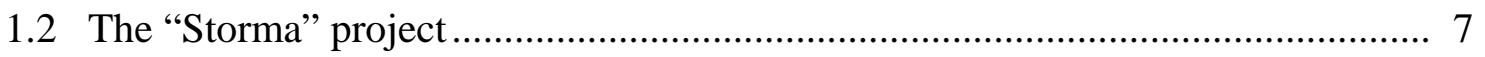

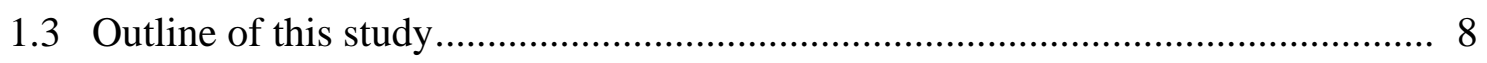

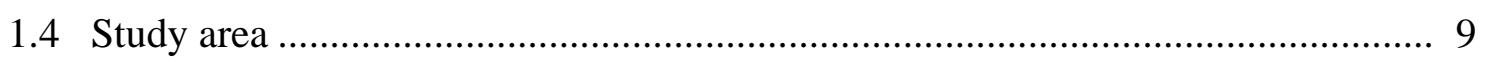

1.5 Agricultural management practice in the research area.......................................11

2 Effects of rainforest conversion and agricultural cultivation on soil parameters..16

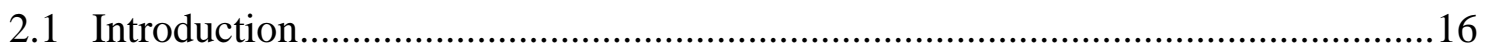

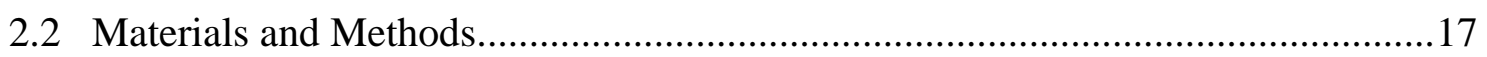

2.2.1 Sampling and sample processing ............................................................ 17

2.2.2 Soil chemical and physical analysis ..........................................................18

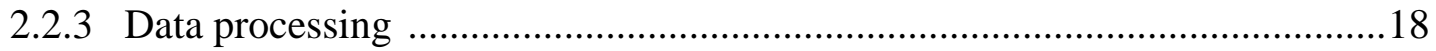

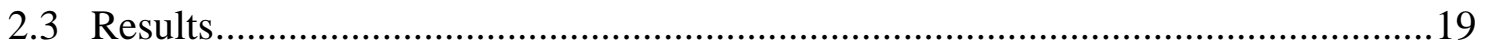

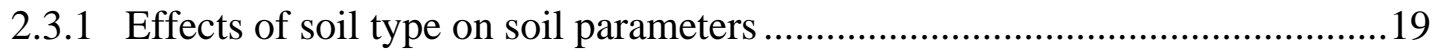

2.3.2 Effects of land use system on soil parameters ...........................................21

2.3.3 Effects of length of cultivation on soil parameters .......................................23

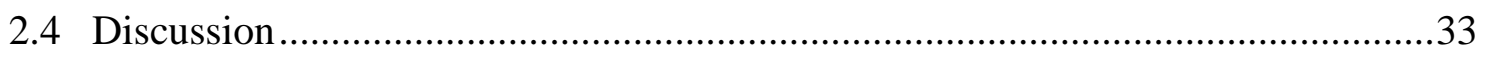

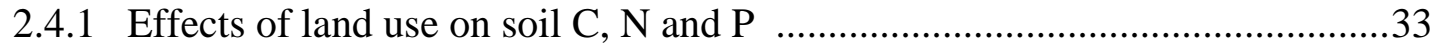

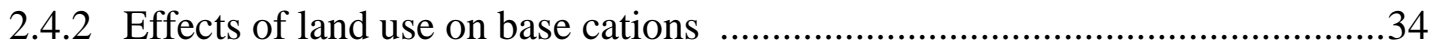

2.4.3 Effect of soil fertility on the stability of forest margins................................35

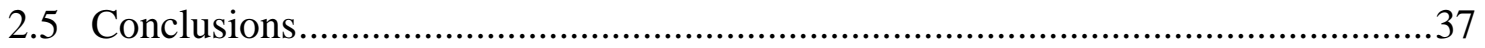


3 Gross $\mathbf{N}$ cycling activity under maize and agroforestry following rainforest

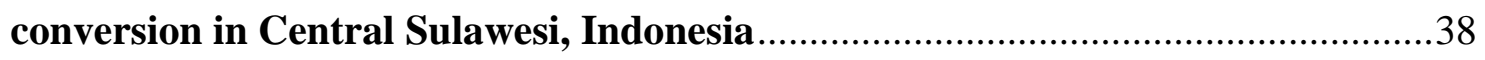

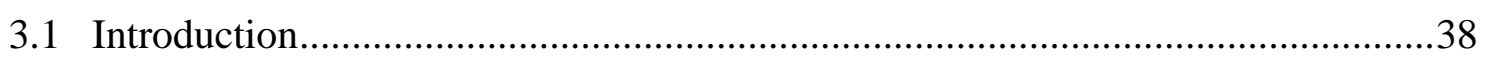

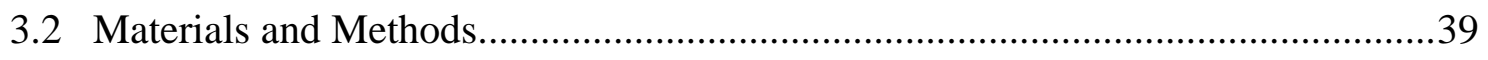

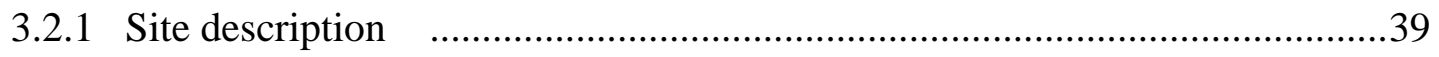

3.2.2 Sampling design

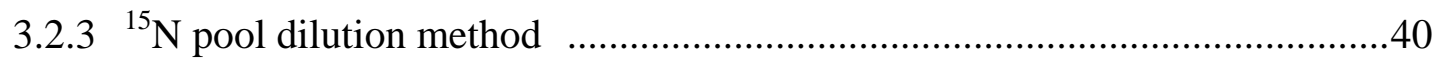

3.2.4 Other supporting soil parameters ............................................................42

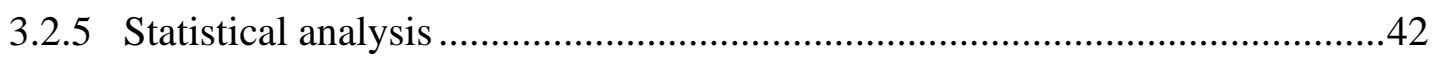

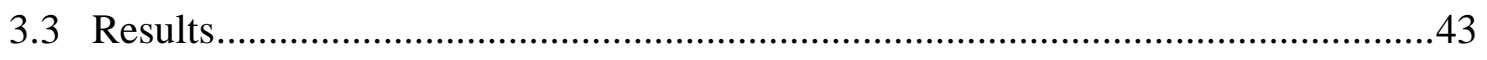

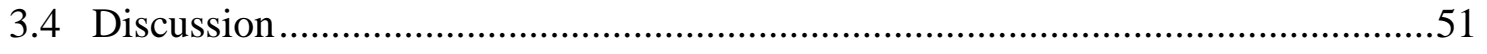

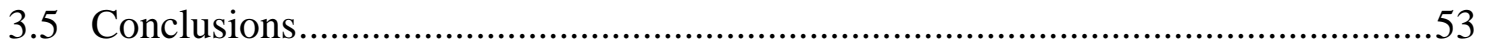

4 Nutrient balances in maize and agroforestry compared to natural rainforest ......54

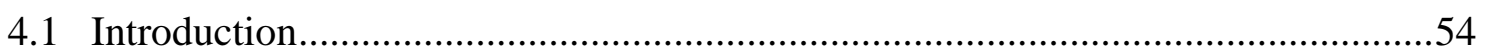

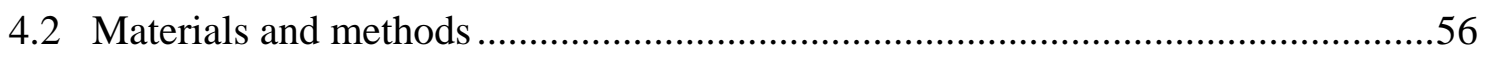

4.2.1 Sites selection and soil parameters............................................................56

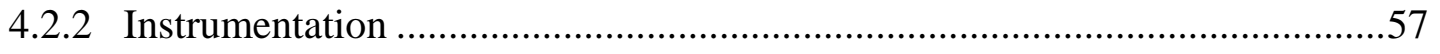

4.2.3 Water balance and leaching ….................................................................58

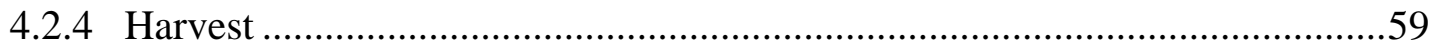

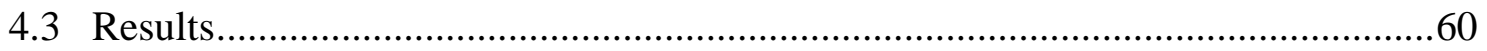

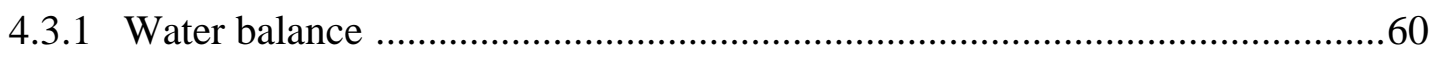

4.3.2 Nutrient input by rain and output by leaching ..............................................61

4.3.3 Harvest exports and input output balances of nutrients ...............................61

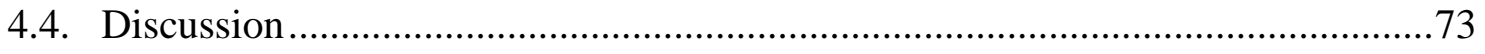

4.4.1 Nutrient balances as indicators of sustainable land use ...............................73

4.4.2 Pathways of nutrient gain and loss in maize and agroforestry.......................74

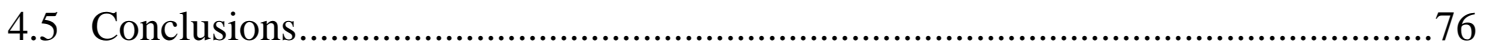




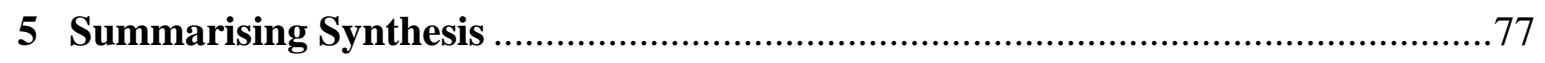

5.1 Effects of forest conversion and continuous agriculture on soil parameters .........77

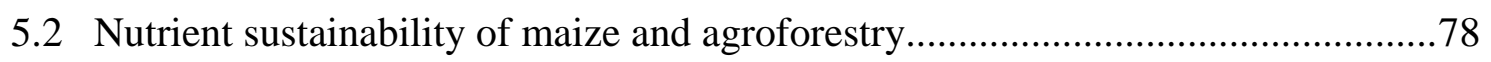

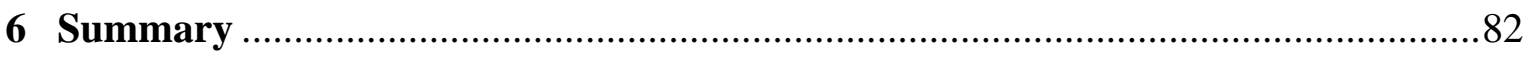

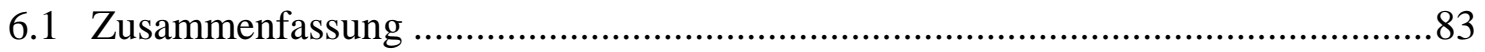

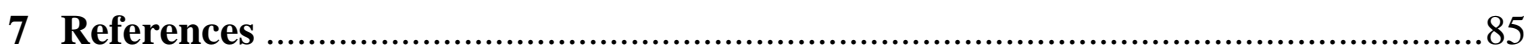

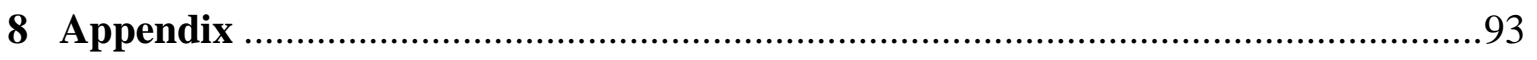




\section{List of figures}

Fig. 1. The location of the research area on the island of Sulawesi ........................... 14

Fig. 2. Agroforestry and maize sites in the research area ..........................................15

Fig. 3. Soil C concentrations and soil C stocks in different land use systems.............27

Fig. 4. Soil N concentrations and soil N stocks in different land use systems ...........28

Fig. 5. Bulk density and ECEC in different land use systems ....................................29

Fig. 6. Base saturation and total $\mathrm{P}$ in different land use systems................................30

Fig. 7. Soil K stocks and Ca saturation of ECEC in different land use systems ........31

Fig. 8. Relation between duration of cultivation and topsoil parameters ..................... 32

Fig. 9. (A) Initial $\mathrm{NH}_{4}{ }^{+}$and $\mathrm{NO}_{3}{ }^{-}$pools, and (B) ${ }^{15} \mathrm{~N}$ recovery in $\% \ldots \ldots \ldots \ldots \ldots \ldots \ldots \ldots . . . . . . . . . . . . . .48$

Fig. 10. Gross nitrification rates and gross $\mathrm{NO}_{3}{ }^{-}$consumption ..................................49

Fig. 11. (A) Gross $\mathrm{N}$ mineralisation and gross $\mathrm{NH}_{4}{ }^{+}$consumption, and (B) mean

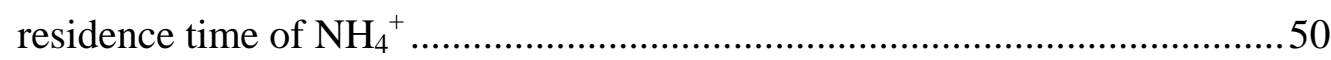

Fig. 12. Precipitation, evapotranspiration and water balance in location 1...................66

Fig. 13. Precipitation, evapotranspiration and water balance in location 2 .................67

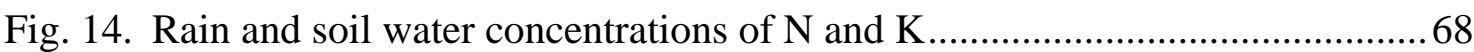

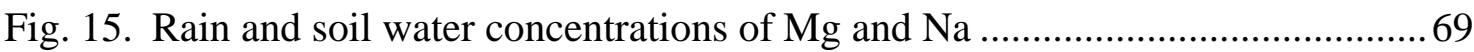

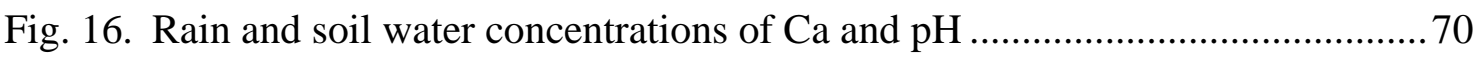

Fig. 17. Nutrient balances in 3 land use systems, location 1 ................................... 71

Fig. 18. Nutrient balances in two land use systems, location 2 ................................. 72

Fig. 19. Linear regression of soil $\mathrm{N}$ stocks during maize cultivation ............................80

Fig. 20. Nutrient balances in agroforestry and maize, with measured and estimated nutrient fluxes 


\section{List of tables}

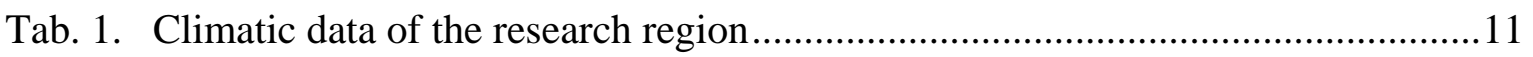

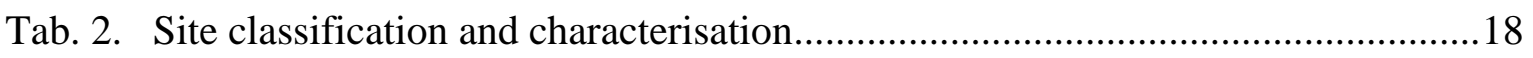

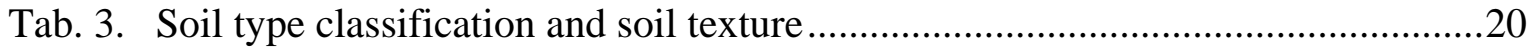

Tab. 4. Pearson's correlation coefficients between soil parameters ..................................20

Tab. 5. Nutrient stocks in litter of forest and forest fallow ..............................................22

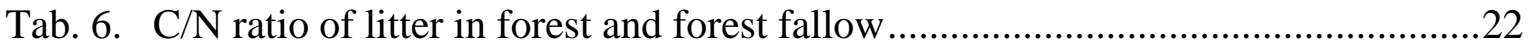

Tab. 7. Nutrient stocks, $\mathrm{pH}$, bulk density and ECEC in different land use systems .........24

Tab. 8. Nutrient concentrations, cation saturation of ECEC and base saturation in

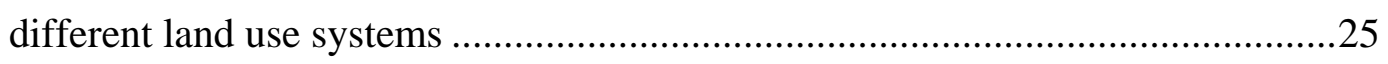

Tab. 9. Pearson’s correlation coefficients between soil parameters and length

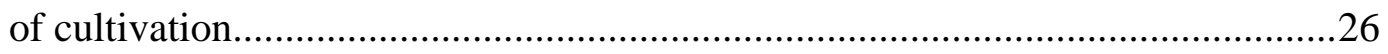

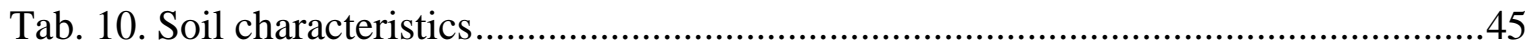

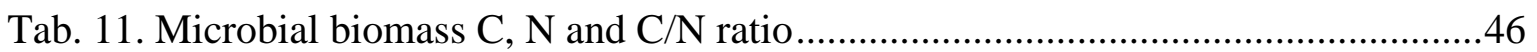

Tab. 12. Effects of land use type and locations on microbial $\mathrm{NH}_{4}{ }^{+}$cycling

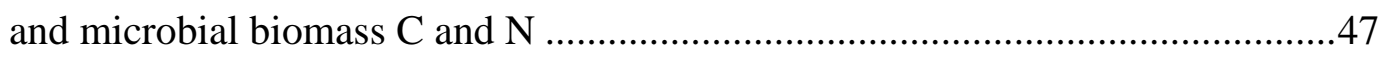

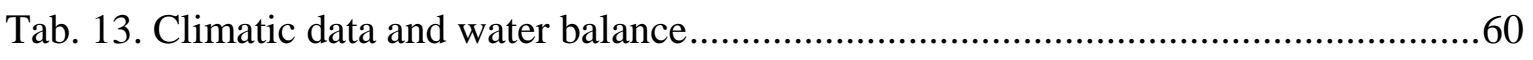

Tab. 14. Soil texture, nutrient stocks and soil parameters 0-40 cm depth..........................62

Tab. 15. Exchangeable base cation stocks and percentage of total stocks .........................63

Tab. 16. Removal of biomass by harvest.........................................................................63

Tab. 17. Annual nutrient input and output balance ..........................................................64

Tab. 18. Percentage of total losses by input and output compartment ................................65

Tab. 19. Annual losses (-) and gains (+) of nutrients as percentage of total nutrient

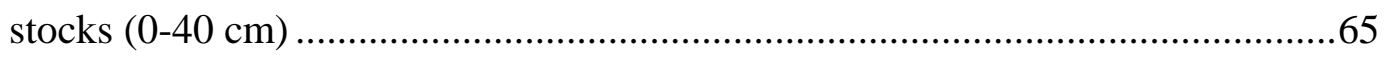

Tab. 20. Appendix: Soil survey data $0-10 \mathrm{~cm}$.................................................................93

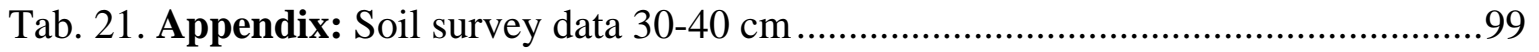

Tab. 22. Appendix: Nutrient concentrations in soil water, location 1 ...............................105

Tab. 23. Appendix: Nutrient concentrations in soil water, location 2 .............................107

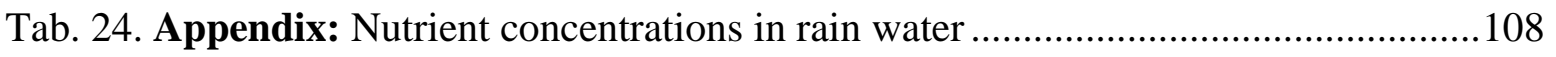

Tab. 25. Appendix: Mean soil texture in different village areas .....................................109

Tab. 26. Appendix: Nutrients removed by harvest compartment ...................................109 


\section{Abbreviations and symbols}

\begin{tabular}{|c|c|c|}
\hline $\mathrm{a}$ & Year & \\
\hline $\mathrm{AF}$ & Agroforest & \\
\hline ANOVA & Analysis of variance & \\
\hline ECEC & Effective cation exchange capacity & $\mathrm{mmol} \mathrm{kg}{ }^{-1} \mathrm{DW}$ \\
\hline d & Day & \\
\hline DW & Dry weight & g \\
\hline ET & Evapotranspiration & $\mathrm{mm} \mathrm{a}^{-1}$ \\
\hline GF & Grass fallow & \\
\hline $\mathrm{H}$ & Humidity & $\%$ \\
\hline ha & Hectar & \\
\hline ICP-OES & Inductively coupled plasma emission spectrometry & \\
\hline MBC & Microbial biomass $\mathrm{C}$ & $\mathrm{mg}$ \\
\hline MBN & Microbial biomass $\mathrm{N}$ & mg \\
\hline MF & Maize & \\
\hline $\mathrm{Mg}$ & Megagramm (ton) & \\
\hline MRT & Mean residence time & $\mathrm{D}$ \\
\hline NF & Natural forest & \\
\hline $\mathrm{NO}_{3}^{-}$ & Nitrate & \\
\hline $\mathrm{NH}_{4}^{+}$ & Ammonium & \\
\hline $\mathrm{P}$ & Precipitation & $\mathrm{mm}_{\text {day }}{ }^{-1}$ \\
\hline $\mathrm{R}$ & Global radiation & $\mu \mathrm{s} \mathrm{s}^{-1} \mathrm{~cm}^{-1}$ \\
\hline $\mathrm{SD}$ & Standard deviation & \\
\hline SE & Standard error & \\
\hline SF & Secondary forest & \\
\hline SGM & Specific gross mineralization & \\
\hline $\mathrm{T}$ & Temperature & ${ }^{\circ} \mathrm{C}$ \\
\hline
\end{tabular}




\section{Introduction}

\subsection{Problem analysis}

Indonesia is one of the major tropical rainforest areas worldwide, with $10 \%$ of the world's rainforest area and nearly $50 \%$ of Asia's remaining tropical rainforest, but Indonesia also has one of the highest deforestation rates woldwide, $1.17 \%$ annually in the last decade (FAO 2001). Most important factor causing deforestation in Indonesia is expansion of agriculture (FAO 2001).

Deforestation has often been evaluated from the rainforest conservation perspective. However, large human rural communities depend on agriculture in rainforest margin areas. According to Lanly (1985) slash and burn agriculture worldwide sustains the livelihood of estimated 500 million people, most of them in tropical and subtropical areas. Therefore studies on forest margin stability should not only focus on forest conservation but also on potentials and sustainability of agricultural practices in rainforest conversion areas.

Decreases in soil fertility during cultivation are often hypothesised to be a major cause of continuing clearing of forest for agricultural land (e.g. Nye and Greenland 1965, Andriesse 1977). This so-called "nutrient mining” is the result of of unsustainable land use systems that do not conserve nutrients. Increased leaching, harvest export, and volatilisation by burning of biomass leads to nutrient losses. If nutrient inputs are lower than nutrient outputs, the system degrades during cultivation. This hypothesis is mainly based on studies done in areas with strongly weathered and acidic soils (Andriesse and Schelhaas 1987, Hölscher 1997, Klinge 1998, Sommer 2000). However, large areas in the tropics do not have this kind of soils (e.g. Richter and Babbar, 1991; Sanchez and Logan, 1992) and the hypothesis has not been tested in areas with better soil conditions.

\subsection{The 'STORMA' project}

Large rainforest areas are still intact in the province of Central Sulawesi, and one of Sulawesis National Parks, Lore Lindu National Park, is situated about $50 \mathrm{~km}$ south-east of the province capital Palu (Figure 1). In the last decade, the valleys within and around the National Park 
were subject to intensive and widespread clearing of rainforest, and the rate of clearing increased significantly in the last 5 years (van Rheenen et al. 2003). To investigate the causes and driving factors of rainforest conversion, this region was selected as research region for a multidisciplinary research project, "Stability of rainforest margins in Indonesia” (STORMA). This project was founded by the Universities of Göttingen and Kassel-Witzenhausen, in cooperation with the Institut Pertanian Bogor (IPB), and Universitas Tadulako, Palu, Sulawesi. The project was funded by the DFG (Deutsche Forschungsgemeinschaft). Both sociological, economical, agricultural and ethnological driving factors of rainforest conversion as well as biological and hydrological consequences of rainforest clearing were studied. The present study was subproject D4 within the frame of STORMA aimed at investigating the effects of rainforest conversion and agriculture on soil fertility.

\subsection{Outline of this study}

The overall goal of this study was to test the hypothesis that declining soil fertility causes further deforestation because of declining harvest yields, forcing farmers to clear new land for agriculture. Furthermore this study was aimed at evaluating which major agricultural land use systems in forest margins is more suitable in terms of nutrient sustainability. Effects of deforestation on soil parameters and nutrient stocks were studied. Additionally, nutrient balances and gross $\mathrm{N}$ cycling activity in two major land use systems were measured and compared with natural forest as reference.

Several approaches were used to study these objectives. A survey on a regional scale was used to study long term effects of deforestation on soil parameters. Effects of continuous cultivation were studied with the chronosequence approach. Soil microbial N cycling activity was investigated with ${ }^{15} \mathrm{~N}$ pool dilution method on plot scale. Nutrient input output balances on plot scale were used to evaluate nutrient sustainability of land use systems. This study was divided in three parts, in which the above mentioned different methodologies were employed.

Part 1: Effects of deforestation were studied by sampling 74 sites during a soil survey of different land use systems and comparing the results with natural forest sites. The selected land use systems were agroforestry, maize, forest fallow, grass fallow and natural forest as undisturbed reference. Samples were analysed for soil parameters $(\mathrm{pH}$, bulk density, ECEC, 
and base saturation) and macronutrient stocks. For each agricultural site, data on the duration of cultivation was collected. This enabled to study effects of continuous agriculture on soil parameters in a chronosequence (false time series).

Part 2: In unfertilised agricultural systems like those in forest margins of Central Sulawesi, N as major plant nutrient is supplied by decomposing soil organic matter. The rate of $\mathrm{N}$ mineralisation is crucial for the productivity of these agricultural systems. ${ }^{15} \mathrm{~N}$ pool dilution method was used to study gross $\mathrm{N}$ transformation processes in agroforestry, maize, and natural forest as a reference on plot scale.

Part 3: In this part of the study nutrient input and output balances were measured on plot scale. Nutrient inputs by rain and outputs by harvest export and leaching were measured in a case study in agroforestry, maize and as a reference in undisturbed natural forest. The objective was to investigate which land use system has higher nutrient losses, and which input or output pathway is important for each plant macronutrient.

\subsection{Study area}

The study was conducted in the area around the Lore Lindu National Park in Central Sulawesi, Indonesia (Latitude $01^{\circ} 05^{\prime}-01^{\circ} 54^{\prime}$ South, Longitude $119^{\circ} 54^{\prime}-120^{\circ} 19^{\prime}$ East, Figure 1). The area is mountainous with elevations up to $2300 \mathrm{~m}$ a.s.l., and is situated about $150 \mathrm{~km}$ south of the equator in a humid tropical climate. The area is characterised by large, intact submontane and montane rainforests in the National Park area and adjacent mountains, and mostly deforested valleys and lowlands with a strong encroachment pressure both within and outside the boundary of the National Park. According to the geological map (Sulawesi 2114, 1:250.000) and preliminary surveys mainly crystalline and metamorphic parent material (granite, granodiorite, quarzite, crystalline slate and phyllite) is found in the research area. Lower parts of the slopes are mostly covered with colluvial material, and the valleys have young colluvial, alluvial and lacustrine sediments. Depending on parent material and position fluvic Cambisols, Fluvisols and Gleysols (classification following FAO, 1998a) occur in the 
valleys, and eutric or dystric Cambisols and Leptosols are found on the slopes and uplands (preliminary soil survey, unpublished data).

Due to the diverse geomorphological setting of Sulawesi the climate is characterised by large spatial variation. Whereas the main valley of the Palu river receives only $600 \mathrm{~mm}$ precipitation (making this area one of the driest in Indonesia), mountain slopes east and west of the valley may have up to 2500-3000 mm of annual precipitation. The sites selected for this study were 700-1100 m a.s.l. and received 1400-1800 mm precipitation (unpublished data from 2002, climatic stations of the project). Mean daily temperature was in the range of 20$24^{\circ} \mathrm{C}$, depending on elevation.

Main land-use system in the valleys and alluvial plains is paddy rice; the most common upland cropping systems in the research area are maize and perennial agroforestry systems with cocoa and/or coffee (Figure 2). This study concentrated on non-irrigated land use systems because conversion of natural forest rarely leads to the establishment of paddy rice, which is mostly found on land which has been cleared of forest decades ago and is located far away from forest margins.

Deforestation is continuing around villages and along roads or pathways into forest areas. Forest land which is cleared by farmers is often claimed to be traditionally part of village- or family ownership. Generally land ownership is rarely documented, and natural forest is regarded as ressource with open access for agricultural land. 
Table 1. Climatic data of the research area (December 01-December 02), annual mean of daily means (SD), for $\mathrm{P}$ : annual sum, $(\mathrm{T}=$ temperature, $\mathrm{H}=$ humidity, $\mathrm{P}=$ precipitation, $\mathrm{R}=$ global radiation)

\begin{tabular}{lrcccccc}
\hline Station & $\begin{array}{c}\text { Elevation } \\
\mathrm{m} \text { a.s.l }\end{array}$ & $\begin{array}{c}\mathrm{T} \\
{ }^{\circ} \mathrm{C}\end{array}$ & $\begin{array}{c}\mathrm{H} \\
\%\end{array}$ & $\begin{array}{c}\text { Windspeed } \\
\mathrm{m} \mathrm{s}^{-1}\end{array}$ & $\begin{array}{c}\mathrm{P} \\
\mathrm{mm} \mathrm{a}^{-1}\end{array}$ & $\begin{array}{c}\mathrm{R} \\
\mu \mathrm{s} \mathrm{s}^{-1} \mathrm{~cm}^{-1}\end{array}$ & $\begin{array}{c}\text { Cloudiness } \\
\% \text { of day }\end{array}$ \\
\hline R.kat 2 & 2275 & $14.2(0.9)$ & $86.3(7.7)$ & 0.9 & 1994 & $14.7(4.6)$ & 72 \\
R.kat 1 & 2025 & $15.6(0.9)$ & $87.3(7.3)$ & 0.9 & 1897 & $16.5(4.6)$ & 70 \\
Bariri & 1422 & $19.4(0.8)$ & $83.5(6.7)$ & 0.9 & 1765 & $18.9(3.7)$ & 58 \\
Wuasa & 1133 & $21.0(0.9)$ & $82.6(4.9)$ & 1.0 & 1596 & $18.2(3.7)$ & 63 \\
Wanga & 1128 & $21.2(0.8)$ & $81.9(5.8)$ & 0.9 & 1482 & $18.0(3.4)$ & 62 \\
Nopu & 602 & $24.6(0.9)$ & $82.8(5.5)$ & 0.8 & 1473 & $19.1(3.5)$ & 57 \\
Gimpu & 418 & $25.3(0.7)$ & $82.0(4.6)$ & 0.9 & 1645 & $19.0(3.3)$ & 58 \\
Pande. & 93 & $27.1(0.9)$ & $80.7(5.4)$ & 0.8 & 1297 & $19.8(3.5)$ & 55 \\
Palu & 80 & $27.6(1.0)$ & $76.8(6.5)$ & 1.2 & 946 & $19.8(3.5)$ & 55 \\
\hline
\end{tabular}

\subsection{Agricultural management practice in the research area}

Uplands in Central Sulawesi are confronted with large changes in land use and cultivation practice like many other rain-forest areas in Indonesia (e.g. Scholz 2001). The rainforest margins in upland Central Sulawesi are subject to intensive clear-cutting by smallholder farmers, locals and migrants, who start cultivating the cleared sites. Livelihoods of large parts of the population in rural Indonesia depend on unfertilised cropping systems in areas of converted rainforest. Traditional methods like shifting cultivation and slash-and burn agriculture are being replaced by permanent cultivation systems and introduction of cash crops.

According to survey data and satellite images about $11 \%$ of the research area is used for agriculture, $87 \%$ of people are farmers (survey data from STORMA subproject A3, internal discussion paper series). Agricultural land in upland Sulawesi originates mostly from converted natural forest, only small areas are converted grassland or old forest fallows. Forest is cleared by first cutting manually shrubs and smaller trees and then felling large trees with 
chainsaws. After extracting valuable wood species the vegetation is left to dry about 1-3 months, and then burnt. If large trees are present, burning is often repeated.

Close to rivers, lakes and generally in valley bottoms, where land can be irrigated, wet rice is planted. On non-irrigated soils (upland soils) the two main crops are maize (Zea mays L.) and mixed agroforestry systems with coffee (Coffea arabica and C. canephora L.) and cocoa (Theobroma cocoa L.). Other upland crops are cassava, beans, dryland rice, vegetables (carrots, cabbage, tomatoes, onions) and fruits (bananas, citrus) which are cultivated on a smaller scale. Most farmers have changed to permanent cultivation without fallow periods.

Maize is cultivated mainly as monoculture in continuous cropping systems without fallow, but cases of intercropping with dryland rice and beans were observed. Most farmers achieve 2-3 harvests per year. Maize harvests show high variation between $0.5-3 \mathrm{Mg} \mathrm{ha}^{-1}$ per harvest in the research region, mostly achieved without fertiliser input. This variation is caused by climatic factors, intensity of management, seed quality and soil properties. Annual precipitation is sufficient, but distribution over the year is uneven and in some months there is very little or even no rain for 3-4 weeks, which can seriously damage maize during the first months of growth. Maize planted close to rivers is endangered by flash floods following heavy rains. Weed management in the early stages is also important for yields, and weed management intensity varies, mainly because maize is managed according to time left after other crops, especially paddy rice and agroforestry, have been managed. Seed quality varies strongly, because local varieties and modern hybrids are planted. Seed harvested from hybrids are replanted again which leads to high variation even within one field. Planting hybrid seeds is limited by the high prices for the seeds, although yield is much higher than with local varieties. However, local varieties need less time to grow, according to information from farmers.

Most of the field work is done manually. Preparation of the fields includes weeding manually or spraying herbicide (mostly glyphosate) with portable sprayers, followed after some days by burning of the dry biomass. Tilling is only done in wet-rice cultivation, very rarely on nonirrigated fields. Maize is planted in rows $80-100 \mathrm{~cm}$ apart. A string is used for spacing, and within the row the seeds are planted by making holes in the soil with a stick, ca. $50-60 \mathrm{~cm}$ apart and a few centimetres deep and planting 2-3 seeds per hole. This results in about 17,000-25,000 planting holes and ca. 40,000-60,000 maize plants per hectare, depending on germination rate. Of the three seeds mostly only two plants develop. During the growing 
period weeds have to be controlled several times. Harvest is done by removing the cobs manually from the maize plant and spreading them for some days in the sun to reduce water content, which is often still high at harvest time (about 20-30 \% of dry weight). Sometimes leaves around the cobs are removed while still on the plant, to dry the cob before harvest. Harvest residues are left to dry and then cut and burned in small heaps scattered over the field, or they are left to rot without burning. The stalks in the ground are often used as markers for spacing when sowing maize again.

The agroforestry systems are mostly mixed stands of cocoa and coffee with variable proportions, with legume shade trees (Gliricidia sepium, Erythrina fusca and E. subumbrans). Plants are mostly spaced at a 2-3 m x 2-3 m grid. The soil is left undisturbed; management is manual weeding and pruning of shade trees and crop trees. Often a variety of other crops are planted in open spaces in the agroforestry systems, e.g. bananas, cassava, sweet potato, pumpkins, ginger, ananas, nut trees (Aleurites mollucana), and fruit trees (e.g. jackfruit and avocado). In the agroforestry system harvesting is done continuously throughout the year. Cocoa-pods are mostly opened immediately and only the beans are removed from the site. Coffee and Aleurites-nuts are harvested weekly, cocoa bi-weekly. Management includes cutting back the shade-trees (sometimes girdling them which makes them shed their leaves and allows more light into the stand) and frequent (about bi-weekly) cutting of the grass and weeds between the crop plants. Weeds and prunings stays on the site to decompose without burning.

Cocoa and coffee are typical cash crops, but also maize is mainly sold and only a proportion is kept for use in the producers household, whereas from paddy rice often large proportions are kept for own consumption by the producer.

Only negligible harvest exports occurred on the natural forest site. From palm trees of the genus Arenga juice is harvested, which is processed into sugar or into palm wine, and small amounts of bamboo, rattan and wood is taken from the site. In most of the forest sites close to settlements individual trees with valuable timber have been already cut down. Often farmers plant a few coffee shrubs in open spaces to claim forest sites as their property, this coffee is harvested irregularly. 


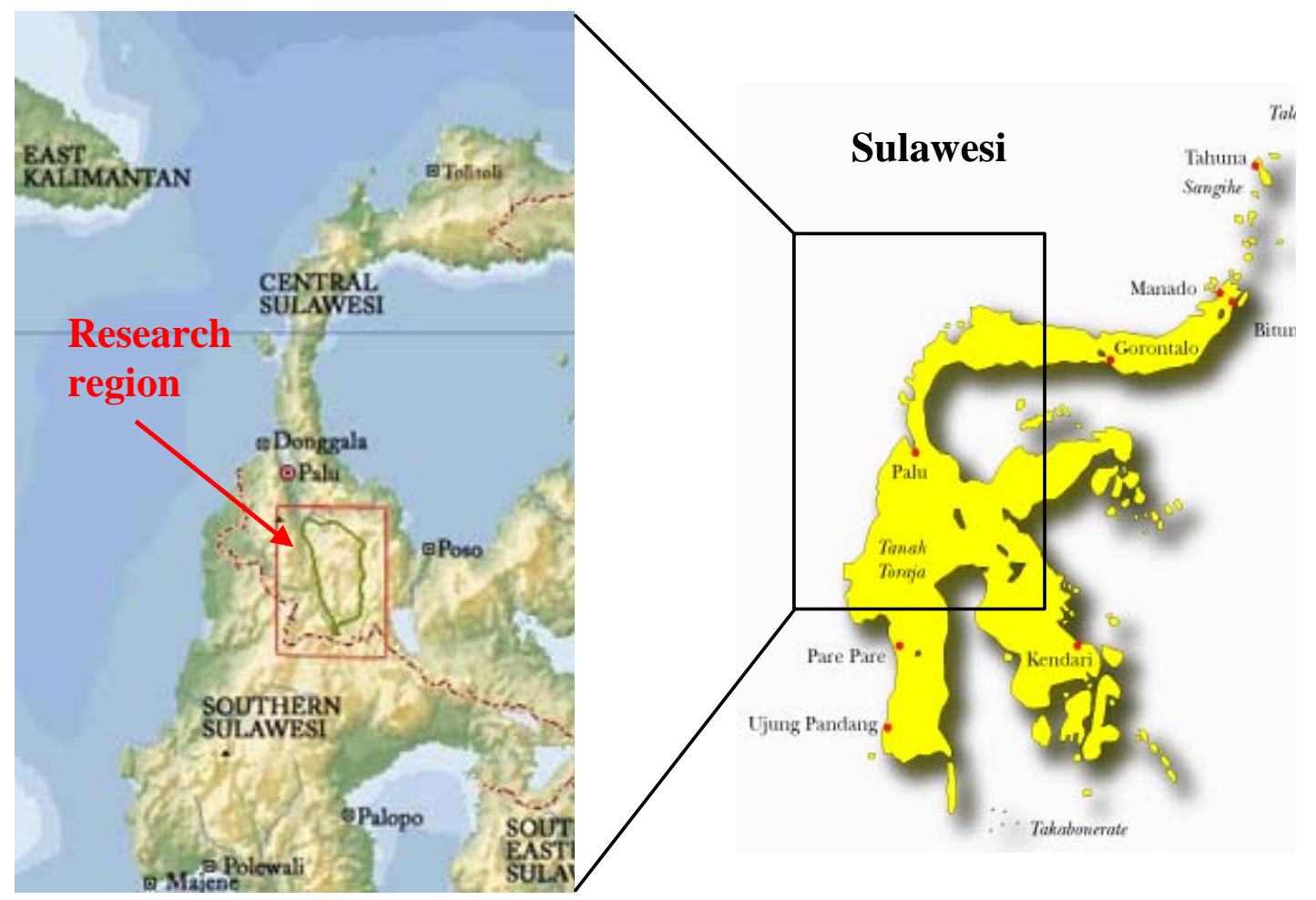

Figure 1. The location of the research region on Sulawesi, Indonesia. The green line on the left map indicates the border of the Lore Lindu National Park. 

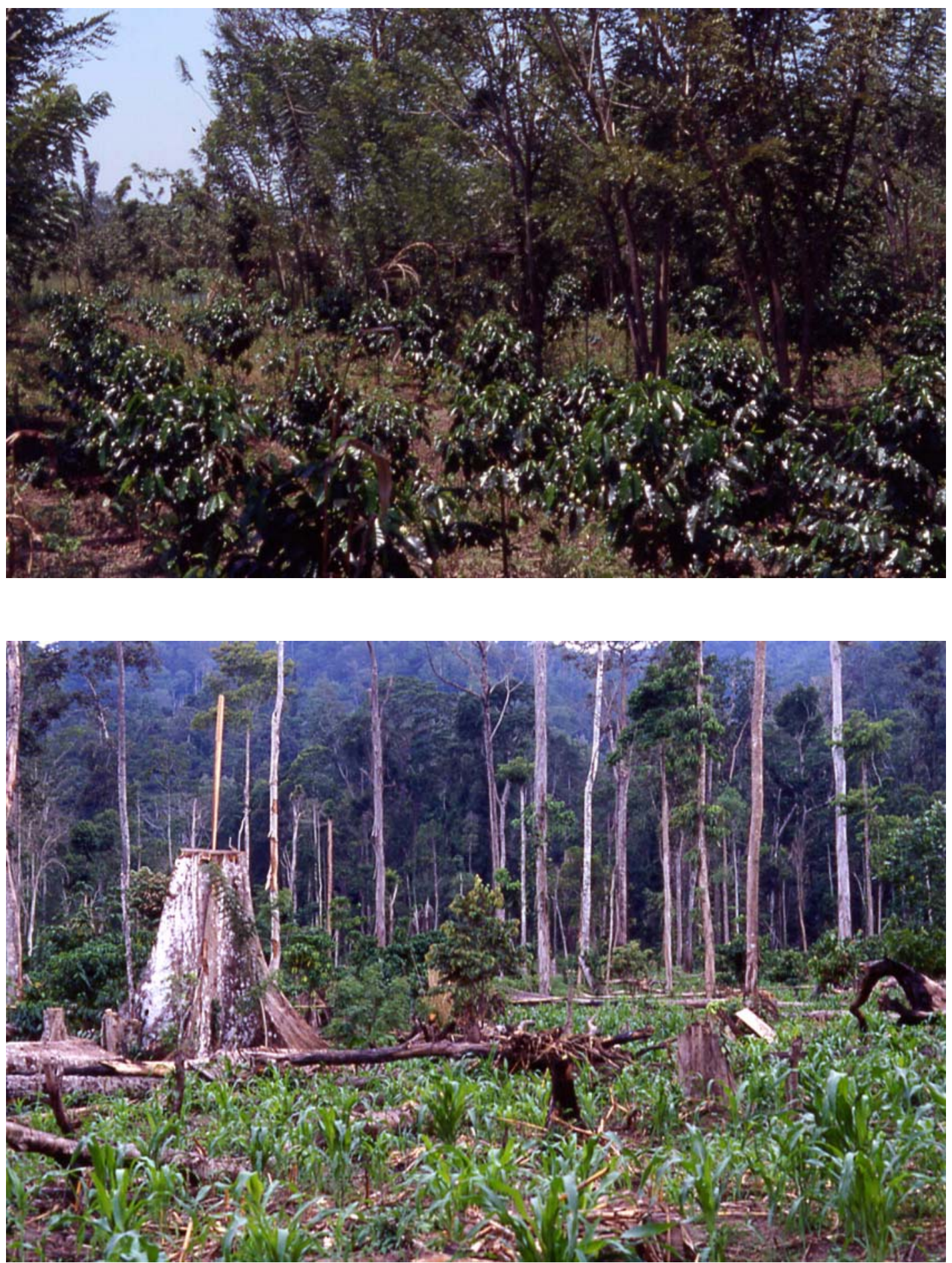

Figure 2. Above: Agroforestry with coffee and legume shade trees (Gliricidia sepium). Below: Maize crop on converted rainforest site, about 1 year after clear cutting, background: natural rainforest. 


\section{2}

\section{Effects of rainforest conversion and agriculture on soil parameters and nutrient stocks}

\subsection{Introduction}

The uplands of Central Sulwesi have been subject to widespread clear cutting of natural rainforest, mainly by smallholder farmers, in the last decade. The rate of annually cleared land has increased significantly in the last 5 years (Van Rheenen et al. 2003).

The type of land use established after forest clearing has a major influence on the changes in soil fertility. Forest clearing for annual crops (e.g. upland rice or maize) removes the major source of litter and therefore reduces the supply of organic material to the soil. In addition, the soil organic matter stock continues to decompose, possibly at higher rate, as removal of the forest cover leads to higher temperatures of the soil. Therefore it was expected that clear cutting and conversion of rainforest to annual crops lead to a decline in soil organic matter. This has been shown in previous studies under different climatic conditions (e.g. Schlesinger 1986, Davidson et al. 1993, Guo and Gifford 2002). Declining soil organic C may lead to a reduced effective cation exchange capacity (ECEC) and reduced N stocks. A reduced ECEC may make cations more vulnerable to leaching which after some time of cultivation may result in a reduced cation stock or reduced base saturation. In contrast to annual cropping systems, agroforestry systems with their perennial crops and shade trees have a continuous vegetation cover which provides litter and shading to the soil. Soil parameters may improve in these systems compared to annual crops (Beer et al 1998).

The research objective was to study if declining soil fertility forces farmers to clear natural forest to maintain harvest yields. The research area in Central Sulawesi is characterised by relatively young and fertile soils. This study was conducted to answer the following research questions:

a) Which soil characteristics change after the conversion of forest to agricultural land?

b) What is the influence of time of maize- or agroforestry cultivation on soil parameters?

c) Does declining soil fertility force farmers to clear new areas for agriculture?

To answer these questions, 74 sites were sampled divided over 5 villages covering 4 major land-use systems found in the research area (maize, agroforestry with cocoa and coffee, tree- 
dominated fallow and grass-dominated fallow) and analysed for parameters that indicate the soil fertility. To avoid the effects of selective conversion of forest on fertile soils all agricultural sites were compared with forest sites on the same soil type and landscape location.

\subsection{Material and methods}

Sampling sites were identified and sampled in the period from April-September 2001. In five villages (Wuasa, Wanga, Nopu, Lempelero and Rompo) and their surrounding area a total of 74 sites were sampled. All these villages were situated around the Lore Lindu Nation Park in Central Sulawesi, Indonesia. Sites of five major land use systems were selected and sampled: maize, cocoa and/or coffee agroforestry, forest fallow, grass-fallow and natural forest as reference sites for the undisturbed situation (Table 2). Forest fallow is mainly found on newly cleared forest sites which are not immediately cultivated, or on agricultural fields which have been abandoned. Grass fallows were mostly found on areas which had never been cultivated or on sites with longer continuous annual crop cultivation. On these sites frequent burning favours establishment of grass species, especially Imperata cylindrica. All sites were between 400 and 1100 m elevation. All sites were visited together with the owner of the plot, and the owner was interviewed on site about the age of the site since clear cutting, management practice, and previous crops. Sites which had received fertiliser input in the last 5 years were excluded from the survey.

\subsubsection{Sampling and sample processing}

From each site fifteen soil samples were taken with an auger at randomly chosen points from fixed depths (0-0.1 $\mathrm{m}$ and 0.3-0.4 m). Sub-samples of five sampling points were mixed to form three composite samples per site to reduce small scale variation within the sites. Per composite sample about 300 g of field-moist soil was transported to the laboratory. Soil was weighed and dried at $45{ }^{\circ} \mathrm{C}$ within 1-2 days and passed through a $2 \mathrm{~mm}$ sieve. In addition, bulk density was sampled on each site for both depths (0-0.1m and 0.3-0.4 m) using three 100 $\mathrm{cm}^{3}$ steel cylinders per site. Bulk density samples were transported in plastic bags and dried in the laboratory at $105{ }^{\circ} \mathrm{C}$ in paper bags and weighed. In forest and forest fallow sites, where 
substantial amounts of litter were present, litter height was measured and three samples from a $0.3 \mathrm{~cm} \times 0.3 \mathrm{~cm}$ square were taken.

\subsubsection{Soil chemical and physical analysis}

All soil samples were analysed for total carbon and nitrogen. The air-dried and sieved soil samples were ground to powder using a ball mill. Total organic $\mathrm{C}$ was determined using an automated C \& $\mathrm{N}$ analyser (Heraeus vario EL). Exchangeable cations $\left(\mathrm{Ca}^{2+}, \mathrm{Mg}^{2+}, \mathrm{K}^{+}, \mathrm{Na}^{+}\right.$, $\mathrm{Al}^{3+}$ and $\mathrm{H}^{+}$) were determined by percolation with $1 \mathrm{M} \mathrm{NH}_{4} \mathrm{Cl}$ following the method described in Meiwes et al. (1984). Total phosphorus and $\mathrm{Ca}, \mathrm{Mg}, \mathrm{K}, \mathrm{Na}, \mathrm{Al}$, and Fe were determined after digestion under pressure with $\mathrm{HNO}_{3}$ following the method described in Heinrichs (1989). Effective cation exchange capacity (ECEC) was calculated from exchangeable cations at field $\mathrm{pH}$. Litter samples were analysed for $\mathrm{C}$ and $\mathrm{N}$ only. Soil texture was determined using the pipette method.

Table 2. Site classifications and characteristics

\begin{tabular}{|c|c|c|c|}
\hline & $\mathrm{n}$ & Abbreviation & Vegetation \\
\hline Natural forest & 12 & NF & Sub-montane tropical rain forest \\
\hline Forest fallow & 11 & SF & Tree-or shrub dominated fallow, age 2-10 years \\
\hline Agroforest & 15 & $\mathrm{AF}$ & $\begin{array}{l}\text { Mixed cocoa/coffee-agroforestry with shade } \\
\text { trees trees (Gliricidia or Erythrina) }\end{array}$ \\
\hline Maize & 28 & MF & Maize fields, monoculture without fallow period \\
\hline Grass fallow & 8 & GF & Grass-dominated fallow \\
\hline
\end{tabular}

\subsubsection{Data processing}

Nutrient stocks were calculated using bulk density data and nutrient concentrations. Because of the large variation in soil characteristics, differences between soil parameters can also be caused by soil type, slope, elevation etc. To avoid this not only nutrient concentrations and stocks were analysed, but natural forest sites on the same soil types and landscape location 
were used as reference and relative differences of land use type compared to forest were calculated.

For each variable normal distribution was tested $(P<0.1$, Shapiro-Wilks W-test). Analysis of variance (one-way ANOVA and Tukey's means separation) was used to test for significant effects of soil type, land use system and length of cultivation on soil properties. Pearson's product moment correlation coefficients were calculated to relate duration of cultivation with soil characteristics in maize and agroforestry systems. Data were analysed using STATISTICA 6.0.

\subsection{Results}

\subsubsection{Effects of soil type on soil parameters}

Generally soils in the research region were young and fertile, not acidic or deeply weathered. $53 \%$ had $\mathrm{pH}_{(\mathrm{KCl})}$-values above 5.0. Al-saturation of the ECEC increased with depth, but in the topsoil never exceeded $15 \%$; only 5 of the 74 sites had an Al-saturation which was higher than $10 \%$. Base saturation was mostly above $80 \%$, with Ca contributing about $70 \%$, Mg contributing about $20 \%$ and $\mathrm{K}$ contributing about $5 \%$.

Sampled soils were classified into three groups depending on landscape position and parent material. This classification into three soil types corresponded well with the texture analysis (Table 3). Silt percentage was similar in all soil types (33-38 \%), but sand was highest in soils on weathered schist and lowest in slopes on weathered phyllite, whereas clay was high in soils on weathered phyllite and low in sites on weathered schist. No statistically significant differences were found if land use systems were classified separately for each soil type. Soil on weathered schist showed a tendency to higher bulk density and largest differences of soil parameters between natural forest and cultivated sites, and carbon-, nitrogen stocks and ECEC were generally higher in soils on weathered phyllite than on alluvial sediments or weathered schist.

Clay content of soils was positively correlated with C-, Al-, and Fe- stocks, and negatively correlated with bulk density and sand content. Silt content of soils was positively correlated with Mg- stocks. Carbon and Nitrogen concentrations were closely correlated; ECEC was 
positively correlated with $\mathrm{pH}$ (Pearson's correlation, $P \leq 0.05$ ). ECEC was correlated (but not significantly) with C concentration (Table 4).

Table 3. Mean soil parameters on different soil types

\begin{tabular}{lccc}
\hline parameter & $\begin{array}{c}\text { Slopes, } \\
\text { weathered schist }\end{array}$ & $\begin{array}{c}\text { Alluvial } \\
\text { sediments }\end{array}$ & $\begin{array}{c}\text { Slopes, } \\
\text { weathered phyllite }\end{array}$ \\
\hline Clay [\%] & $14.2(5.0)$ & $20.1(6.9)$ & $41.3(18.6)$ \\
Sand [\%] & $52.0(9.1)$ & $40.4(16.7)$ & $21.9(11.7)$ \\
Silt [\%] & $33.9(7.0)$ & $39.5(13.0)$ & $36.8(7.6)$ \\
$\mathrm{C}\left[\mathrm{Mg} \mathrm{ha}^{-1}\right]$ & $28.0(1.2)$ & $33.5(1.4)$ & $45.5(4.9)$ \\
$\mathrm{N}\left[\mathrm{Mg} \mathrm{ha}^{-1}\right]$ & $2.4(0.1)$ & $3.1(0.1)$ & $3.5(0.3)$ \\
$\mathrm{BD}\left[\mathrm{g} \mathrm{cm}^{-3}\right]$ & $1.14(0.03)$ & $1.08(0.02)$ & $0.95(0.02)$ \\
ECEC [mmol kg & $131.4(11.7)$ & $178.4(11.3)$ & $150.8(31.4)$ \\
$\mathrm{BS}[\%]$ & $94.9(1.0)$ & $97.2(0.9)$ & $70.6(9.7)$ \\
pH [KCl] & $5.0(0.6)$ & $5.2(0.6)$ & $5.2(0.6)$ \\
\hline
\end{tabular}

Table 4. Pearson's correlations coefficients between soil parameters, topsoil $(0-10 \mathrm{~cm})$

\begin{tabular}{cccc}
\hline $\mathrm{X}$ & $\mathrm{Y}$ & $\mathrm{R}$ & $\mathrm{p}$ \\
\hline ECEC & $\mathrm{C} \mathrm{\%}$ & 0.5 & 0.500 \\
Clay \% & ${\mathrm{C}\left[\mathrm{Mg} \mathrm{ha}^{-1}\right]}$ & 0.8 & 0.001 \\
Clay \% & $\mathrm{Al}[\%$ of ECEC $]$ & 0.8 & 0.001 \\
Clay \% & Sand \% & -0.8 & 0.001 \\
Clay \% & Bulk density & -0.6 & 0.002 \\
Silt \% & $\mathrm{Mg}\left[\mathrm{Mg} \mathrm{ha}^{-1}\right]$ & 0.6 & 0.001 \\
C \% & $\mathrm{N} \%$ & 0.9 & $<0.001$ \\
ECEC & $\mathrm{pH}$ & 0.7 & 0.001 \\
\hline
\end{tabular}




\subsubsection{Effects of land use system on soil parameters}

If non-standardised data were compared to natural forest in topsoil only bulk density, base saturation and Ca-saturation of ECEC increased in converted sites, all other parameters showed decline in managed or fallow systems compared to natural forest (Table 7 and 8). Statistically significant differences were found in topsoil $\mathrm{C}$ and $\mathrm{N}$ stocks, which were statistically significantly lower in agroforestry and maize compared to natural forest (one way ANOVA, $P \leq 0.05$ ), grass fallow was similar to maize and forest fallow intermediate between natural forest and cultivated sites. ECEC decreased from natural forest $>$ forest fallow $>$ agroforestry and maize > grass fallow. Grass fallow had lower $\mathrm{pH}$, topsoil ECEC, base saturation and $\mathrm{C}$ and $\mathrm{N}$ stocks compared to all other land-use systems, and also statistically significantly higher Al-saturation and lower Ca-saturation of ECEC (one-way ANOVA, $P \leq$ 0.05). Increase of topsoil P stocks in converted systems was not significant. In the subsoil ECEC was higher in converted sites than in natural forest (Table 7 and 8).

Litter was found in substantial amounts only in natural forest and forest fallows. Agroforestry systems had only very thin layers of litter, and also grass fallows had some litter, but these sites were burnt regularly and litter did not accumulate. Forests had higher litter stocks than forest fallows, in both systems $\mathrm{C}$ and $\mathrm{N}$ stocks in litter were around $20 \%$ of soil stocks in 0 $10 \mathrm{~cm}$ depth (Table 5). Litter from soil type C had much higher C:N- ratio compared to soil type $\mathrm{A}$ and $\mathrm{B}$ (Table 6). It must be noted that soil type $\mathrm{C}$ also had lower $\mathrm{pH}$ and base saturation than soil type $A$ and $B$.

If data were standardised with forest as reference, Carbon- and Nitrogen concentrations and stocks in topsoil declined after conversion (Figure 2 and 3, ANOVA, $P \leq 0.05$ ). The losses of C -stocks after rain forest conversion to agroforestry and maize were $19 \%$ for both land uses in $0-10 \mathrm{~cm}$ and $6 \%$ and $10 \%$ in 30-40 cm, respectively. Losses of N-stocks after conversion to agroforestry and maize were $20 \%$ and $21 \%$ in $0-10 \mathrm{~cm}$ depth and $10 \%$ and $19 \%$ in 30-40 $\mathrm{cm}$ depth, respectively. Decreases in concentrations of $\mathrm{C}$ after conversion to maize and agroforestry were as high as $29 \%$ and $26 \%$ in $0-10 \mathrm{~cm}$ and $7 \%$ and $8 \%$ in 30-40 cm depth. Soil N concentrations decreased after conversion to agroforestry and maize by $30 \%$ and $28 \%$ in 0-10 cm depth and by $12 \%$ and $16 \%$ in 30-40 cm depth, respectively. In 30-40 cm depth C and $\mathrm{N}$ decreased less in the cultivated systems and were similar to natural forest in forest fallow and grass fallow. 
Topsoil bulk density in all land-use systems was higher than natural forest; highest values were found in agroforestry followed by maize (Figure 4, ANOVA, $P \leq 0.05$ ). ECEC was similar in forest and forest fallow, and lower in agroforesty and maize, with lowest values in grass fallow (Figure 5, ANOVA, $P \leq 0.05$ ). BS showed no changes in the topsoil, but in 30-40 cm depth a tendency to increase was observed in converted sites. Total P did not show significant changes in different land use systems (Figure 5). Total K stocks did not change after forest conversion, but Ca-saturation of ECEC was significantly higher in converted sites compared to forest in 30-40 cm depth (Figure 6, ANOVA, $P \leq 0.05$ ).

Table 5. Nutrient stocks in litter of forest and forest fallow, mean and standard deviation.

\begin{tabular}{lcccc}
\hline & $\begin{array}{c}\text { Biomass } \\
\mathrm{t} \mathrm{ha}^{-1}\end{array}$ & $\begin{array}{c}\mathrm{C} \\
\mathrm{t} \mathrm{ha}^{-1}\end{array}$ & $\begin{array}{c}\mathrm{N} \\
\mathrm{kg} \mathrm{ha}^{-1}\end{array}$ & $\begin{array}{c}\mathrm{C} / \mathrm{N} \\
\text { ratio }\end{array}$ \\
\hline Natural forest & $33.0(6.3)$ & $12.2(4.9)$ & $438.1(193.9)$ & $29.8(9.4)$ \\
Forest fallow & $19.1(6.3)$ & $7.4(2.7)$ & $309.7(145.6)$ & $25.5(6.0)$ \\
\hline
\end{tabular}

Table 6. C/N-ratio of litter in natural forest and forest fallow in different soil types

\begin{tabular}{lccc}
\hline & \multicolumn{3}{c}{ Soil type } \\
& A & B & C \\
\hline Natural forest & $29.8(7.0)$ & $20.6(2.7)$ & $39.1(12.7)$ \\
Forest fallow & $28.5(5.0)$ & $23.9(6.5)$ & - \\
\hline
\end{tabular}

\subsubsection{Effects of length of cultivation on soil parameters}

Topsoil (0-10 cm) carbon- and nitrogen-stocks decreased in maize during cultivation $(\mathrm{P}=0.02$ and 0.04, respectively) and showed no significant change in time in agroforestry ( $P=0.45$ and 0.53, respectively, Table 9, Figure 8). Bulk density increased significantly with age in maize 
$(\mathrm{P}=0.03)$, but did not change in agroforestry $(\mathrm{P}=0.57)$. ECEC increased during cultivation in agroforestry, but showed no clear trend in maize $(P=0.04$ and 0.07 , respectively, Table 9$)$. Potassium saturation of ECEC decreased strongly in maize fields during cultivation from high values ( $\mathrm{P}=0.004)$, in agroforestry no changes were observed in the false time series (Figure 8). Changes of total P stocks in time were not significant in both land use systems. Results from subsoil $(30-40 \mathrm{~cm})$ showed generally smaller and non-significant changes of soil parameters after conversion of forest than in topsoil, except for Ca-saturation of ECEC, which in both agroforestry and maize increased after conversion in 30-40 cm depth $(\mathrm{P}=0.003$ and 0.02, respectively, Table 9). 
Table 7. Nutrient stocks, pH, bulk density and ECEC in different land use systems, all sites (mean and standard error, different letters indicate statistically significant differences between land use systems, ANOVA, Tukey’s Means Comparison, $P<0.05$ )

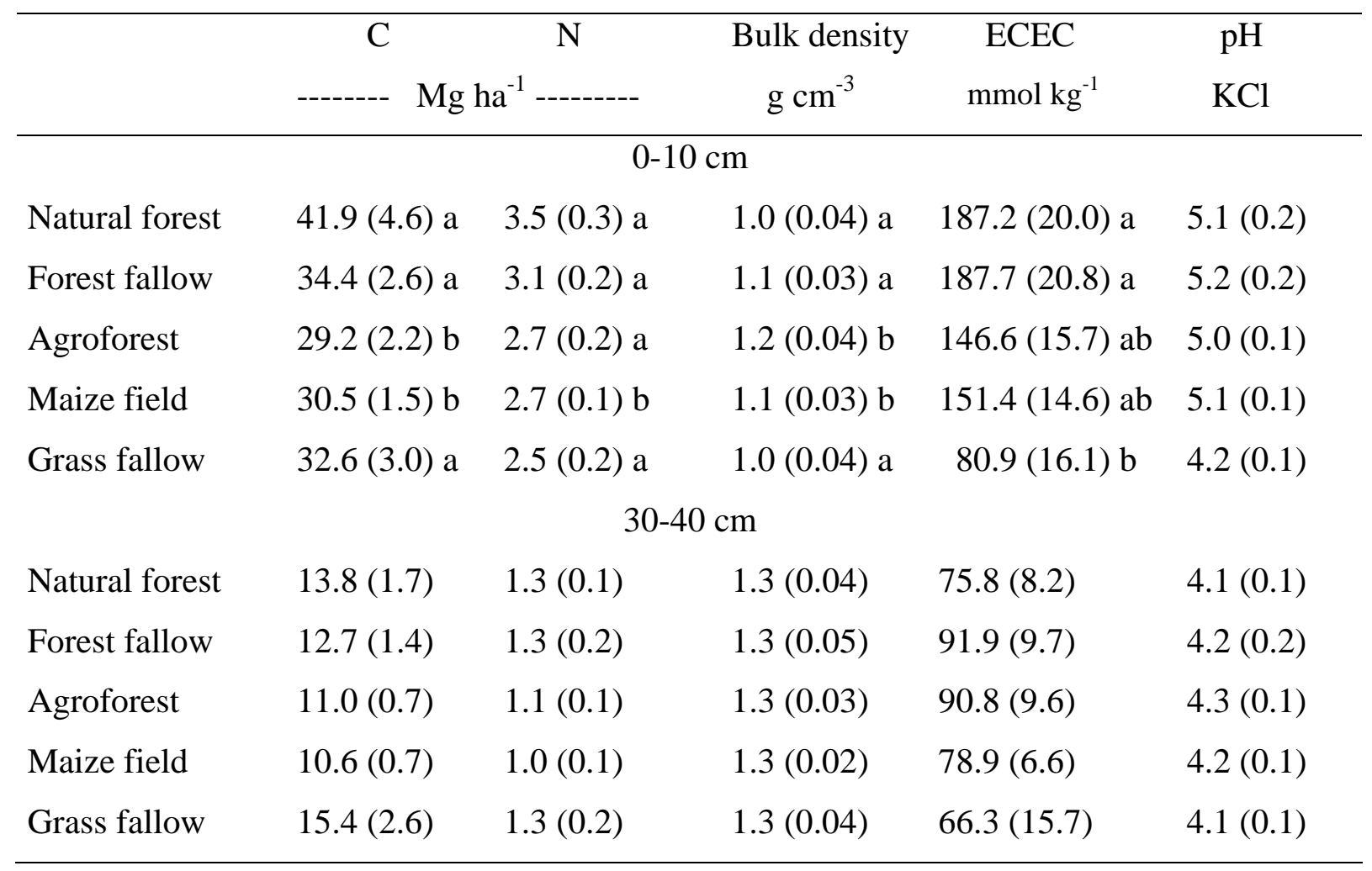


Table 8. Nutrient concentrations, cation saturation of ECEC and base saturation (mean and standard error, different letters indicate statistically significant differences between land use systems, ANOVA, Tukey’s Means Comparison, $P<0.05$ )

\begin{tabular}{lcccccc}
\hline & $\mathrm{C} \%$ & $\mathrm{~N} \%$ & $\mathrm{Ca}[\% \mathrm{CEC}]$ & $\mathrm{Al}[\%$ ECEC] & base sat. \% \\
\hline Natural forest & $4.5(0.6) \mathrm{a}$ & $0.38(0.04) \mathrm{a}$ & $67.4(4.0) \mathrm{a}$ & $3.3(2.1) \mathrm{a}$ & $94.1(2.7)$ \\
Forest fallow & $3.3(0.3) \mathrm{ab}$ & $0.30(0.02) \mathrm{ab}$ & $72.8(3.4) \mathrm{a}$ & $1.6(0.9) \mathrm{a}$ & $97.2(1.1)$ \\
Agroforest & $2.5(0.3) \mathrm{b}$ & $0.23(0.03) \mathrm{b}$ & $73.5(1.7) \mathrm{a}$ & $1.2(0.6) \mathrm{a}$ & $96.8(0.8)$ \\
Maize field & $2.8(0.2) \mathrm{b}$ & $0.25(0.02) \mathrm{b}$ & $71.1(1.9) \mathrm{a}$ & $2.4(0.7) \mathrm{a}$ & $96.4(0.8)$ \\
Grass fallow & $3.3(0.4) \mathrm{ab}$ & $0.25(0.02) \mathrm{b}$ & $44.0(10.5) \mathrm{b}$ & $24.6(12.0) \mathrm{b}$ & $59.9(11.2)$ \\
& & & $30-40 \mathrm{~cm}$ & & & \\
Natural forest & $1.1(0.2)$ & $0.11(0.01)$ & $42.0(6.4) \mathrm{ab}$ & $28.7(6.4) \mathrm{ab}$ & $67.0(6.8) \mathrm{ab}$ \\
Forest fallow & $1.0(0.1)$ & $0.09(0.01)$ & $57.4(6.5) \mathrm{ab}$ & $13.9(6.0) \mathrm{a}$ & $83.2(6.2) \mathrm{a}$ \\
Agroforest & $0.8(0.1)$ & $0.08(0.01)$ & $63.9(4.1) \mathrm{a}$ & $8.2(3.4) \mathrm{a}$ & $89.0(3.7) \mathrm{a}$ \\
Maize field & $0.8(0.1)$ & $0.08(0.01)$ & $55.8(3.9) \mathrm{ab}$ & $18.1(4.1) \mathrm{a}$ & $78.8(4.4) \mathrm{a}$ \\
Grass fallow & $1.2(0.2)$ & $0.10(0.01)$ & $33.0(10.8) \mathrm{b}$ & $46.7(10.9) \mathrm{b}$ & $47.0(12.4) \mathrm{b}$ \\
\hline
\end{tabular}


Table 9. Pearson's correlations coefficients between soil nutrient stocks, nutrient concentrations, $\mathrm{Ca}, \mathrm{K}$ and $\mathrm{Mg}$ saturation of ECEC, $\mathrm{pH}, \mathrm{BD}, \mathrm{BS}$ and ECEC (standardised values) with duration of cultivation in maize and agroforestry sites ( $r=$ correlation coefficient and $P=$ significance level)

\begin{tabular}{lcccccccc}
\hline & \multicolumn{3}{c}{$0-10 \mathrm{~cm}$ depth } & \multicolumn{3}{c}{$30-40 \mathrm{~cm}$ depth } \\
& \multicolumn{1}{c}{ Agroforestry } & \multicolumn{2}{c}{ Maize } & \multicolumn{2}{c}{ Agroforestry } & \multicolumn{2}{c}{ Maize } \\
& $r$ & $P$ & $r$ & $P$ & $r$ & $P$ & $r$ & $P$ \\
\hline C stocks & 0.21 & 0.45 & -0.44 & $\mathbf{0 . 0 2}$ & -0.11 & 0.71 & -0.22 & 0.26 \\
C \% & 0.27 & 0.33 & -0.47 & $\mathbf{0 . 0 1}$ & -0.06 & 0.85 & -0.24 & 0.23 \\
N stocks & 0.17 & 0.53 & -0.28 & 0.15 & -0.03 & 0.92 & 0.01 & 0.96 \\
N \% & 0.25 & 0.36 & -0.38 & $\mathbf{0 . 0 4}$ & 0.03 & 0.91 & -0.01 & 0.96 \\
P stocks & 0.12 & 0.68 & 0.36 & 0.06 & 0.18 & 0.55 & 0.33 & 0.08 \\
pH KCl & -0.43 & 0.11 & -0.11 & 0.56 & 0.46 & 0.10 & 0.31 & 0.12 \\
ECEC & 0.52 & $\mathbf{0 . 0 4}$ & -0.05 & 0.76 & 0.03 & 0.93 & -0.05 & 0.81 \\
Ca & 0.08 & 0.77 & 0.05 & 0.78 & 0.61 & $\mathbf{0 . 0 2}$ & 0.55 & $\mathbf{0 . 0 0 3}$ \\
K & -0.33 & 0.22 & -0.52 & $\mathbf{0 . 0 0 4}$ & -0.11 & 0.71 & -0.12 & 0.54 \\
Mg & 0.08 & 0.77 & 0.05 & 0.79 & 0.16 & 0.59 & -0.10 & 0.60 \\
BS & 0.28 & 0.31 & 0.00 & 0.99 & 0.39 & 0.17 & 0.35 & 0.07 \\
BD & -0.16 & 0.57 & 0.42 & $\mathbf{0 . 0 3}$ & -0.13 & 0.67 & 0.18 & 0.37 \\
\hline
\end{tabular}



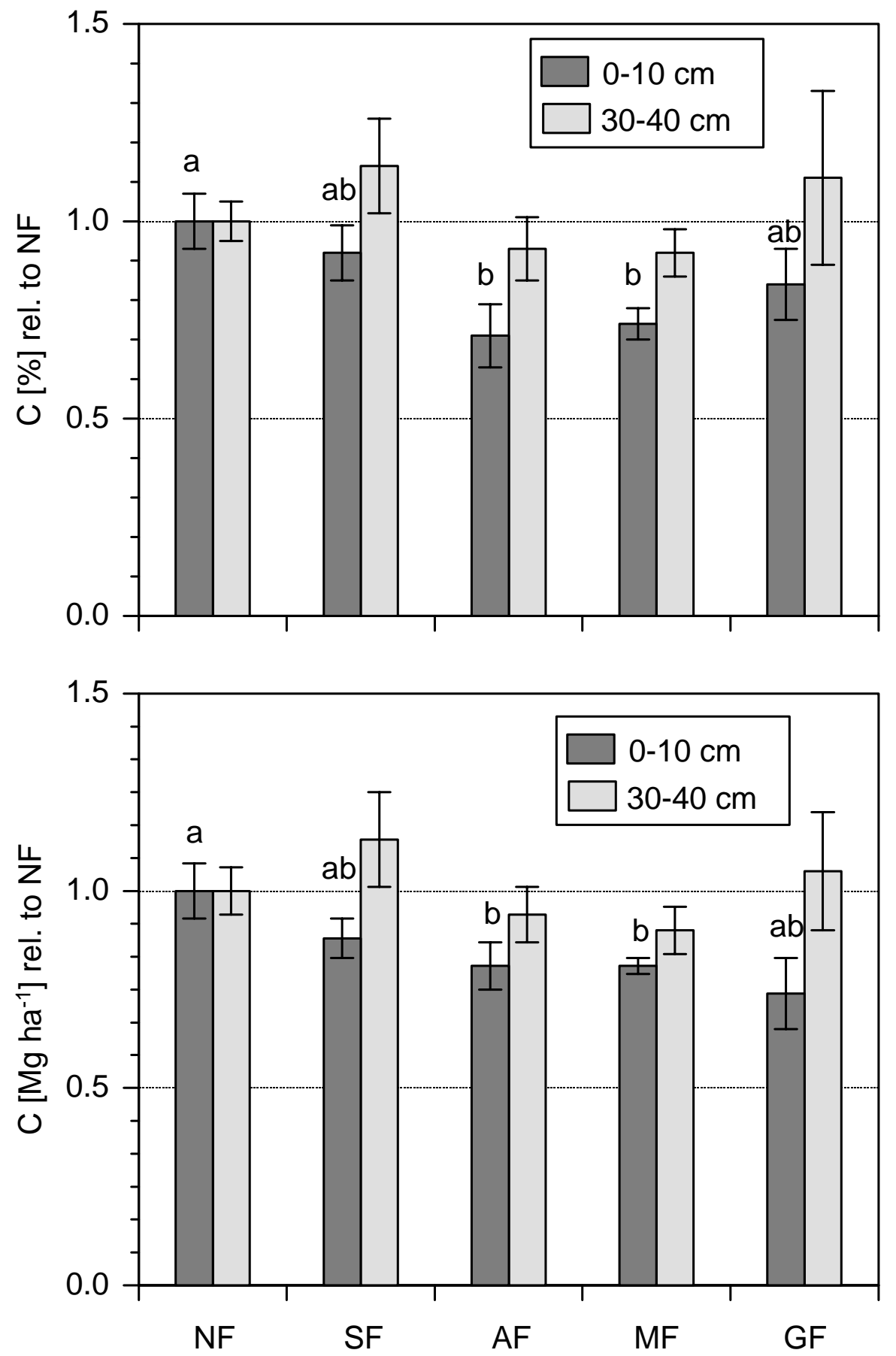

Figure 3. Soil C concentrations and soil C stocks in different land use systems, standardised values (forest $=1$ ), means and SE. Different letters indicate statistically significant differences between land use systems (one way ANOVA, Tukey’s means separation, $P<0.05$ ) 

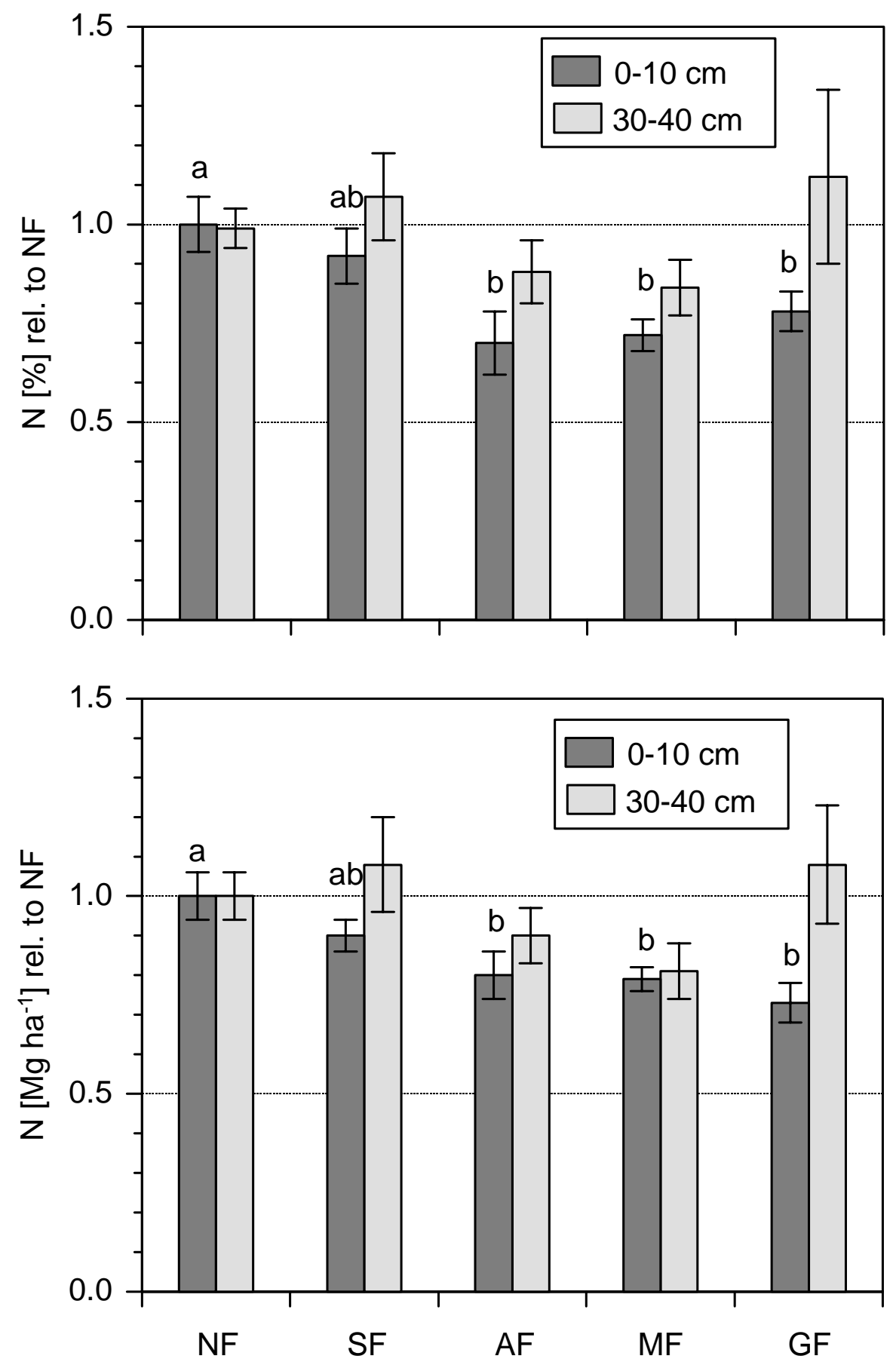

Figure 4. Soil N concentrations and soil N stocks in different land use systems, standardised values (forest $=1$ ), means and SE. Different letters indicate statistically significant differences between land use systems (one way ANOVA, Tukey’s means separation, $P<0.05$ ) 

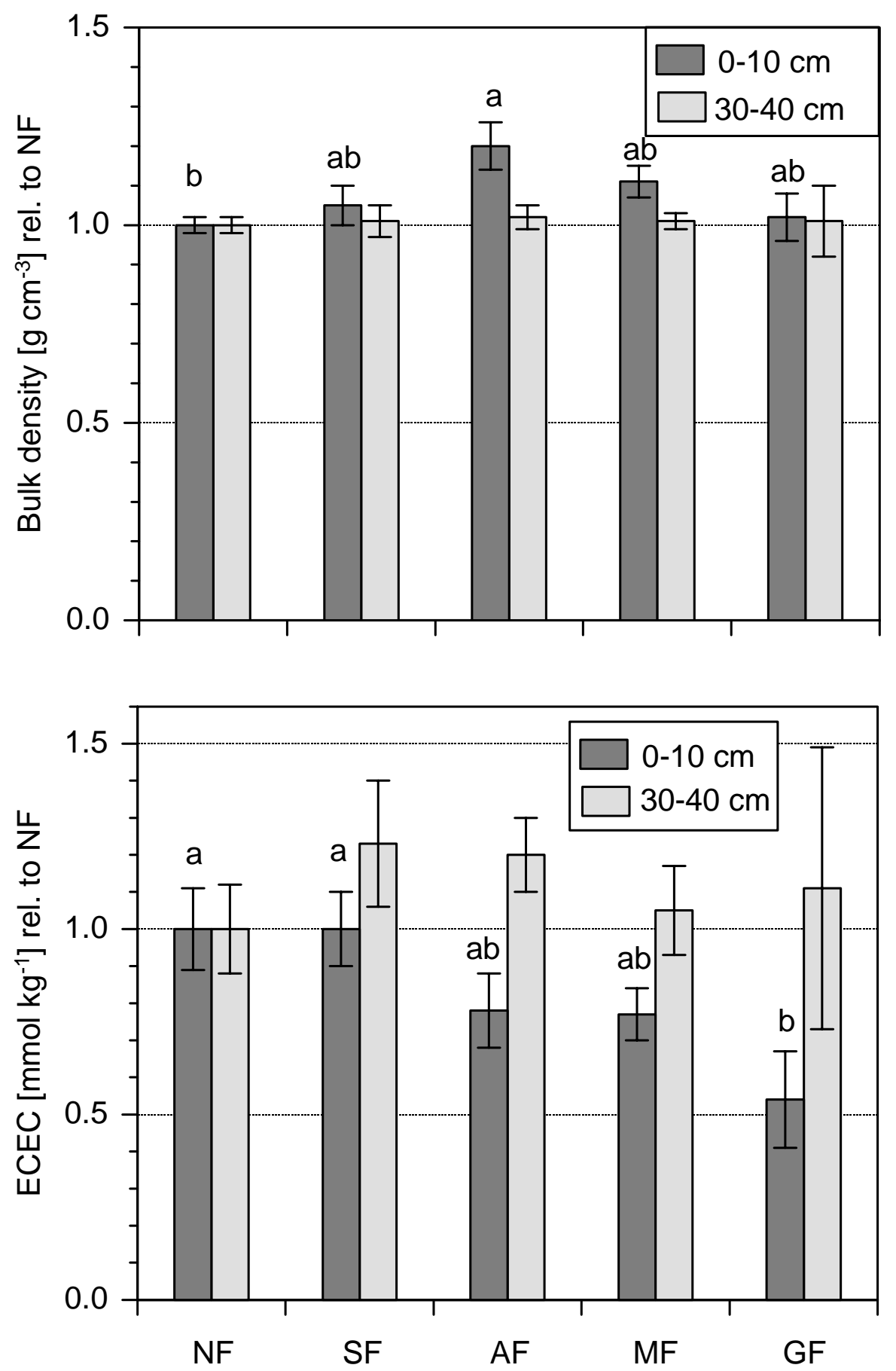

Figure 5. Soil bulk density and ECEC in different land use systems, standardised values (forest $=1$ ), means and SE. Different letters indicate statistically significant differences between land use systems (one way ANOVA, Tukey’s means separation, $P<0.05$ ) 

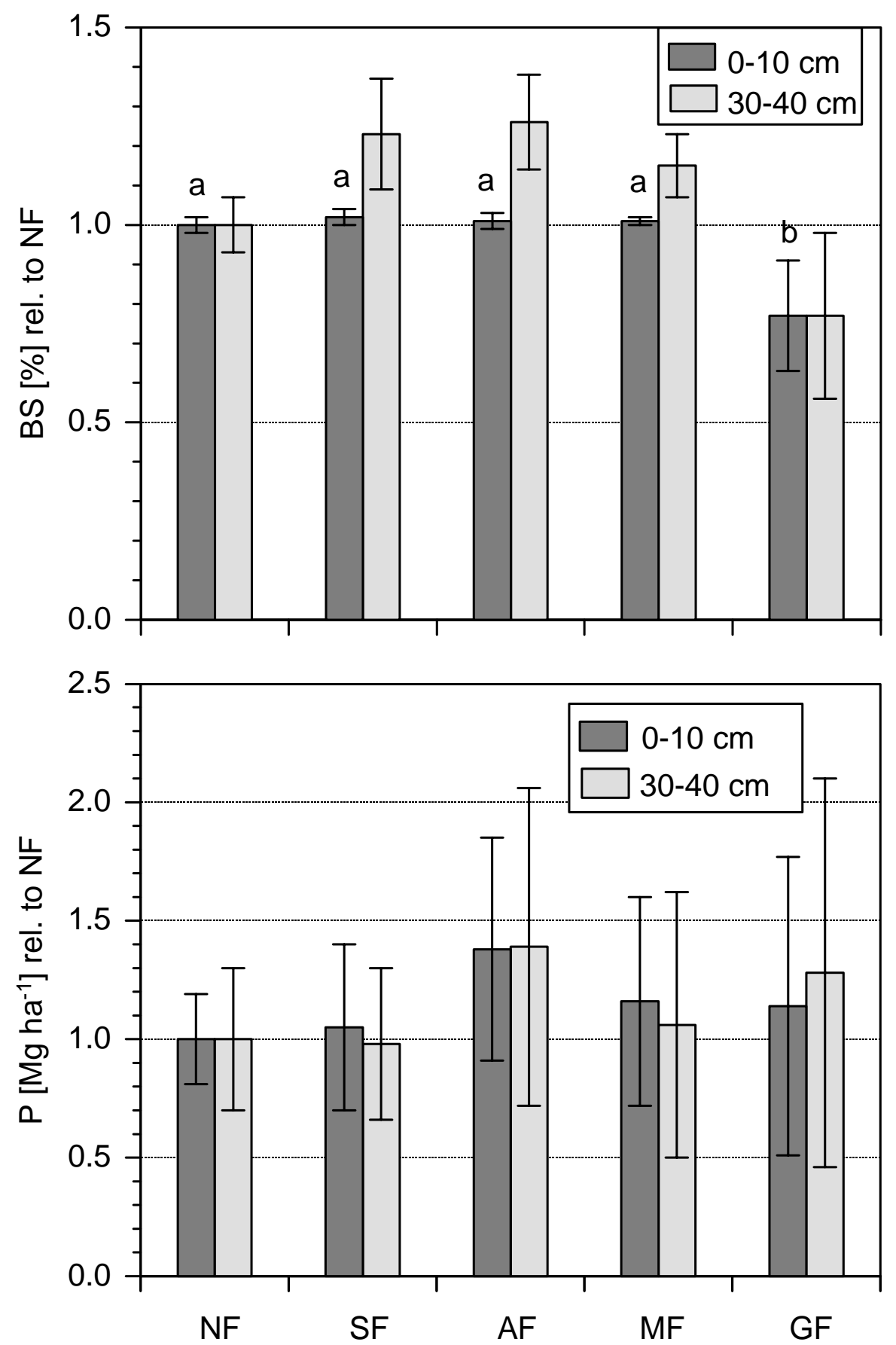

Figure 6. Base cation saturation and total $\mathrm{P}$ stocks in different land use systems, standardised values (forest $=1$ ), means and SE. Different letters indicate statistically significant differences between land use systems (one way ANOVA, Tukey’s means separation, $P<0.05$ ) 

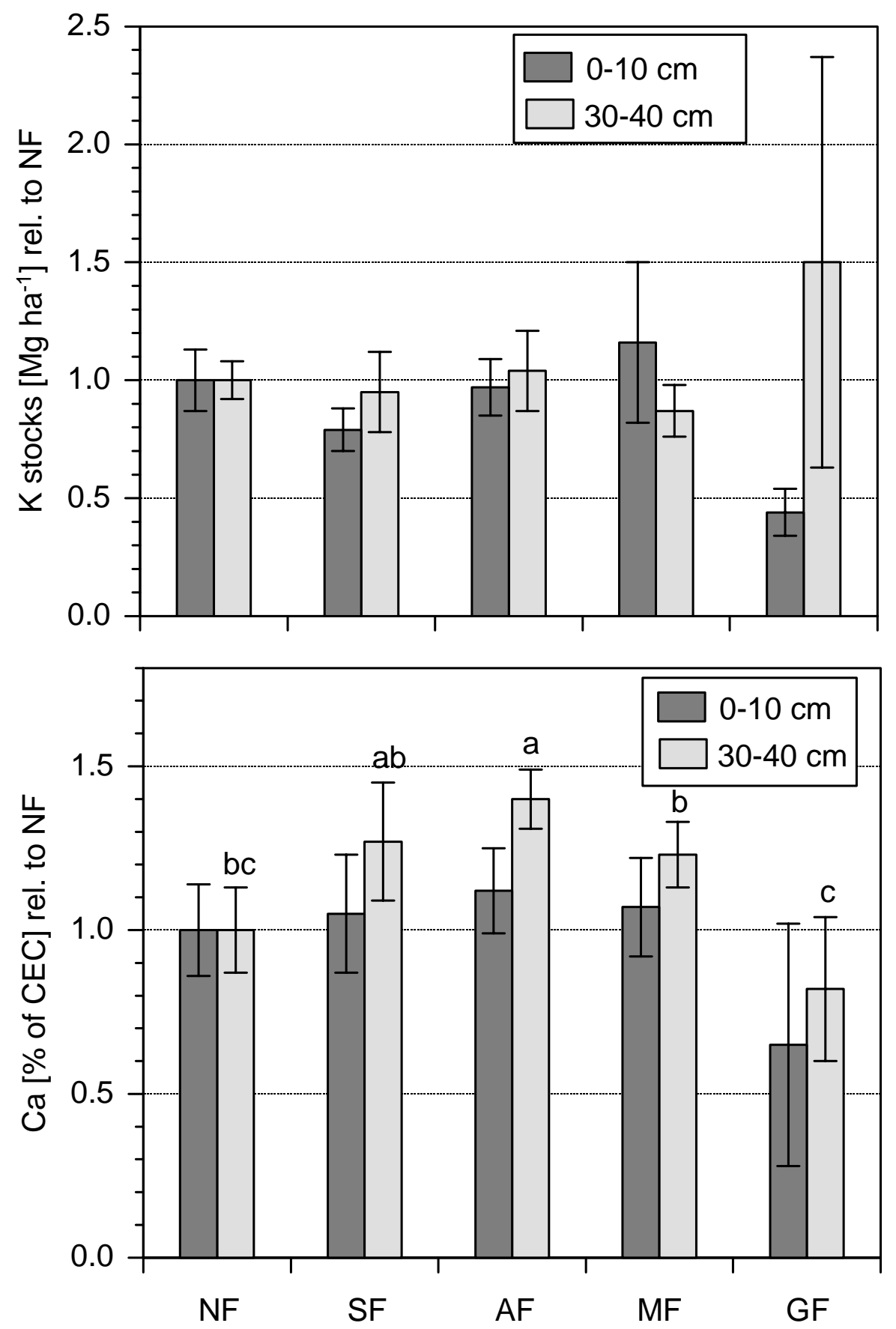

Figure 7. K stocks, and Ca saturation of ECEC in different land use systems, standardised values (forest $=1$ ), means and SE. Different letters indicate statistically significant differences between land use systems (one way ANOVA, Tukey’s means separation, $P<0.05$ ) 
Maize
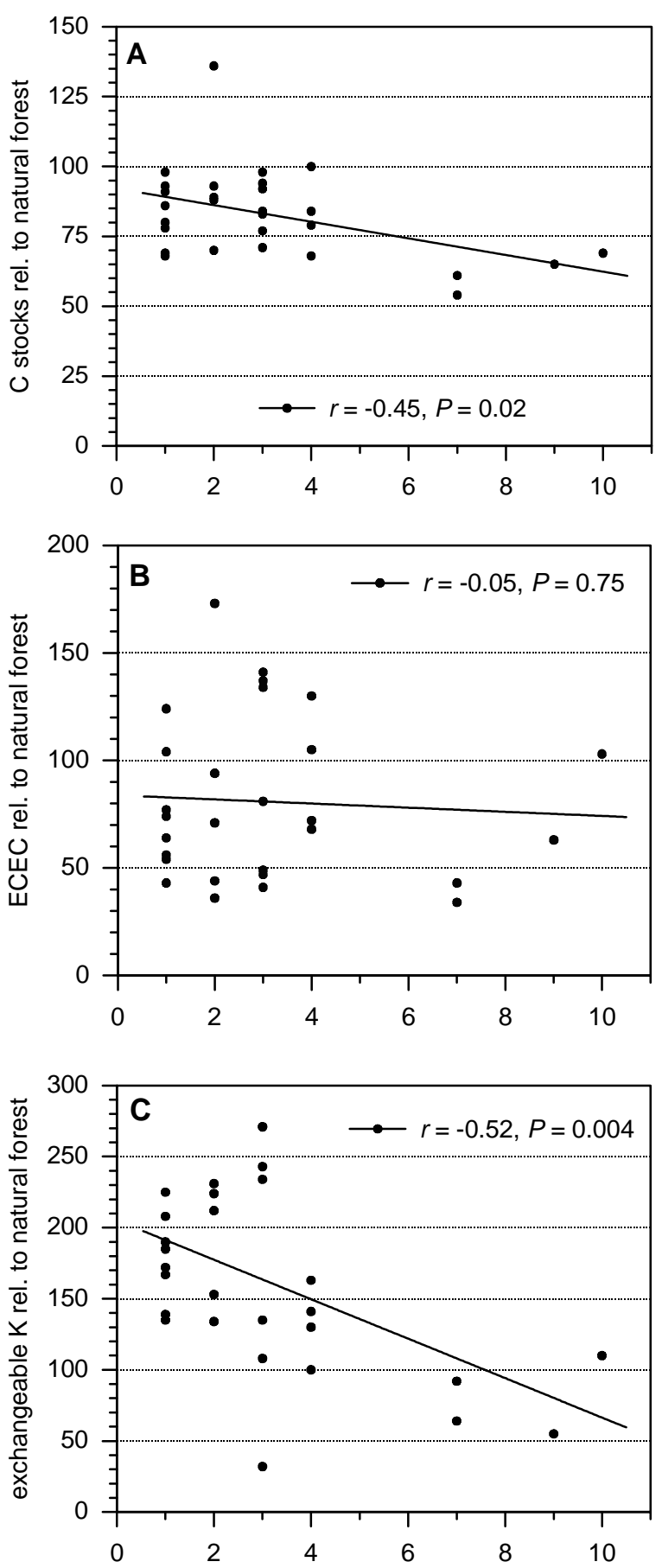

Agroforestry
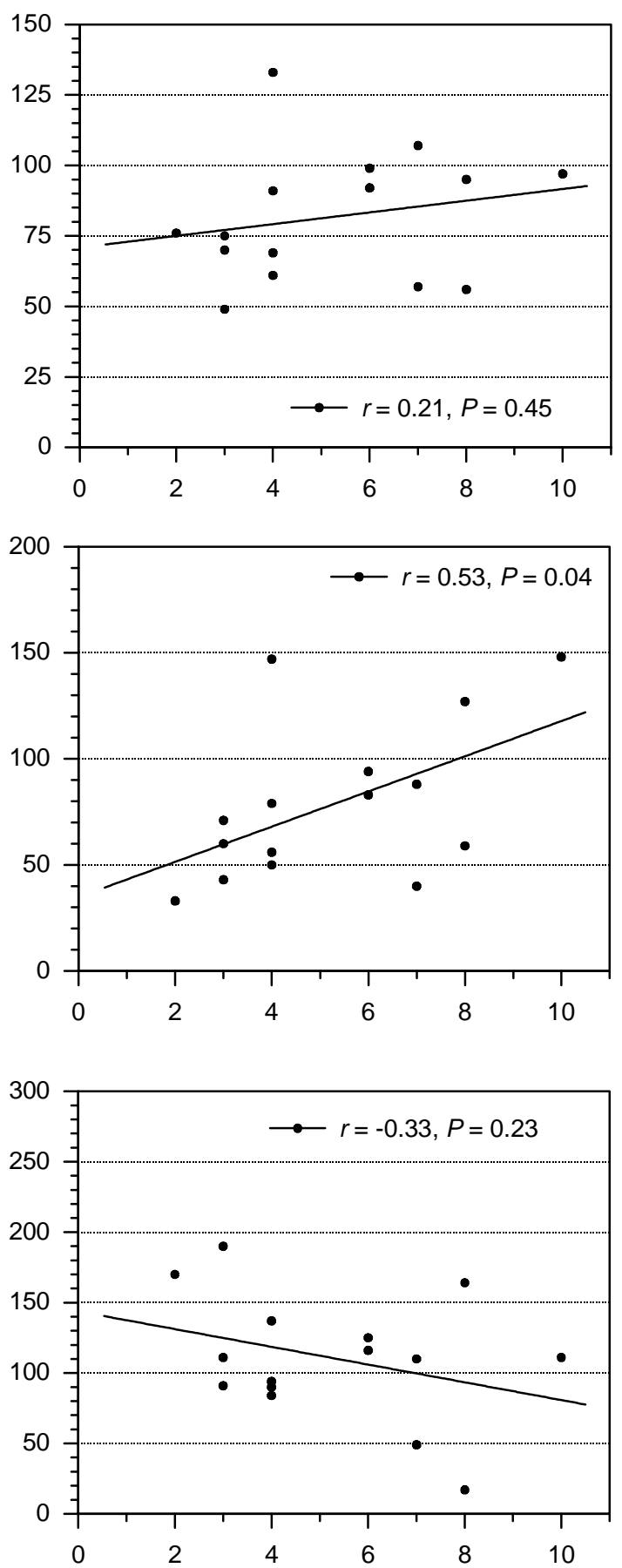

Years of cultivation

Figure 8. Relation between duration of cultivation and topsoil $(0-10 \mathrm{~cm}) \mathrm{C}$ stocks (a), ECEC (b), and exchangeable K (c), in agroforestry and maize. All values were standardized in relation to natural forest on the same soil type (natural forest $=100$ ). 


\subsection{Discussion}

\subsubsection{Effects of land use on soil $\mathrm{C}, \mathrm{N}$ and $\mathrm{P}$}

Measured $\mathrm{C}$ and $\mathrm{N}$ losses following forest clearing for agriculture were lower than the losses reported by Guo and Gifford (2002), who did a meta-analysis covering 74 publications studying the conversion of forest to crop-land. They found an average decline of soil carbon of 40-50 \% (0-60 cm depth). Similar results were reported by Schlesinger (1986), Davidson et al. (1993), and in a review of studies from Amazonia by Mc Grath et al. (2001). A possible explanation for the relatively low decrease in soil $\mathrm{C}$ and $\mathrm{N}$ following cultivation may be that most sites in this study sites were relatively young (maize: maximally 10 years old, median 3 years; and agroforestry: maximally 10 years old, median 4 years). This is because after some years of maize cultivation, farmers tend to switch to cultivation of perennial crops, and also due to recent immigration to the area and heavy forest clearing activity in the past 5-6 years. Soils may still have nutrient and especially carbon stocks for several years following clearing, but carbon and nutrient stocks will decline further with time. Especially maize fields were almost all younger than 10 years and therefore the parameters measured in these soils may not represent findings from soils which have been under cultivation for a long time. Together with the organic matter losses, bulk density increased in managed systems. The decrease in soil $\mathrm{C}$ and $\mathrm{N}$ concentrations was therefore stronger than the decrease in $\mathrm{C}$ and $\mathrm{N}$ stocks, a phenomena which must be considered when estimating changes in soil parameter caused by land use change (Veldkamp 1994).

The decline in $\mathrm{C}$ and $\mathrm{N}$ in maize fields with increasing duration of cultivation (Table 6) and the tendency of ECEC to decrease (not significant) has not always been reported. Contrary to this study, several studies have found no significant decline in $\mathrm{C}$ and $\mathrm{N}$ stocks after conversion of rain forest. Conversion to pasture may lead to both decreases and increases in soil organic matter (e.g. Hughes et al. 2000, Kauffman et al. 1998 and Veldkamp, in press). Decrease or increase of soil organic $\mathrm{C}$ and $\mathrm{N}$ under pastures has been linked to the productivity and management of pastures (e.g. Post et al. 2000, Fisher et al. 1994). Klinge (1998) studied clearing of a secondary fallow forest in a rotation system, which had probably reached a new steady state of C-stocks on a lower level than the original natural forest. Finally, Schroth et al. (2002) measured changes of C following forest conversion in the top 
$0.3 \mathrm{~m}$ of the soil profile, but no significant changes in the soil profile at greater depth (down to $2 \mathrm{~m})$.

Although in agroforestry systems soil $\mathrm{C}$ and $\mathrm{N}$ were significantly lower than in natural forests, these levels did not decrease in time but were stable or had the tendency to increase (Table 6, not significant). In the study area, agroforestry systems are often established on fields previously used for maize cultivation, which are depleted in soil C after some years of maize cultivation. Results of this study indicate that the agroforestry systems can stop the decrease in soil organic matter and they may even be able to reverse the trend. The ability of perennial crop vegetation to reverse the negative impact of forest conversion was also reported by Post et al. (2000). This has not always been reported. Other studies have found both decreases and increases of soil $\mathrm{C}$ in perennial land use systems with cocoa or oil palm (review by Schroth et al. 2001).

Significant differences of total $\mathrm{P}$ between land use systems or in the chronosequence of maize or agroforestry were not found. Managed sites tended to have higher P stocks than natural forests, but these differences disappeared when bulk density was taken into account. In a detailed study in Borneo, Lawrence et al. (2001) did not find a decrease of total P in 200 years of shifting cultivation chronosequence, but changes were found in more labile P fractions.

\subsubsection{Effects of land use on base cations}

Although K saturation of the ECEC was not significantly different in converted sites compared to natural forests, the chronosequence study revealed a fast decline of high $\mathrm{K}$ saturation in young maize fields, to much lower levels in older fields ( $>4$ years continuous cultivation). This pattern was probably caused by the high input of wood-ash on freshly opened and burned sites, followed by leaching and harvest export of $\mathrm{K}$ during maize cultivation. In agroforestry, K-saturation did not change with time and was stable on a slightly higher level than under natural forest. Contrary to the exchangeable $\mathrm{K}$, total soil $\mathrm{K}$ stocks were not differences between land uses or in the time series.

Although Ca-saturation of ECEC did not change in the topsoil, an increase of Ca saturation and base saturation with time was found at 30-40 cm depth in both land-use systems. Furthermore, Ca and Mg stocks were higher in converted systems compared to forest. The higher $\mathrm{Ca}$ and Mg stocks are probably the result of burning of above-ground biomass-stocks, resulting in high input of bases through ashes. In time the Ca cations are leached to lower 
parts of the soil profile, explaining the increase in Ca saturation. Similar results were found by Klinge (1998) who reported increases in $\mathrm{pH}$ after clearing in Amazonia. Reiners et al. (1994) and Kauffman et al. (1998) reported increase of Ca- stocks and base saturation in pasture-soils compared to forests. In their review of 100 studies in Amazonia Mc Grath et al. (2001) concluded that conversion of forest to slash and burn agriculture lead to increased $\mathrm{pH}$, bulk density and Ca saturation of ECEC.

The effect of increasing Ca saturation with time in agroforestry systems cannot be explained by ash-input through burning alone. Burning of biomass will raise $\mathrm{pH}$ and base cation concentration of the soil, and burning of harvest residuals may be responsible for this accumulative effect in maize. However, in agroforestry burning is not part of the management. The increased values compared to natural forest are the result of initial burning, but the continuing increase with time seems to be the effect of an ongoing process. One hypothesis that may explain this increase is the "nutrient pumping” effect of deep rooting crop- and shade trees in agroforestry systems: leaf litter and frequent cutting of crop- shade trees and weeds bring nutrients to the soil which were taken from deeper soil layers by the tree-roots. However, the scale of this effect remains largely unknown (Sommer 2000).

In this study on soils with moderate $\mathrm{pH}$ and high reserves of base cations no significant changes of $\mathrm{pH}$ were detected with time and land use systems did not show differences in $\mathrm{pH}$.

\subsubsection{Effect of soil fertility on the stability of forest margins}

This study demonstrates that relatively fertile soils dominate the region. Farmers reported during interviews that systematical use of fallow periods to maintain soil fertility had been practised in earlier times in some villages, but presently most plots were under permanent cultivation. Newly cleared land is normally converted to perennial plantations (cocoa and coffee) after a few years of maize culture. Maize was reportedly grown up to max. 8 times without fertiliser input or fallow period with still reasonable harvests (about 1 ton ha ${ }^{-1}$ ). Strongly degraded soils which only support a short cropping period were rare. Only grassfallows (in some cases, but not all dominated by Imperata cylindrica) showed higher Alsaturation of ECEC, low ECEC and $\mathrm{pH}$, but it was not clear if these sites were the result of degradation by agriculture, because some of these poor grasslands had reportedly never been cultivated before. Some grassland sites were clearly on previously cultivated land, others were 
still used for maize cultivation and some parts were used for cattle grazing, but large areas remained unused.

Although declining soil $\mathrm{C}$ and $\mathrm{N}$-stocks following conversion were measured, no decreases in cation-stocks with the exception of Potassium were found. Base saturation actually increased after forest clearing. The change after some years of annual maize-culture to agroforestry may be an adaptation of the farmers to reduced C- and N-stocks and ECEC in maize as agroforestry seems to stabilise the soil parameters and may even accumulate $\mathrm{C}$ and $\mathrm{N}$ in time. However, nutrient losses following conversion do not always indicate unsustainable soil use, but may indicate that the system equilibrates on a lower level, which is stable again (Schroth et al. 2001). This may be the case for the agroforestry systems in this research area with legume shade trees. From soil-conservation perspective data of this study suggest that agroforestry are a sustainable land-use system in the study area. C, N and ECEC are significantly lower than the natural forest situation, but they seem to stay stable in time.

Continuous maize culture without addition of nutrients is not sustainable in long-term perspective. To increase sustainability of maize production management should focus on maintaining and preserving soil organic matter. This could be achieved by reducing the burning of biomass after harvest and by increasing the input of organic material (e.g. manure, etc). However, if burning is reduced, the positive effect of burning on weed reduction must be supplemented by other methods, which may turn out to be too expensive. Another measure to improve the sustainability of maize cultivation could be the inclusion of legumes in the rotation cycle, which was actually observed on some farms. 


\subsection{Conclusions}

This study does not support the hypothesis that ongoing forest conversion is caused by soil degradation. Heavily degraded soils are rare in the research region. Agroforestry systems are relatively stable, at least in the age-classes that were investigated in this study, whereas during maize cultivation soil quality declines. Maize was mostly grown for a short period of time before perennials were planted. The conclusion from this study is that ongoing forest clearing in the rainforest margin of Lore Lindu National Park was not driven by soil degradation, and must be attributed to other factors (e. g. immigration, population growth, expansion of agricultural area per farmer, etc.). The high soil quality found in the research region compared to other areas in Indonesia may actually attract migrants, who clear land and start agriculture as smallholders. 


\section{3}

\section{Gross $\mathbf{N}$ cycling activity under maize and agroforestry following rainforest conversion in Central Sulawesi, Indonesia}

\subsection{Introduction}

In tropical rainforest margin areas a major land use type is slash-and-burn agriculture without fertiliser input. These systems depend largely on nutrient storage in soil and in aboveground biomass, which is released after clearing and burning of vegetation. Because of export of nutrients through harvest and leaching and absence of fertiliser input, these agricultural systems may become easily depleted of nutrients after years of continuous cultivation (Nye and Greenland, 1963).

Indonesia has the largest tropical rainforest area in Asia, but also has high annual deforestation rates (FAO, 2001). The research region in the province of Central Sulawesi is still densely forested, but annual deforestation rates have increased dramatically in the last decade (Van Rheenen et al., 2003). The rainforest margins in upland Central Sulawesi are subject to extensive clear cutting by small landholders, and the cleared sites are used for agriculture. Most common upland non-irrigated land use systems are cocoa-coffee agroforestry and monoculture maize cultivation. Farmers do not use fertiliser on these upland sites and engage in continuous cultivation without fallow periods.

In unfertilised cultivation systems, crop yield is possibly limited by $\mathrm{N}$ availability. A considerable portion of available $\mathrm{N}$ for plant and microbial use must be provided by the microbially-mediated $\mathrm{N}$ processes in the soil. In this context microbial $\mathrm{N}$ cycling was studied in order to gain understanding of the soil $\mathrm{N}$ dynamics of these land use systems. The objective of this study was to quantify gross rates of $\mathrm{N}$ mineralisation, nitrification, and of $\mathrm{NO}_{3}{ }^{-}$and $\mathrm{NH}_{4}{ }^{+}$consumption by microbes, and microbial biomass under the dominant land use systems: natural rainforest, agroforest and continuous maize cultivation. The results provide a comparative estimate of the N-supplying capacity of the soil under the agriculture-converted rainforest, which could serve as basis for formulation of management strategies for sustainable land use. 


\subsection{Materials and Methods}

\subsubsection{Site description}

The research area was in a rainforest margin around Lore Lindu National Park in Central Sulawesi, Indonesia. The mountains surrounding the national park are still widely forested, but the valleys are rapidly converted into agricultural lands. The main crops on non-irrigated fields are maize, cocoa and/or coffee, and vegetables (including legumes and starch-tuber crops). Maize is cultivated mainly as monoculture in continuous cropping systems without fallow periods. Planting and harvesting are done manually, and weeds are controlled by hoeing, herbicides, and burning. Most farmers achieve 2-3 harvests per year. The agroforestry systems are mostly mixed stands of cocoa and coffee, with legume shade trees (Gliricidia sepium, Erythrina fusca and E. subumbrans). The soil is left undisturbed; management is mainly manual weeding and pruning of shade trees and crop trees.

Measurements were conducted on the two main land use systems, maize and agroforestry, and on the natural forest sites for comparison of a minimally disturbed situation. These land use systems were sampled in three locations. In locations 1 and 2 all three land use systems were sampled, while in location 3 only maize and natural forest were sampled. In each location the land use systems were close to each other ( $<50 \mathrm{~m}$ distance), and were located on the same soil type. Location 1 was about $2 \mathrm{~km}$ south of the village Wuasa (WGS84, 51M0200280, UTM 9841920) on a flat fluvic Cambisol (FAO, 1989) with parent material of sandy alluvial sediments at $1100 \mathrm{~m}$ elevation. Location 2 was close to the village Nopu (WGS84, 51M0175747, UTM 9868545) on a sloping (8\%) eutric Cambisol with weathered schist as parent material at $600-700 \mathrm{~m}$ elevation. Location 3 was north-east of the village Wanga (WGS84, 51M0202153, UTM 9834837) on sloping (5\%) dystric Cambisol with deeply weathered phyllite as parent material at $1100 \mathrm{~m}$ elevation. Coordinates were measured with GPS-handsets at the centers of the maize fields. Forest sites in all three locations had been minimally disturbed, with manual logging of some individual trees, but the undergrowth still intact. In location 1 the agroforestry site was about 5-6 years old and the maize field was about 3 years old; both were established on a newly cleared area from rainforest. In location 2 the agroforestry site was 7-8 years old and was established on a previously cultivated cropland, while the maize site was 1 year old and was established on an area that was newly 
cleared from forest. In location 3 the maize field had been cultivated for 9 years continuously and the previous vegetation of this site was unknown.

\subsubsection{Sampling design}

Soil sampling was conducted in May 2002. Before taking samples from the forest and agroforestry sites, the litter was removed. The litter-layer in forest sites was about 5-6 cm and in agroforestry 2-3 cm of slightly decomposed leaves. In the forest sites samples were taken between the trees to avoid influences of stem flow or roots. On each site undisturbed topsoil samples $(0-5 \mathrm{~cm})$ were taken with stainless steel cores of $8 \mathrm{~cm}$ diameter. Sixteen core samples (4 replicates with 4 core samples each) were taken per site, and additional soil samples were taken for analysis of initial mineral $\mathrm{N}$ content and other supporting soil parameters. The 4 core samples within one replicate were taken within a $30 \mathrm{~cm}$ x $30 \mathrm{~cm}$ area. The four replicates were taken along a transect across the site. The transect was about 40-60 m long, and the distance between replicates was about $10 \mathrm{~m}$. The intact core samples were transported immediately to the laboratory. They were stored for $48 \mathrm{~h}$ in the dark at $24{ }^{\circ} \mathrm{C}$ (the average soil temperature).

\subsection{3 ${ }^{15} \mathrm{~N}$ pool dilution method}

Gross rates of $\mathrm{N}$ cycling were measured using ${ }^{15} \mathrm{~N}$ pool dilution techniques. Procedure for injection, incubation, and extraction of ${ }^{15} \mathrm{~N}$ as described by Davidson et al. (1991) were followed. For each replicate, two cores were injected with $\left({ }^{15} \mathrm{NH}_{4}\right)_{2} \mathrm{SO}_{4}$ solution for measurements of gross rates of $\mathrm{N}$ mineralisation and $\mathrm{NH}_{4}{ }^{+}$consumption, and another two cores with $\mathrm{K}^{15} \mathrm{NO}_{3}$ solution for gross rates of nitrification and $\mathrm{NO}_{3}^{-}$consumption measurements. Each core received five $1 \mathrm{ml}$ injections of the solutions containing $30 \mu \mathrm{g} \mathrm{N} \mathrm{ml}$

${ }^{1}$ with $98 \%{ }^{15} \mathrm{~N}$ enrichment. This was equivalent to a rate of $0.7-1.4 \mu \mathrm{g}{ }^{15} \mathrm{~N} \mathrm{~g}^{-1}$. Injection was done using a side-port needle in 5 injection points $(1 \mathrm{ml}$ each) per core, leaving columns of the solution in the core.

Two cores (one injected with ${ }^{15} \mathrm{NH}_{4}$ and one injected with ${ }^{15} \mathrm{NO}_{3}$ ) were immediately extracted with $0.5 \mathrm{M} \mathrm{K}_{2} \mathrm{SO}_{4}$ by mixing the soil well in a plastic bag and taking a subsample for mineral 
$\mathrm{N}$ extraction (1:5 ratio of soil to extractant). Time between injection and extraction was about 10 minutes ( $T_{0}$ cores). The $T_{0}$ cores were used to correct for the reactions which occur immediately after injection. Extraction was done by shaking the samples for 1 hour and filtering the extracts through pre-washed $\left(0.5 \mathrm{M} \mathrm{K}_{2} \mathrm{SO}_{4}\right)$ filter papers. Extracts were then frozen immediately for storage. The concentrations of $\mathrm{NH}_{4}{ }^{+}$and $\mathrm{NO}_{3}{ }^{-}$in the extracts were analysed using continuous flow injection colorimetry (Cenco Instruments, Breda, Netherlands).

${ }^{15} \mathrm{~N}$ from the extracts was analysed by diffusion method as described in detail by Stark and Hart (1996). However, instead of letting the acid traps float on the solution surface, $5 \mathrm{~cm}$ wide Teflon tapes were used to encase the acidified filter discs (2 discs of $7 \mathrm{~mm}$ diameter cut from glass fiber filter paper and acidified with $20 \mu \mathrm{l}$ of $2.5 \mathrm{M} \mathrm{KHSO}_{4}$ solution) and this acid trap was placed on the mouth of the glass diffusion bottle before fastening the lid. For the ${ }^{15} \mathrm{NH}_{4}{ }^{+}$labeled samples, $50 \mathrm{ml}$ of extract was placed in a $150 \mathrm{ml}$ glass bottle. $\mathrm{MgO}$ was added to convert $\mathrm{NH}_{4}{ }^{+}$to $\mathrm{NH}_{3}$, and the acid trap was immediately placed on the mouth of the bottle and the lid fastened. Diffusion proceeded for 6 days (Corre et al., 2003). For the $\mathrm{NO}_{3}{ }^{-}$-labeled samples, the bottles were left open after adding MgO for 6 days to get rid of $\mathrm{NH}_{4}{ }^{+}$, followed by a 6-day diffusion after adding Devarda's alloy to convert $\mathrm{NO}_{3}{ }^{-}$to $\mathrm{NH}_{3} \cdot{ }^{15} \mathrm{~N}$ was analysed using EA-IRMS (Finigan MAT, Bremen, Germany). Gross rates of $\mathrm{N}$ mineralisation, $\mathrm{NH}_{4}{ }^{+}$ consumption, nitrification, and $\mathrm{NO}_{3}^{-}$consumption were calculated using the modified calculation procedure of Davidson et al. (1991) from the Kirkham and Bartholomew (1954) model. Soil moisture content was determined from each soil core to express gross rates of microbial $\mathrm{N}$ cycling on soil dry mass basis.

The mean residence time (MRT) of the $\mathrm{NH}_{4}{ }^{+}$and $\mathrm{NO}_{3}{ }^{-}$pools were also determined. MRT indicates the average length of time an $\mathrm{N}$ atom resides in a given pool. This index integrates both pool size information and process rate information into one value. Hart et al. (1994) suggested that the best measure of the relative dynamics of $\mathrm{N}$ pools in the microbial $\mathrm{N}$ cycle is the MRT of that pool, where a lower MRT (faster pool turnover rate) indicates a more dynamic pool. The calculation of MRT (N pool / flux rate; e.g. $\mathrm{NH}_{4}{ }^{+}$pool MRT $=\mathrm{NH}_{4}{ }^{+}$pool / gross $\mathrm{N}$ mineralisation rate) assumed that the $\mathrm{NH}_{4}{ }^{+}$and $\mathrm{NO}_{3}{ }^{-}$pools were at steady state and that the fluxes were equal to gross rates of $\mathrm{N}$ mineralisation and nitrification, respectively. 


\subsubsection{Other supporting soil parameters}

From each replicate, soil samples from the same depth were taken and acclimatised at the same temperature and period as the cores used for microbial $\mathrm{N}$ cycling measurements. These were used for measurement of initial $\mathrm{NH}_{4}{ }^{+}$and $\mathrm{NO}_{3}{ }^{-}$concentrations (using the same extraction procedure mentioned above), and for microbial biomass $\mathrm{C}$ and $\mathrm{N}$ determination. Fumigation-extraction procedure (Brookes et al., 1985; Davidson et al., 1989) was followed for determining microbial biomass $\mathrm{C}$ and N. Two $25 \mathrm{~g}$ fresh subsamples were taken. One pair of the subsamples was immediately extracted with $0.5 \mathrm{M} \mathrm{K}_{2} \mathrm{SO}_{4}$ (approx. 5:1 ratio of solution to dry mass soil) and the other pair was fumigated for 5 days and then extracted; organic $\mathrm{C}$ and $\mathrm{N}$ were determined from the extracts. Organic $\mathrm{C}$ was analysed by UV-enhanced persulfate oxidation using a Dohrmann DC-80 Carbon Analyzer with an infrared detector (Rosemount Analytical Division, CA, U.S.A.). Organic N was determined using modified micro-Kjeldahl digestion (Corre et al., 2003). The differences in organic C and Kjeldahl $\mathrm{N}$ extracted between the fumigated and unfumigated soils ( $\mathrm{C}$ and $\mathrm{N}$ flushes) are assumed to represent the $\mathrm{C}$ and $\mathrm{N}$ released from lysed soil microbes. The $\mathrm{C}$ and $\mathrm{N}$ flushes were converted to microbial biomass $\mathrm{C}$ and $\mathrm{N}$, respectively, using $k_{\mathrm{C}}=0.45$ (Joergensen, 1996) and $k_{\mathrm{N}}=0.68$ for 5-day fumigated samples (Shen et al., 1984; Brookes et al., 1985).

Other soil characteristics were determined at the start of the study and are reported in Table 1. Total organic $\mathrm{C}$ and $\mathrm{N}$ were measured from air-dried, ground samples using CNS Elemental Analyzer (Elementar Vario EL, Hanau, Germany). Bulk density was determined using soil core method, and soil $\mathrm{pH}$ was measured from a saturated paste mixture (1:1 ratio of soil to 1 $\mathrm{M} \mathrm{KCl}$ ). Base saturation was determined from air-dried, $2 \mathrm{~mm}$ sieved samples, percolated with $1 \mathrm{M} \mathrm{NH}_{4} \mathrm{Cl}$, and the percolates were analysed for exchangeable cations using FlameAtomic Absorption Spectrometer (Varian, Darmstadt, Germany).

\section{2. 5 Statistical analyses}

First, effects of land use types at each location were tested. A study on gross rates of microbial $\mathrm{N}$ cycle showed that sampling points at $10 \mathrm{~m}$ apart were spatially independent (Corre et al., 2002). Given this information, it was assumed that sampling points (10 m apart) were spatially independent and were considered replicates in the succeeding analysis. 
Analysis was carried out for each location using one-way ANOVA, and the multiple comparisons of treatment (land use systems) effects were conducted using Least Significant Difference test at $P \leq 0.05$. Second, land use effects were tested across locations, location effects (encompassing both soil and cultivation duration differences), and land use $\mathrm{x}$ location interaction using GLM General Factorial analysis. Sampling points (replications), which were nested within land use type, were treated as a random effect, while all other effects (land use type, location, and land use $\mathrm{x}$ location) were treated as fixed effects. Type III sums of squares were computed for fixed effects. Multiple comparisons of fixed effect least square means were conducted using Least Significant Difference test at $P \leq 0.05$. Means and standard errors were reported as measures of central tendency and dispersion.

\subsection{Results}

Higher extractable $\mathrm{NH}_{4}{ }^{+}$than extractable $\mathrm{NO}_{3}{ }^{-}$were observed in all sites (Fig. 7A). Such trends were similar to the unfertilised land use systems in temperate areas (e.g. Davidson et al., 1990; Stienstra et al., 1994; Corre et al., 2002), and to extensively managed pastures older than 10 years in Costa Rica (Veldkamp et al., 1999), which have been claimed to be limited of available $\mathrm{N}$. Generally high $\mathrm{NH}_{4}{ }^{+}$concentrations $\left(>4 \mathrm{mg} \mathrm{kg}^{-1}\right)$ were found in the forest sites at all locations, whereas pattern for $\mathrm{NO}_{3}{ }^{-}$concentration was not as clear. $\mathrm{NO}_{3}{ }^{-}$was not detectable in the forest site of location 3, while it was high $\left(\geq 3 \mathrm{mg} \mathrm{NO}_{3}{ }^{-} \mathrm{N} \mathrm{kg}^{-1}\right)$ in the other forest sites (locations 1 and 2) and in the 1 year cultivated maize site (location 2).

On average (all land use types across locations), $37 \pm 3 \%$ of the added ${ }^{15} \mathrm{NH}_{4}{ }^{+}$was recovered in the form added when the intact cores were extracted 10 minutes $\left(\mathrm{T}_{0}\right)$ after injection of ${ }^{15} \mathrm{NH}_{4}{ }^{+}$solution (Fig. 7B). There was no difference detected in ${ }^{15} \mathrm{NH}_{4}{ }^{+}$recoveries among land use types at each location. However, ${ }^{15} \mathrm{NH}_{4}{ }^{+}$recoveries differed among locations across all land use types; higher ${ }^{15} \mathrm{NH}_{4}{ }^{+}$recoveries were observed in location $2(53 \pm 4 \%)$ than locations 1 and $3\left(21 \pm 2 \%\right.$ and $36 \pm 6 \%$, respectively). On the other hand, very low ${ }^{15} \mathrm{NO}_{3}{ }^{-}$recoveries in $\mathrm{NO}_{3}{ }^{-}$pool were measured after 10 minutes of ${ }^{15} \mathrm{NO}_{3}{ }^{-}$injection (Fig. 7B). Average ${ }^{15} \mathrm{NO}_{3}{ }^{-}$ recoveries ranged from $4 \pm 2 \%$ to $13 \pm 2 \%$ of added ${ }^{15} \mathrm{NO}_{3}{ }^{-}$, with the exception of the forest site of location 3 where neither ${ }^{15} \mathrm{NO}_{3}{ }^{-}$nor $\mathrm{NO}_{3}{ }^{-}$was detected. Rates of gross nitrification and 
$\mathrm{NO}_{3}{ }^{-}$consumption measured from $\mathrm{T}_{0}$ (10 minutes) to $\mathrm{T}_{1}$ (2 days incubation) were very low and were not significantly higher than zero (Fig. 8).

The forest and maize sites in location 2 showed comparable microbial biomass sizes, which were higher than that in agroforest site (Table 11). This maize site was established within 1 year after forest clearing while the agroforest site has been established 8 years ago. The microbial $\mathrm{C} / \mathrm{N}$ ratio in the agroforest sites in locations 1 and 2 were also higher than that in the forest and maize sites (Table 11), indicating a shift towards a more fungal-dominated microbial population in the agroforest sites (Paul and Clark, 1989). The maize site in location 3 that was already 9 years of continuous cultivation showed lower microbial biomass size and higher microbial $\mathrm{C} / \mathrm{N}$ ratio than the reference forest site.

The agroforest site in location 1 had comparable gross $\mathrm{N}$ mineralisation rates with the reference forest site while the maize sites in both locations 1 and 3 showed the lowest gross $\mathrm{N}$ mineralisation rates (Fig. 9A). There was no difference detected in gross $\mathrm{NH}_{4}{ }^{+}$consumption rates among land use types at each location; however, these rates were closely coupled with the gross $\mathrm{N}$ mineralisation rates (Fig. 9A). The agroforest site tended to show fast turnover rate (i.e. short MRT) of $\mathrm{NH}_{4}^{+}$pool (i.e. location 1, Fig 9B), while a long-term cultivated maize site (i.e. location 3, Fig. 9B) showed the slowest turnover rate of $\mathrm{NH}_{4}{ }^{+}$pool.

Across locations, the agroforest sites had comparably high gross $\mathrm{N}$ mineralisation and $\mathrm{NH}_{4}{ }^{+}$ consumption rates with the forest sites, which were greater than the $\mathrm{NH}_{4}{ }^{+}$transformation rates in the maize sites (Table 12). This was despite the fact that the agroforest sites had the lowest microbial biomass $\mathrm{C}$ and $\mathrm{N}$ (Table 12). The specific gross $\mathrm{N}$ mineralisation rate (i.e. gross $\mathrm{N}$ mineralisation-to-microbial $\mathrm{N}$ ratio as an indicator of energy maintenance activity of the microbial biomass, e.g. chemoheterotrophs) showed the highest specific $\mathrm{N}$ mineralisation activity in the agroforest sites and the lowest specific activity in the maize sites (Table 12). The MRT of the $\mathrm{NH}_{4}{ }^{+}$pool also followed a similar pattern. Across locations, the movement of $\mathrm{NH}_{4}{ }^{+}$through the $\mathrm{NH}_{4}{ }^{+}$pool was fastest (i.e. shortest MRT) in the agroforest, which was comparable with the forest sites, and slowest (i.e. longest MRT) in the maize sites (Table 12). In general, locations 1 and 2 showed comparably higher $\mathrm{NH}_{4}{ }^{+}$cycling activity (i.e. higher gross $\mathrm{N}$ mineralisation rates, specific gross $\mathrm{N}$ mineralisation rates, and faster $\mathrm{NH}_{4}{ }^{+}$pool turnover rates) and lower microbial biomass size than location 3. It should be noted that location 3 has also lower soil $\mathrm{pH}$ and base saturation than locations 1 and 2 (Table 10). 
Table 10. Soil characteristics, means (SE).

\begin{tabular}{lcccccc}
\hline Land use & $\mathrm{C}$ & $\mathrm{N}$ & bulk density & $\mathrm{pH}$ & Base sat. & texture \\
& $\%$ & $\%$ & $\mathrm{~g} \mathrm{~cm}^{-3}$ & $\mathrm{KCl}$ & $\%$ & clay \% \\
\hline Forest & $3.8(0.4)$ & $0.37(0.02)$ & $1.12(0.03)$ & $5.8(0.6)$ & $98.9(0.8)$ & 14.4 \\
Agroforest & $3.2(0.4)$ & $0.31(0.03)$ & $1.14(0.02)$ & $5.7(0.2)$ & $99.4(0.1)$ & 13.2 \\
Maize & $4.7(0.6)$ & $0.40(0.03)$ & $1.00(0.01)$ & $6.5(0.3)$ & $99.6(0.1)$ & 15.2 \\
& & \multicolumn{7}{c}{ Location 1, fluvic cambisol } \\
Forest & $3.2(0.1)$ & $0.32(0.01)$ & $0.86(0.04)$ & $5.2(0.2)$ & $98.4(0.2)$ & 18.0 \\
Agroforest & $1.5(0.2)$ & $0.12(0.01)$ & $1.41(0.01)$ & $5.7(0.2)$ & $97.4(1.3)$ & 13.2 \\
Maize & $2.5(0.1)$ & $0.25(0.01)$ & $1.17(0.03)$ & $6.5(0.2)$ & $99.0(0.1)$ & 12.0 \\
& \multicolumn{7}{c}{ Location 3, dystric cambisol } & & \\
Forest & $5.9(0.1)$ & $0.38(0.04)$ & $0.83(0.03)$ & $4.4(0.3)$ & $69.6(12.2)$ & 59.6 \\
Maize & $4.9(0.2)$ & $0.39(0.02)$ & $0.91(0.06)$ & $4.6(0.2)$ & $80.0(13.0)$ & 38.0 \\
\hline
\end{tabular}


Table 11. Microbial biomass $\mathrm{N}$, microbial biomass $\mathrm{C}$, and microbial $\mathrm{C}$ to $\mathrm{N}$ ratio. At each location ( $\mathrm{n}=4)$, means (SE) followed by the same letter indicated no significant difference among treatments (one-way ANOVA, Least Significant Difference test at $P \leq 0.05$ ).

\begin{tabular}{llrrr}
\hline Location & Land use & microbial N & microbial C & $\begin{array}{c}\text { microbial C to N } \\
\text { ratio }\end{array}$ \\
\hline Location 1 & Forest & $205(27) \mathrm{a}$ & $2380(152) \mathrm{a}$ & $12.3(1.0) \mathrm{b}$ \\
& Agroforest & $129(4) \mathrm{a}$ & $2531(384) \mathrm{a}$ & $20.0(3.2) \mathrm{a}$ \\
& Maize & $180(8) \mathrm{a}$ & $2462(121) \mathrm{a}$ & $13.7(0.5) \mathrm{ab}$ \\
& & & & \\
Location 2 2 & Forest & $153(17) \mathrm{a}$ & $2464(176) \mathrm{ab}$ & $17.1(1.6) \mathrm{b}$ \\
& Agroforest & $71(7) \mathrm{b}$ & $1719(74) \mathrm{b}$ & $25.6(1.9) \mathrm{a}$ \\
& Maize & $220(11) \mathrm{a}$ & $2633(303) \mathrm{a}$ & $12.0(1.3) \mathrm{b}$ \\
& & & & \\
Location 3 3 & Forest & $448(21) \mathrm{a}$ & $6742(435) \mathrm{a}$ & $15.2(1.0) \mathrm{a}$ \\
& Maize & $223(6) \mathrm{b}$ & $4629(225) \mathrm{b}$ & $20.7(0.8) \mathrm{b}$ \\
\hline
\end{tabular}


Table 12. Effects of the land use type and locations (soil type and cultivation duration) on microbial $\mathrm{NH}_{4}{ }^{+}$cycling and microbial biomass C and N. Means (SE) followed by the same letter indicated no significant differences among land use types and locations (GLM General Factorial analysis, Least Significant Difference test at $P \leq 0.05$ ).

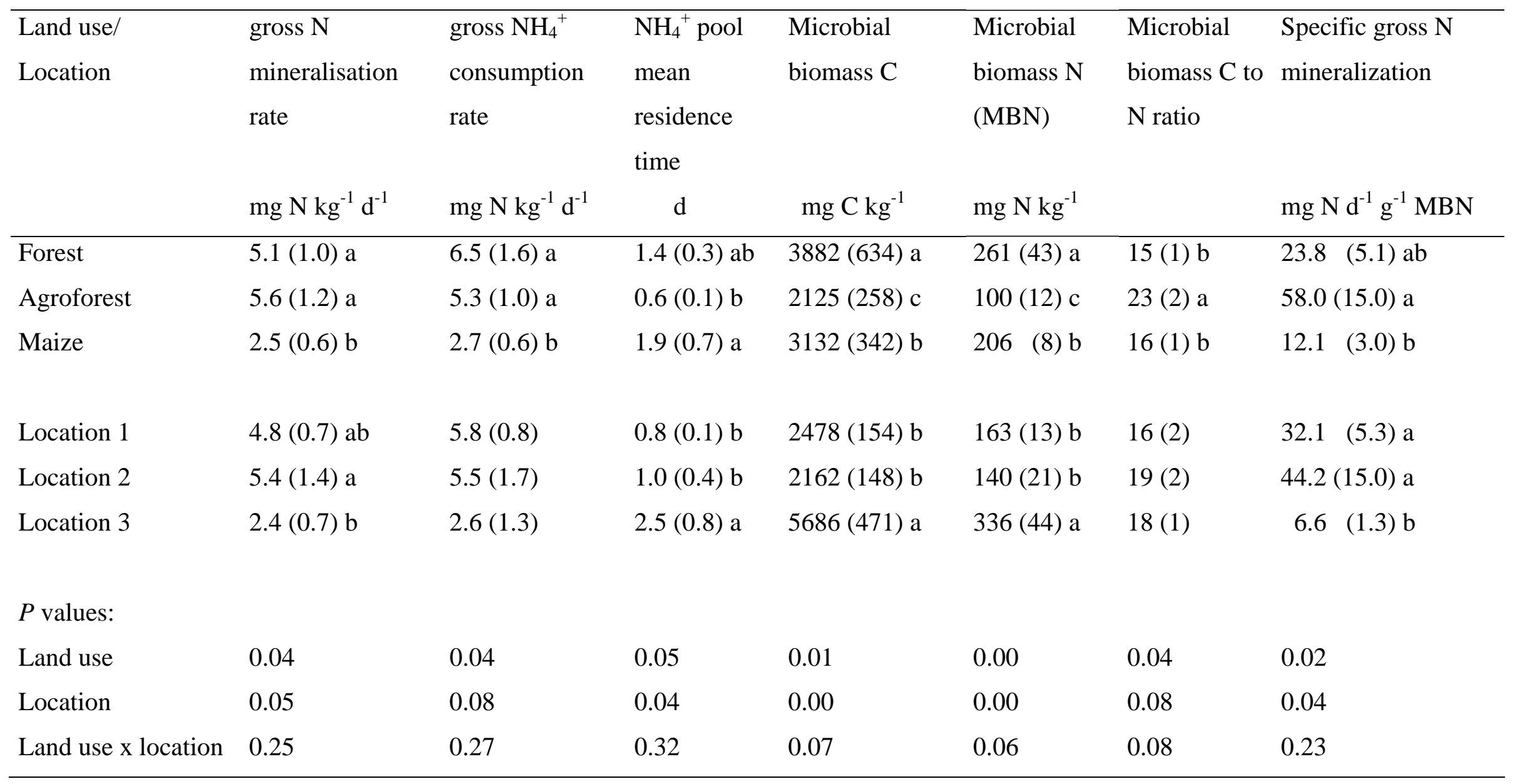



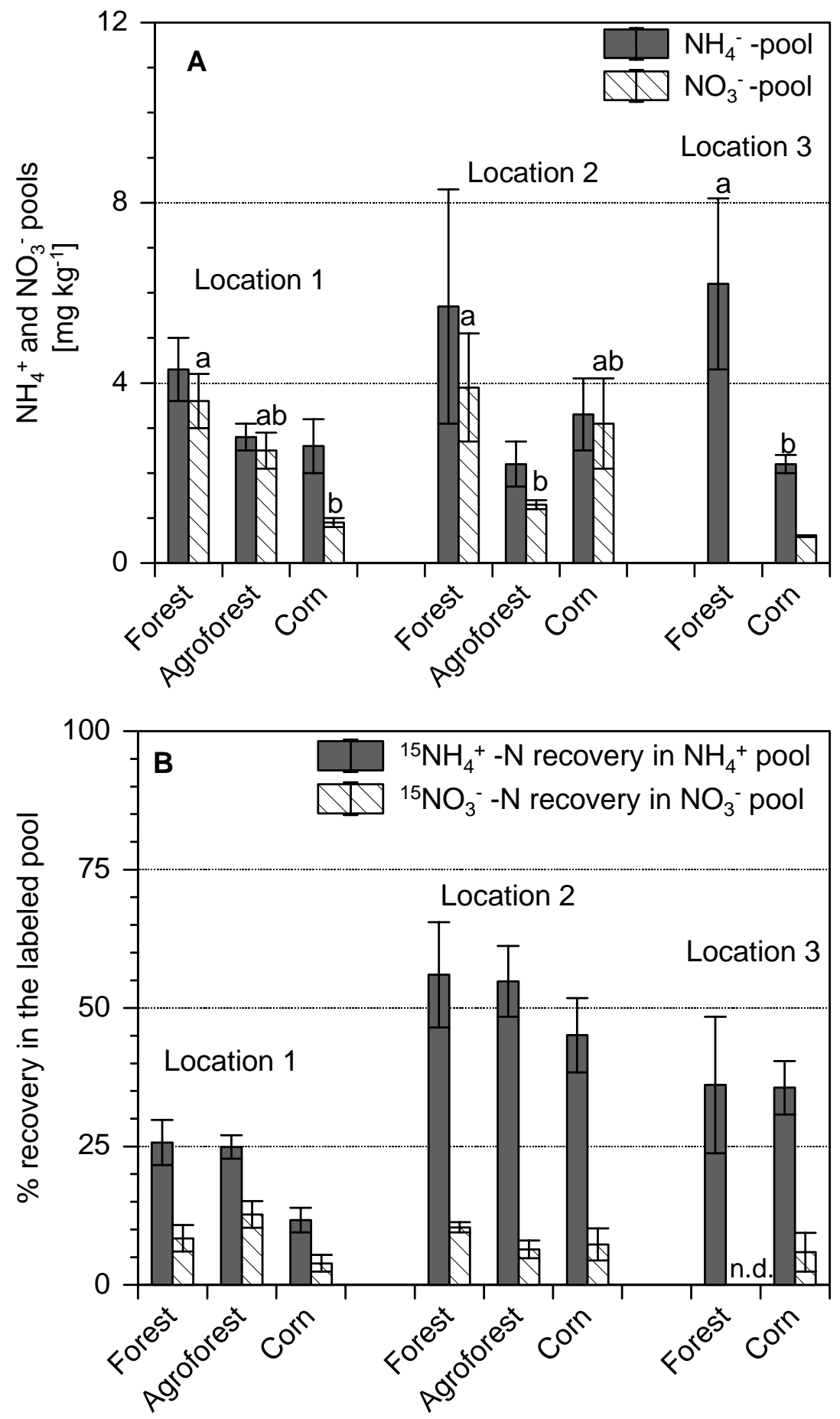

Figure 9. (A) Initial $\mathrm{NH}_{4}{ }^{+}$and $\mathrm{NO}_{3}{ }^{-}$-pools, and (B) percent ${ }^{15} \mathrm{~N}$ recovery in the labeled pools 10 minutes $\left(\mathrm{T}_{0}\right)$ after ${ }^{15} \mathrm{~N}$ injection in the intact cores. At each location $(\mathrm{n}=4)$, means $(\mathrm{SE})$ followed by the same letter indicate no significant difference among treatments (one-way ANOVA, Least Significant Difference test at $P \leq 0.05$ ). (n. d. $=\mathrm{NO}_{3}{ }^{-}$or ${ }^{15} \mathrm{NO}_{3}{ }^{-}$not detected). 


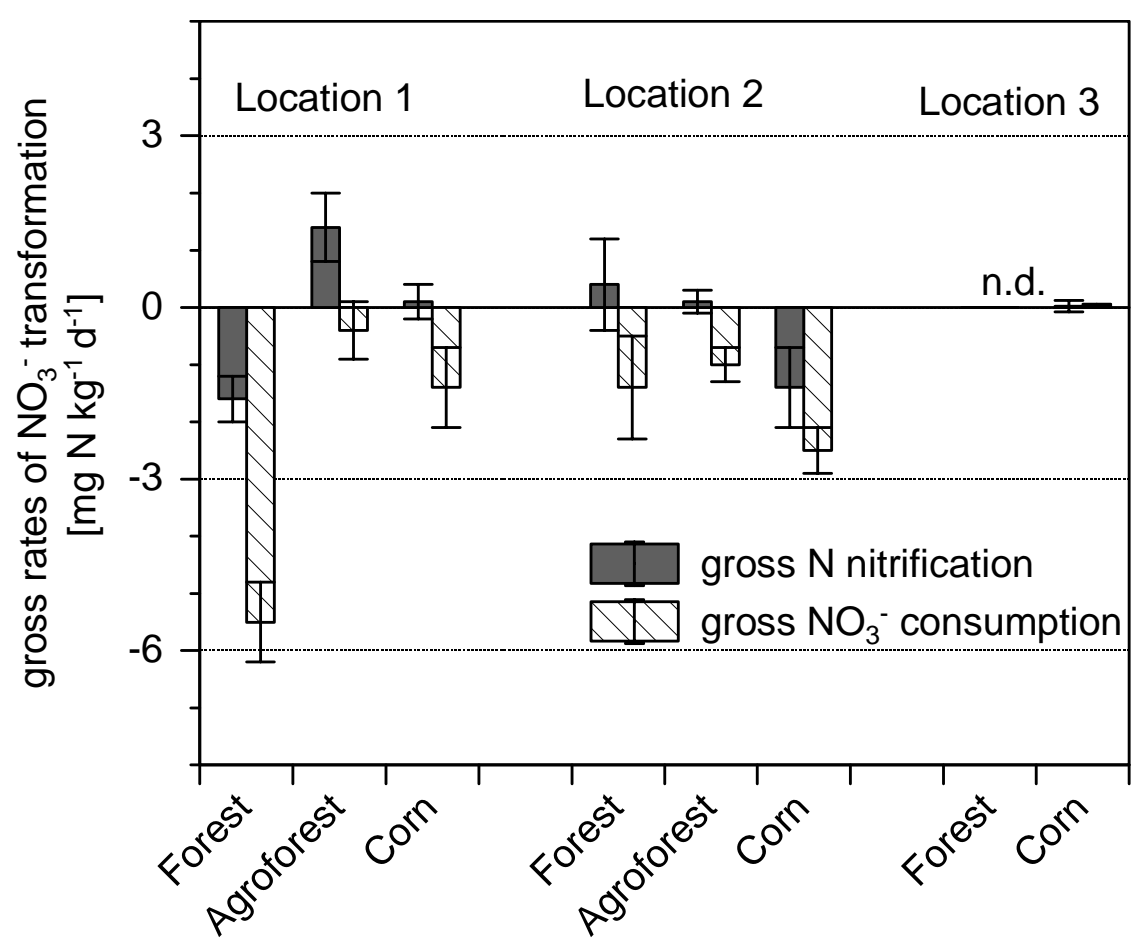

Figure 10. Gross nitrification rates and gross $\mathrm{NO}_{3}{ }^{-}$consumption rates. At each location $(\mathrm{n}=$ 4), means (SE) were not greater than zero (one sided t-test at $P \leq 0.05$; n. d. $=\mathrm{NO}_{3}{ }^{-}$or ${ }^{15} \mathrm{NO}_{3}{ }^{-}$ not detected). 

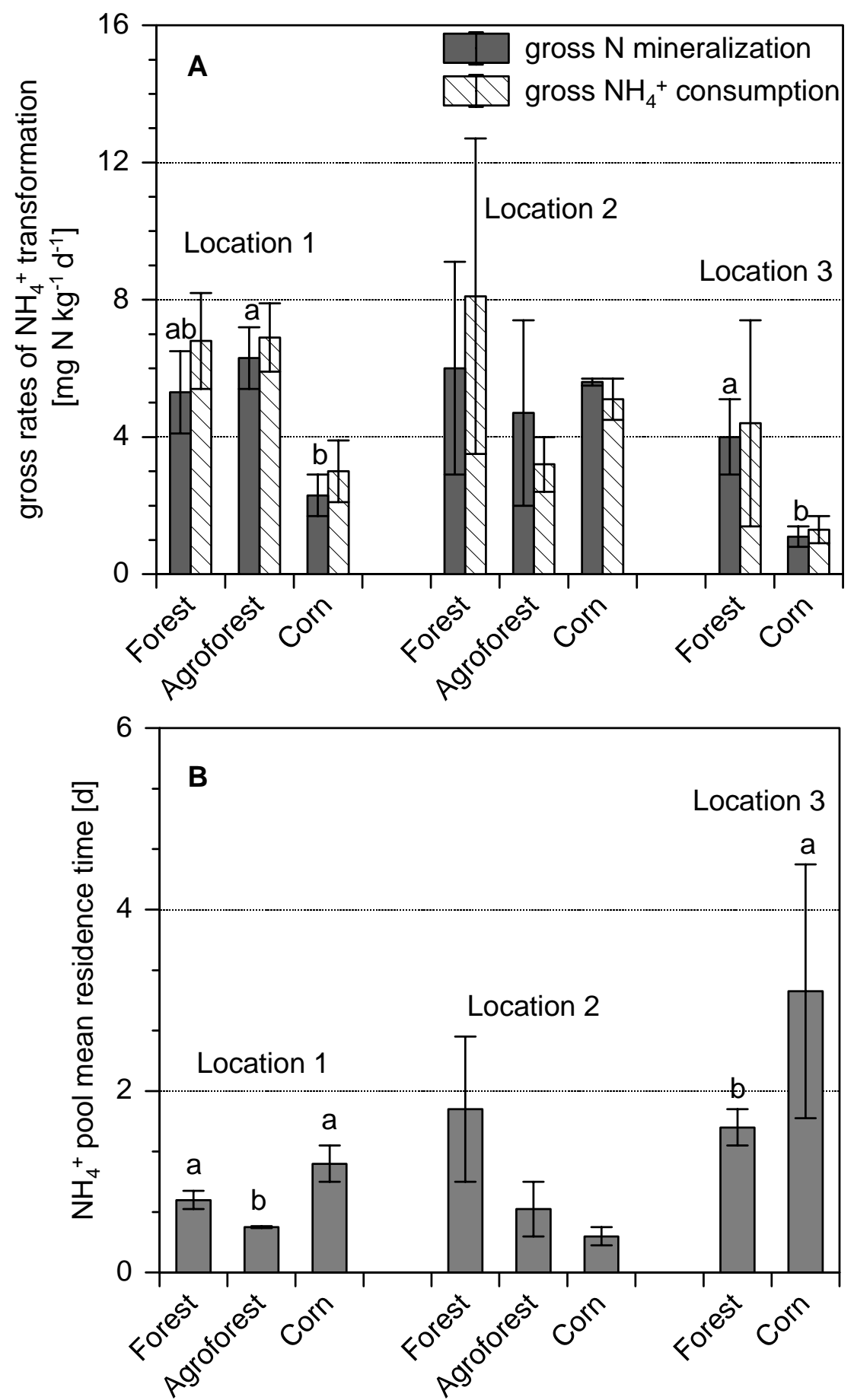

Figure 11. (A) Gross $\mathrm{N}$ mineralisation rates and gross $\mathrm{NH}_{4}^{+}$consumption rates, and (B) mean residence time of $\mathrm{NH}_{4}{ }^{+}$pool. At each location $(\mathrm{n}=4)$, means (SE) followed by the same letter indicated no significant difference among treatments (one-way ANOVA, Least Significant Difference test at $P \leq 0.05$ ) 


\subsection{Discussion}

The fast reactions (occurring within 10 minutes) of added ${ }^{15} \mathrm{NH}_{4}{ }^{+}$is usually attributed to abiotic $\mathrm{NH}_{4}^{+}$reactions (e.g. physical condensation reactions with phenolic compounds (Nömmik and Vahtras, 1982), and fixation on clay minerals in mineral soil (Davidson et al., 1991)). Abiotic incorporation of $\mathrm{NH}_{4}{ }^{+}$into organic compounds was reported to be enhanced by high $\mathrm{pH}$ (because $\mathrm{NH}_{3}$ is the reactive form of $\mathrm{N}$ ) and high $\mathrm{NH}_{4}{ }^{+}$concentration (Nömmik and Vahtras, 1982). The soil $\mathrm{pH}$ in the study sites were generally below 6.5 (Table 1), and there was no clear difference in $\mathrm{NH}_{4}{ }^{+}$concentrations among locations (Fig. 1A).

The differences in ${ }^{15} \mathrm{NH}_{4}{ }^{+}$recoveries among locations could possibly be due to the differences in clay mineralogy inherent to the differences in soil parent materials of these locations. Furthermore, higher recovery of ${ }^{15} \mathrm{NH}_{4}{ }^{+}$than of ${ }^{15} \mathrm{NO}_{3}{ }^{-}$at $\mathrm{T}_{0}$ was also found in other studies (e.g. Compton and Boone, 2002; Corre et al., 2003). Values of ${ }^{15} \mathrm{NO}_{3}{ }^{-}$recovery were in the same range with those reported by Compton and Boone (2002) from Harvard Forest, USA with differing land use history (i.e. average ${ }^{15} \mathrm{NO}_{3}{ }^{-}$recovery of $10 \%$ after 5 minutes of ${ }^{15} \mathrm{NO}_{3}{ }^{-}$ addition). They also reported zero recovery of added ${ }^{15} \mathrm{NO}_{3}{ }^{-}$from a historically cultivated conifer forest soil.

Data on gross $\mathrm{N}$ transformation rates in tropical land use systems are relatively few, and methodological differences make comparisons difficult. Garcia-Montiel and Binkley (1998) measured gross $\mathrm{N}$ transformation rates from tropical Eucalyptus (non $\mathrm{N}$-fixer) and Albizia (Nfixer) plots in Hawaii using disturbed (10 g) soil samples, and gross $\mathrm{N}$ mineralisation and nitrification were calculated without correction of the initial $\left(\mathrm{T}_{0}\right){ }^{15} \mathrm{NH}_{4}^{+}$and ${ }^{15} \mathrm{NO}_{3}{ }^{-}$ recoveries. Such calculation method could lead to overestimation of gross rates (Davidson et al., 1991). In this study measured rates of gross $\mathrm{N}$ mineralisation and nitrification were lower than those of Garcia-Montiel and Binkley (1998), but were comparable to those of Compton and Boone (2002) that were corrected with ${ }^{15} \mathrm{~N}$ recoveries at $\mathrm{T}_{0}$.

It was not possible to detect significant nitrification activity. Similar results were reported by Compton and Boone (2002) from Harvard forest, which showed low ${ }^{15} \mathrm{NO}_{3}{ }^{-}$recoveries at $\mathrm{T}_{0}$. ${ }^{15} \mathrm{NO}_{3}{ }^{-}$recoveries were measured in the $\mathrm{NO}_{3}{ }^{-}$pool after 2 days $\left(\mathrm{T}_{1}\right)$ of ${ }^{15} \mathrm{NO}_{3}{ }^{-}$injection (data not shown), and there was no significant difference detected with that at $\mathrm{T}_{0}$. This suggested that had there been $\mathrm{NO}_{3}{ }^{-}$produced during the 2-day incubation period, there might have been a very fast reaction of $\mathrm{NO}_{3}{ }^{-}$, possibly imposing added competition for the fate of $\mathrm{NO}_{3}{ }^{-}$, so that 
it was not possible to detect any change in $\mathrm{NO}_{3}{ }^{-}$pool size during the period of incubation. Recently several studies have reported the potential for some ecosystems to have significant fast (10-15 minutes after ${ }^{15} \mathrm{NO}_{3}{ }^{-}$addition) abiotic $\mathrm{NO}_{3}{ }^{-}$immobilisation (Berntson and Aber, 2000; Dail et al., 2001; Corre et al., 2003; Davidson et al., 2003). Such reaction was recognised as early as 1991 (Davidson et al., 1991), but was then considered only as a methodological 'noise' of ${ }^{15} \mathrm{~N}$ pool dilution method that necessitates correction using the initial ${ }^{15} \mathrm{NO}_{3}{ }^{-}$recovery. Recently this is considered as a possible mechanism contributing to $\mathrm{N}$ retention in an ecosystem (Davidson et al., 2003). It was not measured to which soil $\mathrm{N}$ pool the unrecovered portion of the added ${ }^{15} \mathrm{NO}_{3}{ }^{-}$at $\mathrm{T}_{0}$ was converted. Such fast reaction of added ${ }^{15} \mathrm{NO}_{3}{ }^{-}$certainly warrants further investigation, particularly in the tropical soils where ${ }^{15} \mathrm{~N}$ studies are rare.

Although the agroforest sites had the lowest microbial biomass size (which, based on the high microbial $\mathrm{C} / \mathrm{N}$ ratio, was also possibly dominated by fungal chemoheterotrophs), this microbial population was actively involved in the $\mathrm{NH}_{4}{ }^{+}$cycling. This was attested by the highest specific $\mathrm{N}$ mineralisation rates and fastest turnover rate of $\mathrm{NH}_{4}{ }^{+}$pool in the agroforest sites. On the other hand, the maize sites showed the lowest $\mathrm{NH}_{4}{ }^{+}$cycling activity despite its high microbial biomass size. These results suggest that microbial biomass size alone was not a good indicator of the soil N-supplying capacity under these land use systems.

Furthermore, the difference in $\mathrm{NH}_{4}{ }^{+}$cycling activity in these land use systems could be due in part to the difference in quality and quantity of available organic matter. In the case of maize, continuous cultivation and $\mathrm{N}$ export by harvest without external $\mathrm{N}$ input must have depleted the organic $\mathrm{N}$ stock which could be potentially mineralized. The chronosequence study in the same research area showed declining soil $\mathrm{C}$ and $\mathrm{N}$ stocks under continuous maize cultivation, and a tendency to increase $\mathrm{C}$ and $\mathrm{N}$ stocks under agroforestry system (see chapter 2). In the case of agroforestry systems, leguminous shade trees which are able to biologically fix $\mathrm{N}_{2}$ could provide additional $\mathrm{N}$ to the system through their litterfall and prunings (Beer et al., 1998; Schroth et al., 2001). However, the scale of this process remains relatively unclear, and depends on management, tree species, and soil conditions (Beer et al., 1998). 


\subsection{Conclusions}

In the case of Central Sulawesi, which has ongoing conversion of rainforest to unfertilised agricultural systems, agroforestry is a better option compared to maize in terms of sustainability in N-supplying capacity of the soil. This study showed that $\mathrm{N}$ cycling rates under agroforestry system were comparable with the rates under natural forest, whereas the rates under maize cultivation were the lowest. These results suggest that legume shade trees are an important part of these agroforestry systems, which influence the soil $\mathrm{N}$ cycling by adding N-rich litter to the system. These results also showed that microbial biomass size did not reflect the rates of soil $\mathrm{N}$ cycling under these land use systems, and hence microbial biomass cannot be used as an indicator of the N-supplying capacity in these land use types. Moreover, the overall effect of agroforestry on soil fertility will need to be further evaluated on other nutrients, e.g. its effect on phosphorus. 


\section{Nutrient balances in maize and agroforestry compared to natural rainforest in Central Sulawesi, Indonesia}

\subsection{Introduction}

In many agricultural land use systems of rainforest margins (e.g. slash-and-burn systems) nutrient inputs by fertilisation are low, and nutrients exported through harvest from the system are often not replaced (Hölscher 1995, Sommer 2000). Furthermore, after clear cutting of natural forest, large amounts of nutrients from slashed biomass and from the soil are mineralised and not replaced by litter input (Bruijnzeel 1991, Mackensen 1998). In addition, the timing and rate at which nutrients are released and taken up may differ strongly, e.g. low uptake of nutrients by young crop plants. This, combined with high rainfall and reduced interception on converted sites, may result in nutrient losses through leaching (Bruijnzeel 1995, Klinge 1998). Regular burning of weed- or harvest-residues on agricultural sites also adds to losses of nutrients through volatilisation (Hölscher 1995, Sommer 2000). If management results in continuously negative nutrient balances, these land use systems are unsustainable and will degrade with time.

This has been shown by studies in tropical areas with acidic, deeply weathered soils, where forest conversion resulted in a fast decline of harvests (Nye and Greenland 1962, Finck 1963), and in slash-and-burn cropping systems with fallow periods, where large nutrient losses per cultivation cycle were found (Hölscher et al. 1997).

Contrary to agricultural land use systems, late successional vegetation types like natural tropical rain forests have reduced nutrient losses and are close to a steady state with inputs close or equal to outputs. The tight nutrient cycling between the ecosystem compartments (Brouwer 1996), stabilizes these vegetation forms over long periods of time. However, Vitousek and Sanford (1986) and Bruijnzeel (1991) differentiate between forests on poor and rich substrates, and cite evidence that under fertile soil conditions nutrient cycling is less conserving than under nutrient poor conditions.

This study was conducted in Central Sulawesi, Indonesia, where relatively young and fertile soils predominate (see chapter 2). Main land use systems on upland sites are unfertilised continuous maize cultivation without fallow periods, and unfertilised cocoa and coffee 
agroforestry. Without nutrient replacement by fertilization, agricultural cultivation will export nutrients from the sites and cause depletion of soil nutrient stocks. This was supported in a chronosequence study (chapter 2), where declining soil $\mathrm{N}$ and $\mathrm{C}$ stocks were found during maize cultivation, indicating net nutrient losses. However, in agroforestry systems soil $\mathrm{N}$ and C stocks were stable or even had the tendency to increase.

Overall goal in the present study was to detect whether agricultural land use systems on these soils have negative nutrient balances, and to evaluate if nutrient losses makes these agricultural systems unsustainable. Second goal was to find out which pathway is most important for nutrient loss of the major plant nutrients. A case study at two locations was conducted, in which nutrient inputs by precipitation and outputs by leaching and harvest export were measured. This was done for the dominant land use systems of the research area: maize and cocoa/coffee agroforestry, and natural forest as a reference. 


\subsection{Materials and methods}

\subsubsection{Sites selection and soil parameters}

Two locations were selected which had different land use systems close to each other on relatively homogenous soil to enable comparison of nutrient input and output fluxes under different agricultural management. Both locations were east of the Lore Lindu National Park, Sulawesi. Location 1 was south-east of the village Wuasa (WGS84, 51M0200280, UTM 9841920) on deep, alluvial sediments with sandy loam texture. Three land use systems were selected here: forest, agroforestry and maize; soil type was fluvic cambisol (FAO, 1998a). Location 2 was north-east of the village Wanga (WGS84, 51M0202153, UTM 9834837) on a slope on relatively deeply weathered phyllite as parent material and a clay texture. Two land use systems were selected here: forest and maize; soil type was dystric cambisol. Location 1 is identical with location 1 in chapter 3 , location 2 is identical with location 3 in chapter 3 , coordinates given here were measured with GPS handsets at the centers of the maize sites. Both locations were ca. $1100 \mathrm{~m}$ above sea level close to the north-eastern border of the Lore Lindu National Park in Central Sulawesi. Both maize fields had been cultivated continuously with maize for at least 2-3 years, the agroforestry site in Location 1 was established from natural forest 6 years before. In Location 1 in both managed systems coarse woody debris from the originally cleared forest could still be observed. The forest reference in both locations was disturbed by selective removal of individual trees of species with valuable wood, and by planting of some coffee shrubs in open spaces, but both sites still had a high density and coverage of large trees. In both locations areas with different land use systems were not further than $50 \mathrm{~m}$ apart. The size of the maize plot in location 1 was $50 \mathrm{~m} \times 75 \mathrm{~m}$, the agroforestry plot was $50 \mathrm{~m}$ x $80 \mathrm{~m}$, and the maize plot in location 2 was $50 \mathrm{~m} \times 50 \mathrm{~m}$.

Maize was planted on February 28, 2002 in location 1 and March 4 in location 2, and harvested on June 6 and June 1, respectively. Second replanting took place on July 27 and July 12, respectively. The second harvest in the year was October 30, and November 7, respectively. Planting density of maize was about 40,000-50,000 plants per hectare. The agroforestry site was a mixed stand of cocoa (40\%), coffee (60\%) and shade trees (Erythrina fusca and Gliricidia sepium). Cocoa and coffee was planted approximately at 2 x $2 \mathrm{~m}$ spacing (about 2000-3000 plants per hectare), and shade trees at about 5 x 5 m. Cocoa was often 
younger than coffee, inter-planted between larger coffee plants, so that the cocoa was at the center of the open space between 4 coffee plants.

For all sites, soil samples were taken from 0-10 and 30-40 cm depth and analysed for total C, $\mathrm{N}$, P, exchangeable cations ( $\mathrm{K}, \mathrm{Ca}, \mathrm{Mg}, \mathrm{Na}$ ), $\mathrm{pH}$, bulk density, texture and ECEC (for methods of soil sample analysis see chapter 2.2.2). Soil nutrient stocks $0-40 \mathrm{~cm}$ depth were calculated by using data from samples of $0-10 \mathrm{~cm}$ depth for $0-20 \mathrm{~cm}$ depth and data from samples of 30-40 cm depth for 20-40 cm depth.

All selected agricultural sites had been established by local farmers, and management during the measurements continued according to the local farmers' management practice. Farmers did not apply fertiliser or manure on the research sites. Forest sites were studied as reference representing the undisturbed situation.

\subsubsection{Instrumentation}

On all sites of location 1 and the maize site of location 2 a total of 16 lysimeters (plastic pipes with ceramic suction cups at the end) were installed in $1.20 \mathrm{~m}$ depth to collect soil-water samples. In location 2 on the forest site 8 lysimeters were installed. It was assumed that soil water samples from this depth were taken below the main rooting zone. Suction cups had been washed with acid and destilled water before use to remove possible traces of nutrients, especially N. Four lysimeters were placed at the corners of a square of approximately $1 \mathrm{~m}^{2}$; two lysimeters each were connected to one brown 0.5L glass bottle to collect the soil water, so that 8 bottles per site were collecting soil water samples. Glass bottles were placed in plastic buckets with lids, which were dug into the soil to protect them and allow work to continue on the managed sites. From the two bottles of one set of four lysimeters one composite soil water sample was taken weekly, four samples per site. In the forest site of location 2 only two sets of four lysimeters were installed. On each glass bottle a vacuum of 200-300 kPa was applied with a portable vacuum pump. Soil water samples were collected in PE-bottles of $100 \mathrm{~mL}, 14-20$ hours after application of the vacuum.

At both locations a set of 5 rain water samplers were installed on open areas $2 \mathrm{~m}$ above ground level. The rain water samplers were funnels of $10 \mathrm{~cm}$ diameter with a $0.5 \mathrm{~mm}$ plastic netting to prevent insects or leaves from entering, fixed to a $1 \mathrm{l}$ PE-bottle with a rubber cork which had an opening in the middle. Bottles were covered with reflective silver tape to avoid 
heating up of the rain water sample in the sun and development of algae. At each location, one composite sample of rain water was collected weekly. Soil and rain water samples were taken to the laboratory and were stored frozen within 24 hours after collection. Analysis of the soil water and rain water samples was conducted at the laboratory unit at Tadulako University, Palu. Samples were analysed for $\mathrm{pH}$, total N, P, K, Mg, Na, Al, and Ca, using ICP-OEC. Both $\mathrm{Al}$ and $\mathrm{P}$ were analysed only in the first batch of about 100 samples, but because all of these samples had values under detection limit these elements were not analysed further in the following samples.

\subsubsection{Water balance and leaching}

A simple water balance was calculated with climatic data obtained from climatic stations closest to the experimental site to estimate leaching from the soil profile. For location 1 (Wuasa) the distance to the climatic station was approx. 2-3 km, and for location 2 (Wanga) only ca. $60 \mathrm{~m}$. The data set of the climatic stations included mean daily temperature, humidity and wind speed. Potential evapotranspiration was calculated with the Penman-Monteith formula on a daily basis following procedures given by FAO (1998b). FAO's standard calibration values were used for a reference crop (watered grass, $12 \mathrm{~cm}$ height) which is recommended by FAO (1998b) as it has shown to be representative of a wide range of climatic and vegetational situations and enables comparisons with other studies (albedo 0.23, aerodynamic resistance 200, canopy resistance 70).

From daily means weekly sums were calculated of both precipitation and evapotranspiration. Weekly evapotranspiration was subtracted from the weekly rainfall and excess rainfall was assumed to percolate the soil and leave the system. Crop factors were not included to reduce potential evapotranspiration in maize or agroforestry, because for warm and humid conditions with low wind speed potential evapotranspiration is assumed to be close or equal to actual evapotranspiration (FAO, 1998b).

Soil water and rain water was collected weekly from March- October 2002 and analysed for nutrient concentrations (total $\mathrm{N}, \mathrm{pH}, \mathrm{Ca}, \mathrm{K}, \mathrm{Mg}$, and $\mathrm{Na}$ ). Leaching of nutrients per area was calculated from data of nutrient concentration in soil water and the amount of water leaching per week. For months without concentration data mean concentration data were used from the period which was sampled. Nutrient fluxes were calculated as $\mathrm{kg} \mathrm{ha}^{-1} \mathrm{a}^{-1}$. 
The leaching calculation is considered to be a conservative estimate for agricultural sites, because other studies report conversion of forest into agricultural land to result in increase in water yield of around $200 \mathrm{~mm} \mathrm{a}^{-1}$ compared to natural forest (Bruijnzeel 1990), due to reduced interception and transpiration. Additional water flow of this scale in this study would increase leaching losses of nutrients by about $20 \%$. Therefore calculated leaching losses must be regarded cautiously in absence of reliable data for actual ET for each land use system separately. It also must be noted that nutrient balances in mixed agroforestry sites may vary depending on proportions of coffee, cocoa, and shade trees, and also planting densities. These parameters varied across the research region.

\subsubsection{Harvest}

On the maize and agroforestry sites nutrient export through harvest was measured. Maize was harvested by taking only the maize cob without the sheath of leaves, following the general practice of farmers in the area. The maize-plant residuals were left on the field to rot or burned in small heaps scattered across the field. Maize harvest were estimated by harvesting 5 replicates of $4 \mathrm{~m}^{2}$ subplots, drying of the maize-cobs for 24 hours at $105^{\circ} \mathrm{C}$ and calculating the total harvest of maize cobs dry matter per site. The harvest was analysed for concentrations of macronutrients $\mathrm{N}, \mathrm{C}, \mathrm{Mg}, \mathrm{Ca}, \mathrm{K}$ and $\mathrm{Na}$. Planting frequency in the research area varied, but according to observations maize cultivation was done continuously without distinct fallow periods or planting seasons, and many growth stages were present at one time. Time between sowing and harvesting of maize was approximately 4.5 months. Including a short period of 1-2 months where weeds are controlled and harvest is processed, an average of 2 harvests of maize per year was estimated conservatively. Export of nutrients per area and year were calculated from harvest data, number of harvests per year and nutrient concentrations in maize harvest.

On agroforestry sites harvesting was a continuing process with harvests of coffee or cocoa weekly or bi-weekly. Samples of the coffee- or cocoa fruits were taken reglarily and analysed for nutrient concentrations. Total export was estimated by interviewing the farmer every week about the harvest (in kg) of the week before. Farmers export the ripe coffee-berries from the site, while the cocoa fruits are opened and only the beans are exported from the site. Most agroforestry sites are mixed stands with a high variety of fruits, nuts vegetables or other 
cultivated plants. On the research site these other crops, especially vegetables (cassava, sweet potato, banana, chili, pineapple, cucumber and pumpkin), were of negligible amounts and were not included into this study. Apart from coffee and cocoa one other crop was included: Candle Nut (indonesian: Kemiri), Aleurites mollucana, of which about $1 \mathrm{Mg} \mathrm{ha}^{-1} \mathrm{a}^{-1}$ was harvested. This fast-growing tree yields fruits that contain nuts, the fatty kernels of these nuts are mostly sold and used to produce oil. Fruits are collected after they drop from the tree, they are opened and only the dried nuts are removed from the site. Candle Nut trees are sometimes 7planted within the agroforestry system, replacing some of the shade trees, but more often they occur along the border of the field.

\subsection{Results}

\subsubsection{Water balance}

The wet season was between May and June, and the dry season from July until October (Figure 10 and 11). In three months (March-May) $46 \%$ of annual precipitation was measured. Evapotranspiration was $65 \%$ of annual precipitation. Temperature, humidity and wind speed did not vary much during the year (Table 13), daily average amplitude of maximum and minimum temperature was about $8{ }^{\circ} \mathrm{C}$. Water balance calculations (P-ET) showed highest perkolation of water from March until end of May. During this time about $85 \%$ of the annual amount of leaching was calculated. During July and August calculations of weekly water balance resulted often in evapotranspiration exceeding precipitation (Figure 10 and 11).

Table 13. Climatic data and water balance, December 01-December 02 , $(\mathrm{T}=$ temperature, $\mathrm{P}=$ precipitation, ET= Evapotranspiration, $\mathrm{R}$ = global radiation), annual sums (P, ET, P-ET) and annual means of daily means (P, ET, rel. hum., windspeed, R, cloudiness).

\begin{tabular}{lcccccccccc}
\hline & $\begin{array}{c}\mathrm{T} \\
{ }^{\circ} \mathrm{C}\end{array}$ & $\begin{array}{c}\text { rel. hum } \\
\%\end{array}$ & $\begin{array}{c}\mathrm{P} \\
\mathrm{mm} \mathrm{d}^{-1}\end{array}$ & $\begin{array}{c}\mathrm{P} \\
\mathrm{mm} \mathrm{a}^{-1}\end{array}$ & $\begin{array}{c}\mathrm{ET} \\
\mathrm{mm} \mathrm{d}^{-1}\end{array}$ & $\begin{array}{c}\mathrm{ET} \\
\mathrm{mm} \mathrm{a}^{-1}\end{array}$ & $\begin{array}{c}\text { wind } \\
\mathrm{m} \mathrm{s}^{-1}\end{array}$ & $\begin{array}{c}\mathrm{R} \\
\mathrm{Mj} \mathrm{m}^{2} \mathrm{~d}^{-1}\end{array}$ & $\begin{array}{c}\mathrm{P}-\mathrm{ET} \\
\mathrm{mm} \mathrm{a}^{-1}\end{array}$ & $\begin{array}{c}\text { cloud. } \\
\%\end{array}$ \\
\hline Loc. 1 & 21.1 & 81.4 & 4.2 & 1525 & 2.7 & 985 & 1.0 & 18.3 & 540 & 62 \\
Loc. 2 & 21.4 & 80.2 & 3.9 & 1427 & 2.7 & 1002 & 1.0 & 18.2 & 425 & 62 \\
\hline
\end{tabular}




\subsubsection{Nutrient input by rain and output by leaching}

Input by rain differed between both locations. In location 2, inputs by rain were lower for N, $\mathrm{Ca}, \mathrm{K}$ and $\mathrm{Na}$ because of lower concentrations and lower annual precipitation, only Mg input was slightly higher in location 2 compared to location $1, \mathrm{~N}$ and $\mathrm{K}$ inputs were about $50 \%$ lower in location 2 compared to location 1, mainly due to different concentrations in rain water (Table 17, Figure 12). In both agricultural systems N, Ca and Mg inputs by rain were insignificant compared to leaching and harvest exports. However, precipitation replaced 54\% of $\mathrm{K}$ in maize of location 1 and $32 \%$ of $\mathrm{K}$ in maize of location 2, and $19 \%$ of $\mathrm{K}$ losses in agroforestry. In natural forest, rain replaced 32 and $70 \%$ of $\mathrm{N}$ leaching losses, respectively. In the forest of location $2, \mathrm{~K}$ input by rain exceeded outputs, resulting in positive $\mathrm{K}$ balance (Table 17).

In general, leaching losses on less fertile soils on weathered phyllite (location 2) were considerably lower than on more fertile alluvial soils (location 1). Leaching losses of $\mathrm{N}$ in forest were four times higher in location 1 than in location 2, leaching losses of $\mathrm{Ca}$ and $\mathrm{K}$ were even six times higher in location 1 compared to location 2 (Table 17, Figures 15 and 16). This was mainly due to lower nutrient concentrations in soil water of location 2 (Figures 12-14). It seems that differences in leaching losses depended more on soil type than on land use type. Nitrogen was the only notable exception.

Concentrations of $\mathrm{Al}$ and $\mathrm{P}$ in soil and rain water were below detection limit; therefore $\mathrm{P}$ balances in natural forest without harvest export were calculated as zero. In agroforestry, leaching losses were highest for $\mathrm{N}$, Ca and Mg compared to forest and maize.

\subsubsection{Harvest exports and input output balances of nutrients}

Maize yields were about $2 \mathrm{Mg} \mathrm{ha}^{-1}$ per harvest and 4.0 and 4.2 $\mathrm{Mg} \mathrm{ha}^{-1}$ per year (Table 16). Although the dry weight biomass export was substantially higher in maize culture than in the agroforestry system, fresh weight biomass export was similar in both systems. This was caused by the low dry matter content of coffee beans, which was the major crop in the mixed agroforestry system in this case study.

Harvest export of nutrients was higher in the agroforestry system for all elements compared to maize (Table 17, Figure 15). Especially N, K, Mg and Ca exports are substantially higher in 
the agroforestry system. K-export was cause by the high potassium content of coffee beans, Ca-export was mainly caused by the shells of the Candle nuts and with the coffee-harvest (see Appendix, Table 26). Although dry weight of the maize harvest is similar in both locations, harvest export of $\mathrm{P}, \mathrm{K}$ and $\mathrm{Mg}$ differed between the two locations, because the concentration of $\mathrm{P}, \mathrm{K}$ and $\mathrm{Mg}$ in maize seeds was substantially higher in location 2 compared to location 1. Nutrient losses under forest were lower than maize and agroforestry except for Ca and $\mathrm{Na}$. In location 1 forest had highest Na losses of all three land use systems. In both agroforestry and maize, leaching was the major output pathway for $\mathrm{Ca}$, $\mathrm{Na}$ and $\mathrm{Mg}$ (> $50 \%$ of total losses). The main output pathway for N, P and K was harvest (Table 18, Figures 15 and 16).

Annual net losses of total $\mathrm{N}$, total $\mathrm{P}$ and exchangeable $\mathrm{Ca}$ in all agricultural systems were below $1 \%$ of total soil stocks of each element in 0-40 cm depth. In agroforestry of location 1 , $\mathrm{K}$ and $\mathrm{Mg}$ losses were $14.3 \%$ and $4.5 \%$ of exchangeable stocks, respectively. $\mathrm{K}$ losses in maize of location 2 were $7.8 \%$ of exchangeable stocks (Table 19).

Table 14. Soil texture (0-10 cm depth), $C, N$ and $P$ stocks $(0-40 \mathrm{~cm}$ depth) and soil chemical parameters $(0-10 \mathrm{~cm}$ depth) of the research sites $(\mathrm{NF}=$ natural forest, $\mathrm{AF}=$ agroforestry, $\mathrm{MF}$ $=$ maize field)

\begin{tabular}{|c|c|c|c|c|c|c|c|c|c|}
\hline \multirow[t]{2}{*}{ Site } & Clay & Sand & Silt & $\mathrm{C}$ & $\mathrm{N}$ & $\mathrm{P}$ & $\mathrm{BS}$ & ECEC & $\mathrm{pH}$ \\
\hline & & $\%$ & \multicolumn{4}{|c|}{$\mathrm{Mg} \mathrm{ha}^{-1}, 0-40 \mathrm{~cm}$} & $\%$ & $\mathrm{mmol} \mathrm{kg}{ }^{-1}$ & $\mathrm{KCl}$ \\
\hline & \multicolumn{9}{|c|}{ Location 1, fluvic cambisol } \\
\hline NF & 22.8 & 51.3 & 25.9 & 109.0 & 10.6 & 2.9 & 98.9 & 220 & 5.8 \\
\hline $\mathrm{AF}$ & 18.0 & 58.1 & 24.0 & 97.4 & 9.9 & 2.6 & 99.4 & 181 & 5.7 \\
\hline \multirow[t]{2}{*}{ MF } & 15.2 & 45.2 & 39.6 & 134.6 & 11.8 & 2.7 & 99.6 & 332 & 6.5 \\
\hline & \multicolumn{9}{|c|}{ Location 2, dystric cambisol } \\
\hline NF & 59.6 & 13.6 & 26.8 & 134.8 & 9.3 & 2.1 & 76.7 & 96 & 4.4 \\
\hline MF & 63.0 & 8.5 & 28.3 & 134.4 & 11.0 & 4.6 & 85.9 & 122 & 4.6 \\
\hline
\end{tabular}


Table 15. Exchangeable base cation stocks (0-40 cm depth), and percentage of exchangeable cations of total base cation stocks

\begin{tabular}{lcccccc}
\hline & Ca & $\begin{array}{c}\mathrm{K} \\
\mathrm{Mg} \mathrm{ha}^{-1}\end{array}$ & $\mathrm{Mg}$ & $\mathrm{Ca}$ & $\begin{array}{c}\mathrm{K} \\
\text { \% of total stock }\end{array}$ & $\mathrm{Mg}$ \\
\multicolumn{7}{c}{ Location 1, fluvic cambisol } \\
NF 1 & 23.4 & 0.5 & 1.6 & 81.0 & 1.3 & 3.1 \\
AF 1 & 20.1 & 0.5 & 1.4 & 75.2 & 1.5 & 2.9 \\
MF 1 & 35.2 & 1.0 & 5.1 & 81.0 & 2.7 & 5.0 \\
& & & Location 2, dystric cambisol & & \\
NF 2 & 5.6 & 0.3 & 1.5 & 31.2 & 44.5 & 12.0 \\
MF 2 & 7.6 & 0.2 & 1.6 & 47.5 & 55.6 & 13.8 \\
\hline
\end{tabular}

Table 16. Removal of biomass by harvest, fresh weight (FW) and dry weight DW, kg ha ${ }^{-1}$

\begin{tabular}{lcrr}
\hline & & per harvest $\left(\mathrm{kg} \mathrm{ha}^{-1}\right)$ & per year $\left(\mathrm{kg} \mathrm{ha}^{-1}\right)$ \\
Location & & DW & DW \\
\hline 1 & Maize, total $^{1}$ & $\mathbf{2 0 1 0}$ & $\mathbf{4 0 2 0}$ \\
1 & Maize seeds $^{1}$ & 1660 & 3320 \\
1 & Maize stalks $^{1}$ & 350 & 700 \\
2 & Maize, total & $\mathbf{2 1 3 0}$ & $\mathbf{4 2 6 0}$ \\
2 & Maize seeds $^{1}$ & 1720 & 3440 \\
2 & Maize stalks $^{1}$ & 410 & 820 \\
1 & Agroforestry, total: $^{2}$ & $\mathbf{2 6 8 0}$ \\
1 & Coffee $^{2}$ & 1140 \\
1 & Cocoa $^{2}$ & 540 \\
1 & Candle Nut $^{2}$ & 900 \\
1 & Shells $^{2}$ & 405 \\
1 & Kernels $^{2}$ & 495 \\
\hline 1 & ${ }_{2}$ measured $^{2}$ information provided by farmer $^{2}$ &
\end{tabular}


Table 17. Annual input-output balance of nutrients ( $\mathrm{kg} \mathrm{ha}^{-1}$ )

\begin{tabular}{|c|c|c|c|c|c|c|}
\hline & $\mathrm{N}$ & $P$ & $\mathrm{Ca}$ & $\mathrm{K}$ & $\mathrm{Mg}$ & $\mathrm{Na}$ \\
\hline \multicolumn{7}{|c|}{ Forest 1} \\
\hline In: Rain & 2.7 & n. d. & 7.6 & 20.6 & 0.2 & 7.2 \\
\hline Out: Leaching & 8.5 & n. d. & 62.7 & 36.3 & 12.6 & 27.9 \\
\hline Balance & -5.8 & $\mathbf{0}$ & -55.1 & -15.7 & -12.4 & -20.7 \\
\hline \multicolumn{7}{|c|}{ Forest 2} \\
\hline In: Rain & 1.4 & n. d. & 4.4 & 10.1 & 0.7 & 6.2 \\
\hline Out: Leaching & 2 & n. d. & 10.6 & 5.1 & 5.5 & 8.2 \\
\hline Balance & -0.6 & $\mathbf{0}$ & -6.2 & 5.0 & -4.8 & -2 \\
\hline \multicolumn{7}{|c|}{ Agroforest 1} \\
\hline In: Rain & 2.7 & 0 & 7.6 & 20.6 & 0.2 & 7.2 \\
\hline Out: Leaching & 19.6 & 0 & 133.6 & 34.8 & 23.5 & 13.1 \\
\hline Out: Harvest & 57.0 & 9.1 & 12.2 & 41.8 & 6.4 & 0 \\
\hline Balance & -73.9 & -9.1 & -138.2 & -56.0 & -29.7 & -5.9 \\
\hline \multicolumn{7}{|c|}{ Maize 1} \\
\hline In: Rain & 2.7 & n. d. & 7.6 & 20.6 & 0.2 & 7.2 \\
\hline Out: Leaching & 19.3 & n. d. & 51 & 19.3 & 12.2 & 17.6 \\
\hline Out: Harvest & 38.0 & 5.9 & 0.4 & 13.8 & 2.2 & 0 \\
\hline Balance & -54.6 & -5.9 & -43.8 & -12.5 & -14.2 & -10.4 \\
\hline \multicolumn{7}{|c|}{ Maize 2} \\
\hline In: Rain & 1.4 & n. d. & 4.4 & 10.1 & 0.7 & 6.2 \\
\hline Out: Leaching & 4.8 & n. d. & 7.9 & 4.6 & 2.4 & 8.9 \\
\hline Out: Harvest & 44.0 & 12.7 & 0.5 & 19.7 & 4.1 & 0 \\
\hline Balance & -47.4 & -12.7 & -4.0 & -14.2 & -5.8 & -2.7 \\
\hline
\end{tabular}


Table 18. Nutrient in- and outputs calculated as percentage of total outputs

\begin{tabular}{lrrrrrr}
\hline & $\mathbf{N}$ & $\mathbf{P}$ & $\mathbf{C a}$ & $\mathbf{K}$ & $\mathbf{M g}$ & $\mathbf{N a}$ \\
\hline & & & Forest 1 & & & \\
In: Rain & 31.8 & 0 & 12.1 & 56.7 & 1.6 & 25.8 \\
Out : Leaching & 100.0 & 0 & 100.0 & 100.0 & 100.0 & 100.0 \\
& & & Forest 2 & & & \\
In: Rain & 70.0 & 0 & 41.5 & 198.0 & 12.7 & 75.6 \\
Out : Leaching & 100.0 & 0 & 100.0 & 100.0 & 100.0 & 100.0 \\
& & & Agroforest & & & \\
In: Rain & 2.8 & 0 & 5.2 & 21.8 & 0.6 & 55.0 \\
Out : Leaching & 20.3 & 0 & 90.6 & 36.8 & 74.1 & 100.0 \\
Out: Harvest & 79.7 & 100.0 & 9.4 & 63.2 & 25.9 & 0.0 \\
& & & Maize 1 & & & \\
In: Rain & 4.7 & 0.0 & 14.8 & 62.2 & 1.4 & 40.9 \\
Out : Leaching & 33.7 & 0.0 & 99.2 & 58.3 & 84.7 & 100.0 \\
Out: Harvest & 66.3 & 100.0 & 0.8 & 41.7 & 15.3 & 0.0 \\
& & & Maize 2 & & & \\
In: Rain & 2.9 & 0.0 & 52.4 & 41.6 & 10.8 & 69.7 \\
Out : Leaching & 9.8 & 0.0 & 94.0 & 18.9 & 36.9 & 100.0 \\
Out: Harvest & 90.2 & 100.0 & 6.0 & 81.1 & 63.1 & 0.0
\end{tabular}

Table 19. Annual losses (-) or gains (+) of nutrients (percentage of soil stocks of total N, total $\mathrm{P}$, total Ca, $\mathrm{K}$ and $\mathrm{Mg}$, and exchangeable Ca, $\mathrm{K}$ and $\mathrm{Mg}, 0-40 \mathrm{~cm}$ depth)

\begin{tabular}{rrrrrrrrr}
\hline \multicolumn{1}{l}{ Site } & \multicolumn{4}{c}{ \% of total stocks } & \multicolumn{4}{c}{ \% of exchangeable stocks } \\
& $\mathrm{N}$ & $\mathrm{P}$ & $\mathrm{Ca}$ & $\mathrm{K}$ & $\mathrm{Mg}$ & $\mathrm{Ca}$ & $\mathrm{K}$ & $\mathrm{Mg}$ \\
\hline NF 1 & -0.1 & -0.0 & -0.4 & -0.04 & -0.1 & 0.5 & -2.9 & 1.6 \\
AF 1 & -1.0 & -0.5 & -1.1 & -0.2 & -0.1 & 0.3 & -14.3 & 4.5 \\
MF 1 & -0.5 & -0.2 & -0.2 & -0.04 & -0.1 & 1.4 & -1.3 & 1.3 \\
NF 2 & -0.01 & -0.0 & -0.1 & $+\mathbf{0 . 9}$ & -0.1 & 0.2 & $+\mathbf{2 . 0}$ & 0.6 \\
MF 2 & -0.4 & -0.3 & -0.1 & -4.3 & -0.1 & 0.1 & -7.8 & 0.7 \\
\hline
\end{tabular}



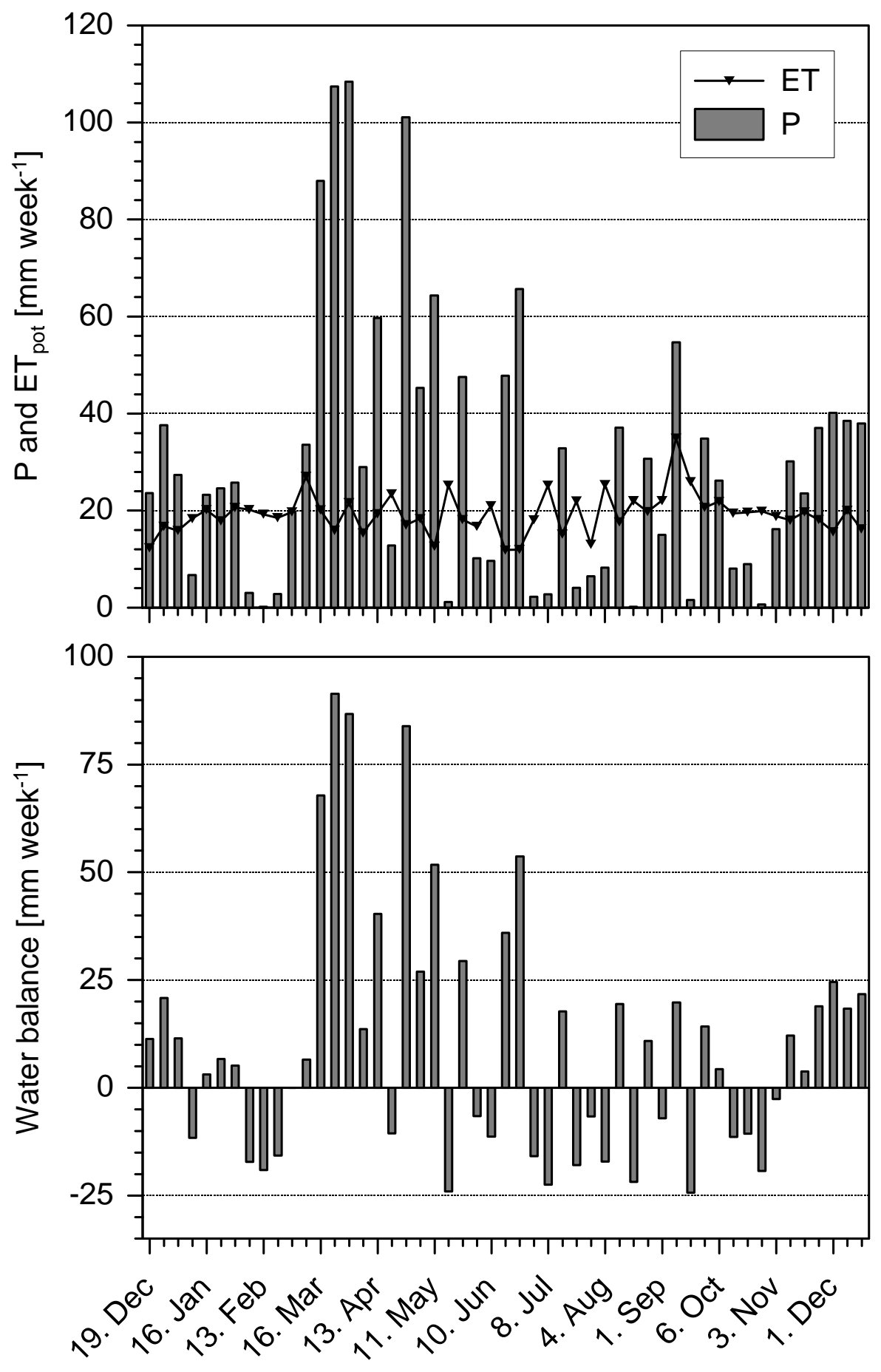

Figure 12. Precipitation, evapotranspiration and water balance in location 1 for 2002, (mm per week) 

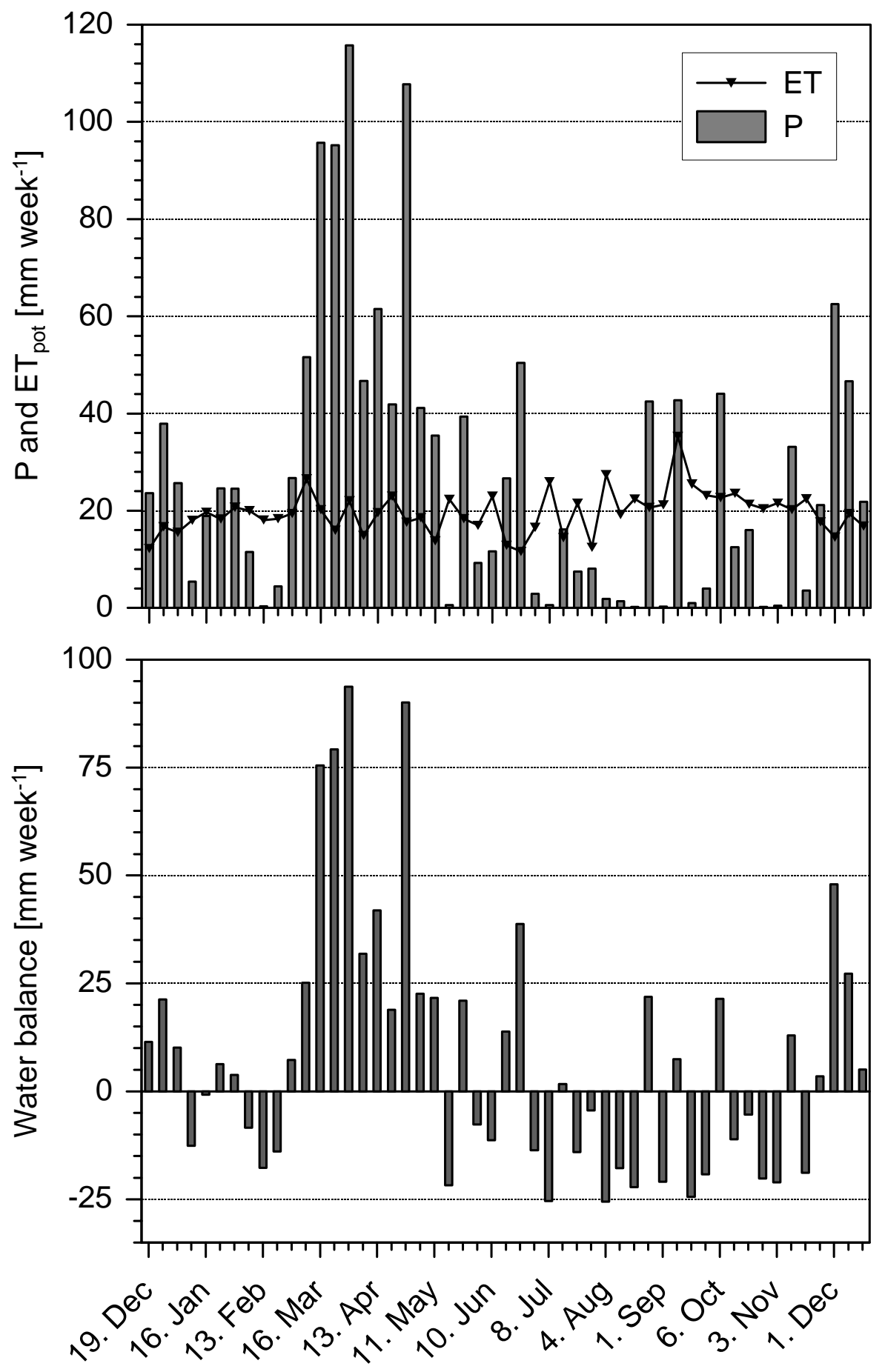

Figure 13. Precipitation, evapotranspiration and water balance in location 2 for 2002, (mm per week) 

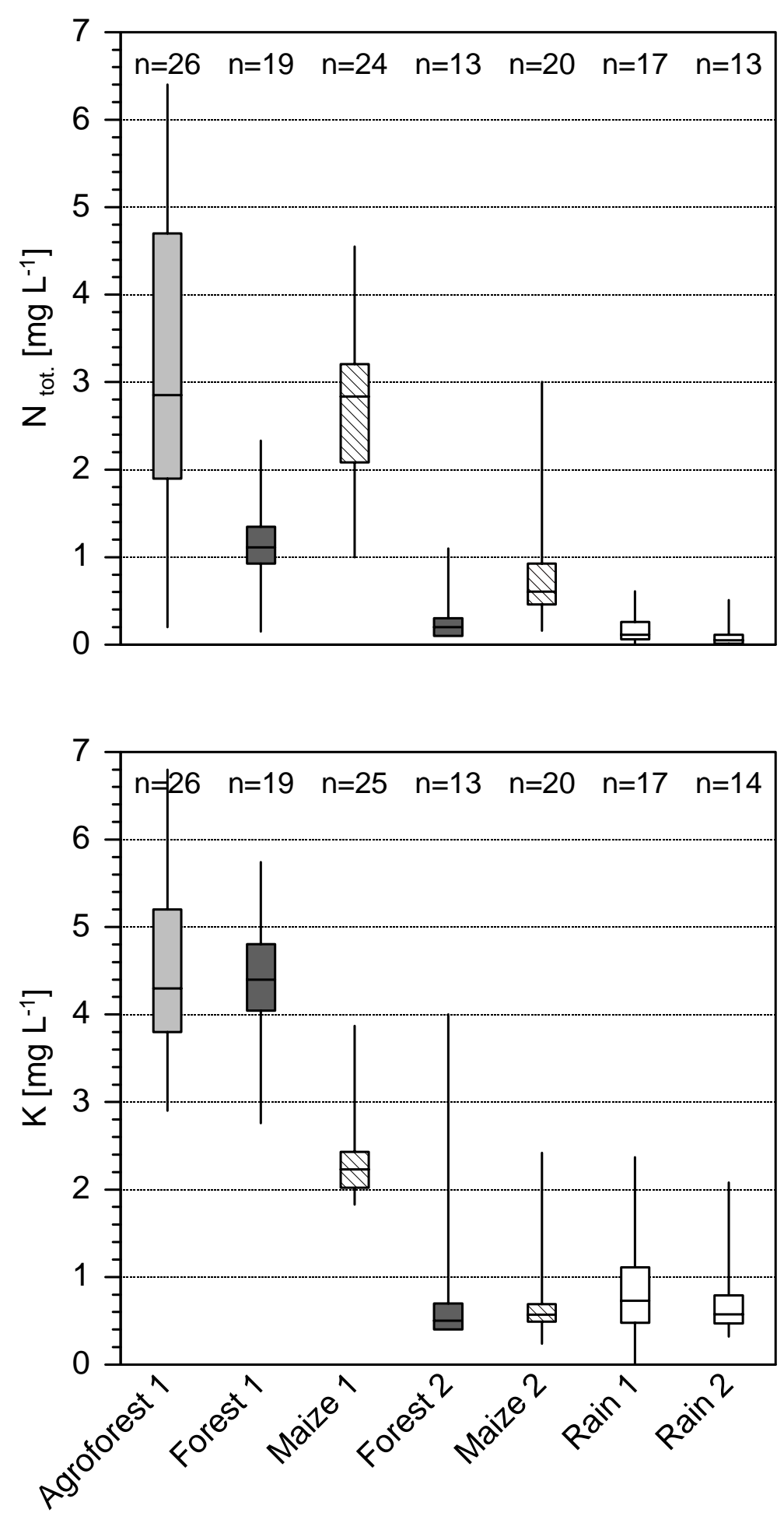

Figure 14. Rain and soil water concentrations of $\mathrm{N}$ and $\mathrm{K}$ for each site (median, 25 and 75 percentil, maxima and minima) 

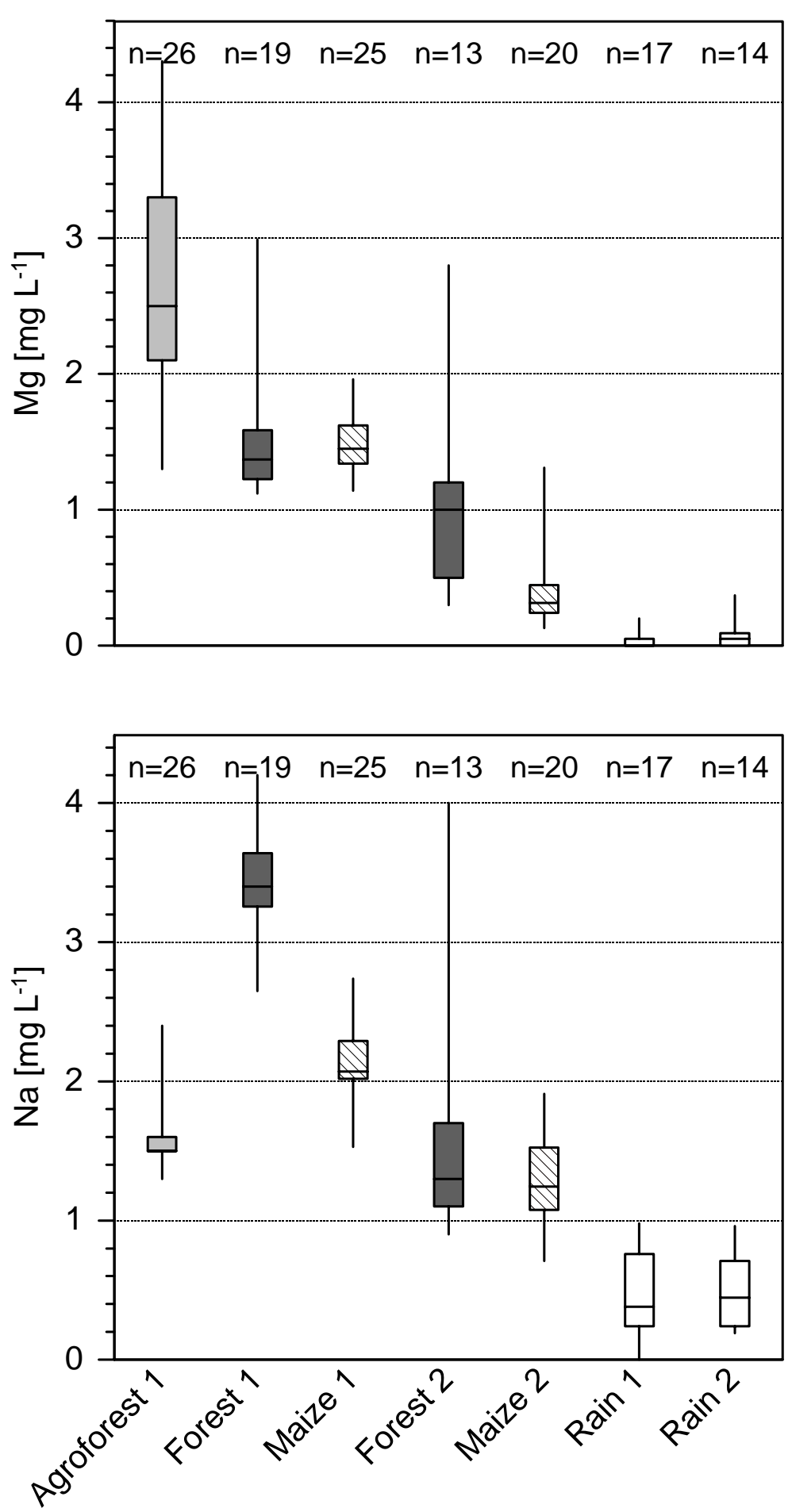

Figure 15. Rain and soil water concentrations of $\mathrm{Mg}$ and $\mathrm{Na}$ for each site (median, 25 and 75 percentil, maxima and minima) 

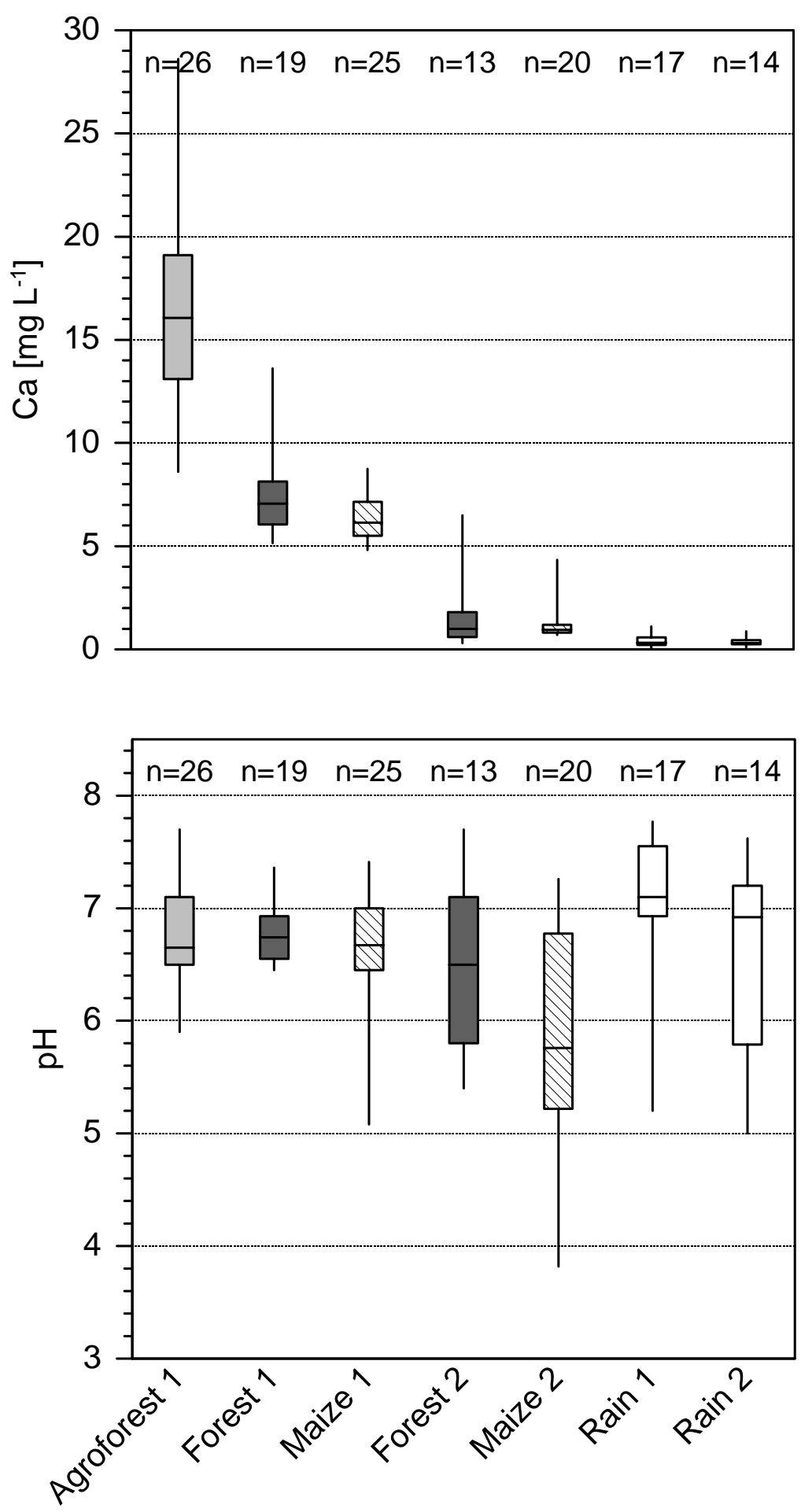

Figure 16. Rain and soil water concentrations of $\mathrm{Ca}$ and $\mathrm{pH}$ for each site (median, 25 and 75 percentil, maxima and minima) 

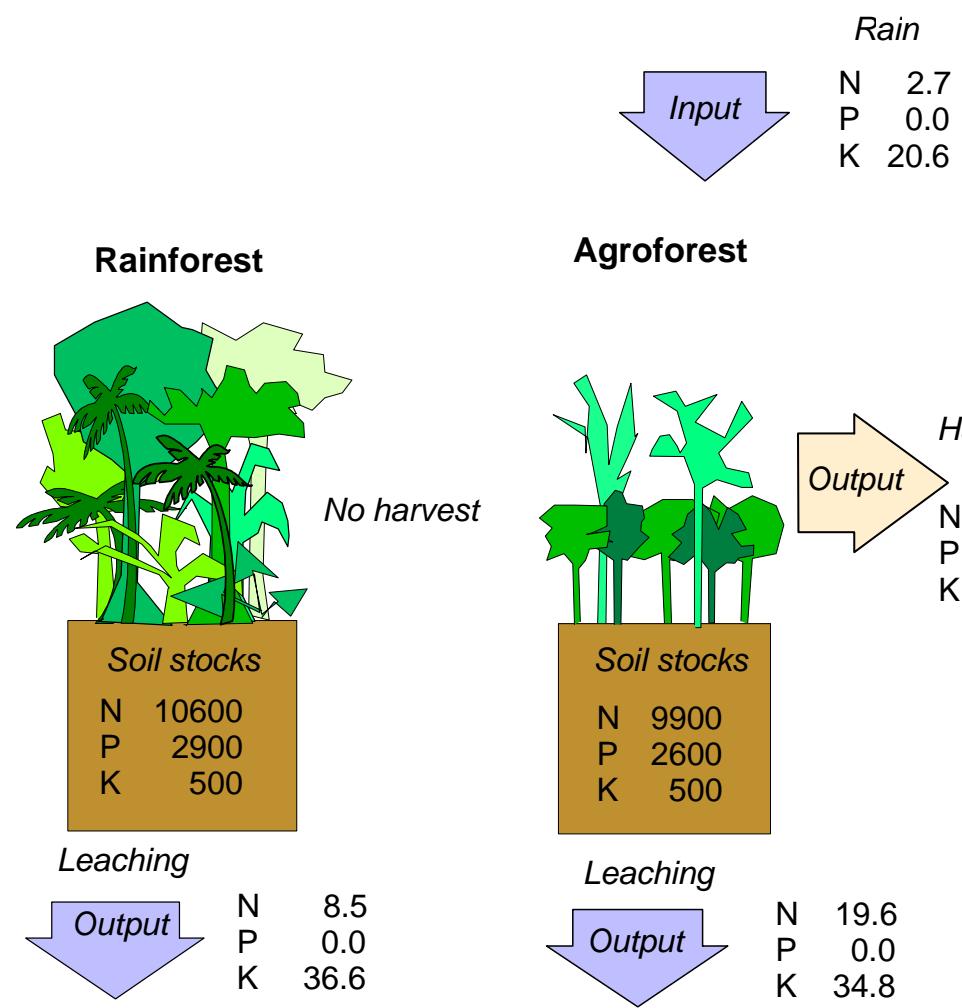

Agroforest

Maize
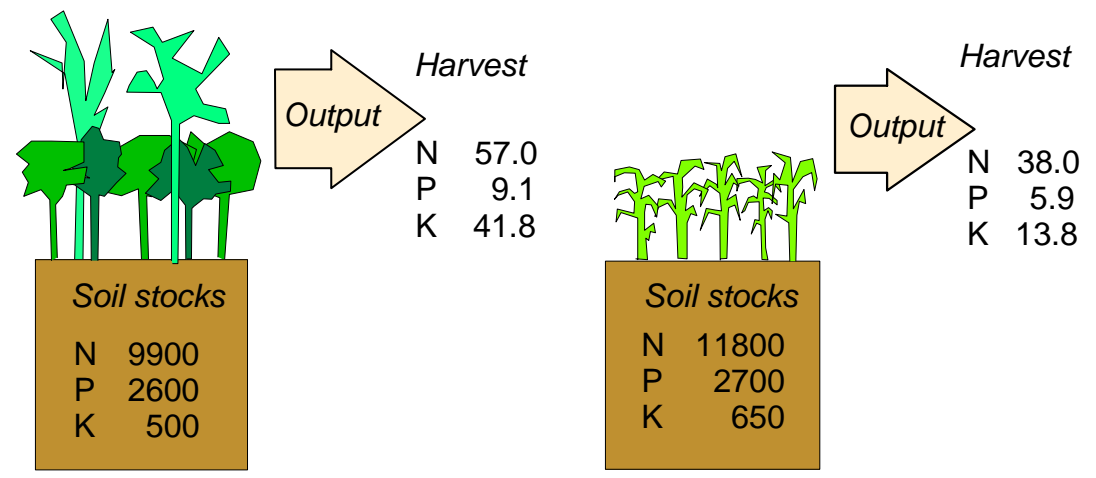

Leaching

$\begin{array}{rrr}\text { Output } & \mathrm{N} & 19.6 \\ \mathrm{P} & 0.0 \\ \mathrm{~K} & 34.8\end{array}$

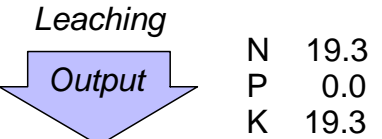

$\begin{array}{llr}\text { Balance: } & N & -5.8 \\ & P & 0.0 \\ & K & -15.7\end{array}$

Balance: $\begin{array}{rr}N & -73.9 \\ P & -9.1 \\ K & -56.0\end{array}$

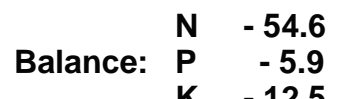

Figure 17. Nutrient balances in three land use systems in location 1, inputs and output values in $\mathrm{kg} \mathrm{ha}^{-1} \mathrm{a}^{-1}$, and soil nutrient stocks for soil depth 0-40 cm, kg ha-1. 

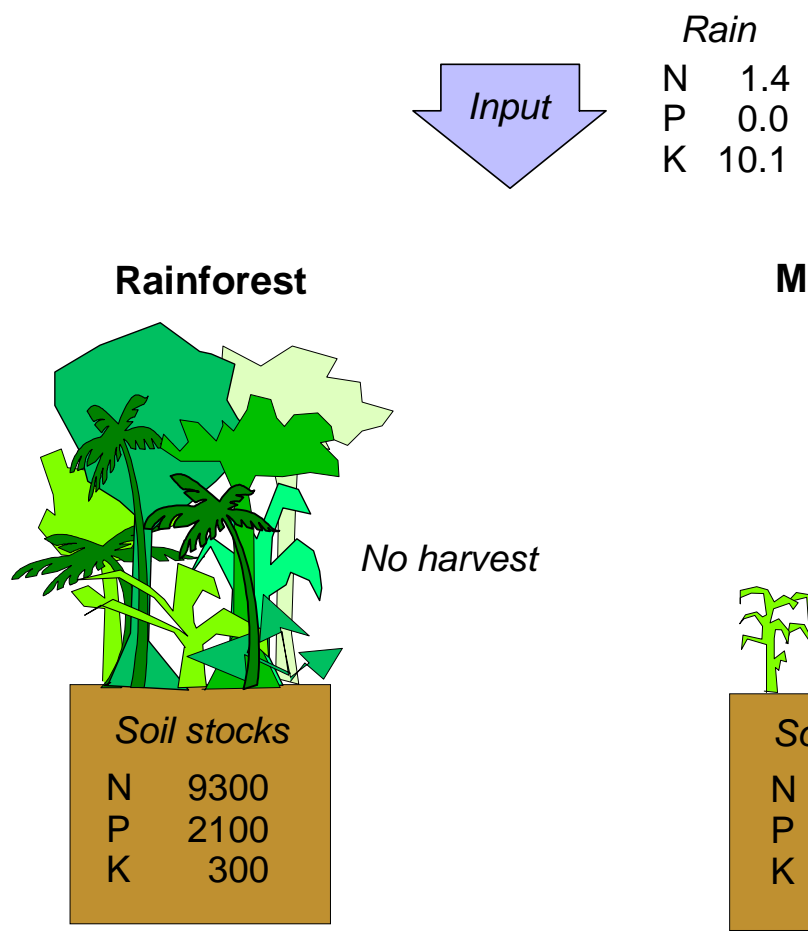

\section{Maize}
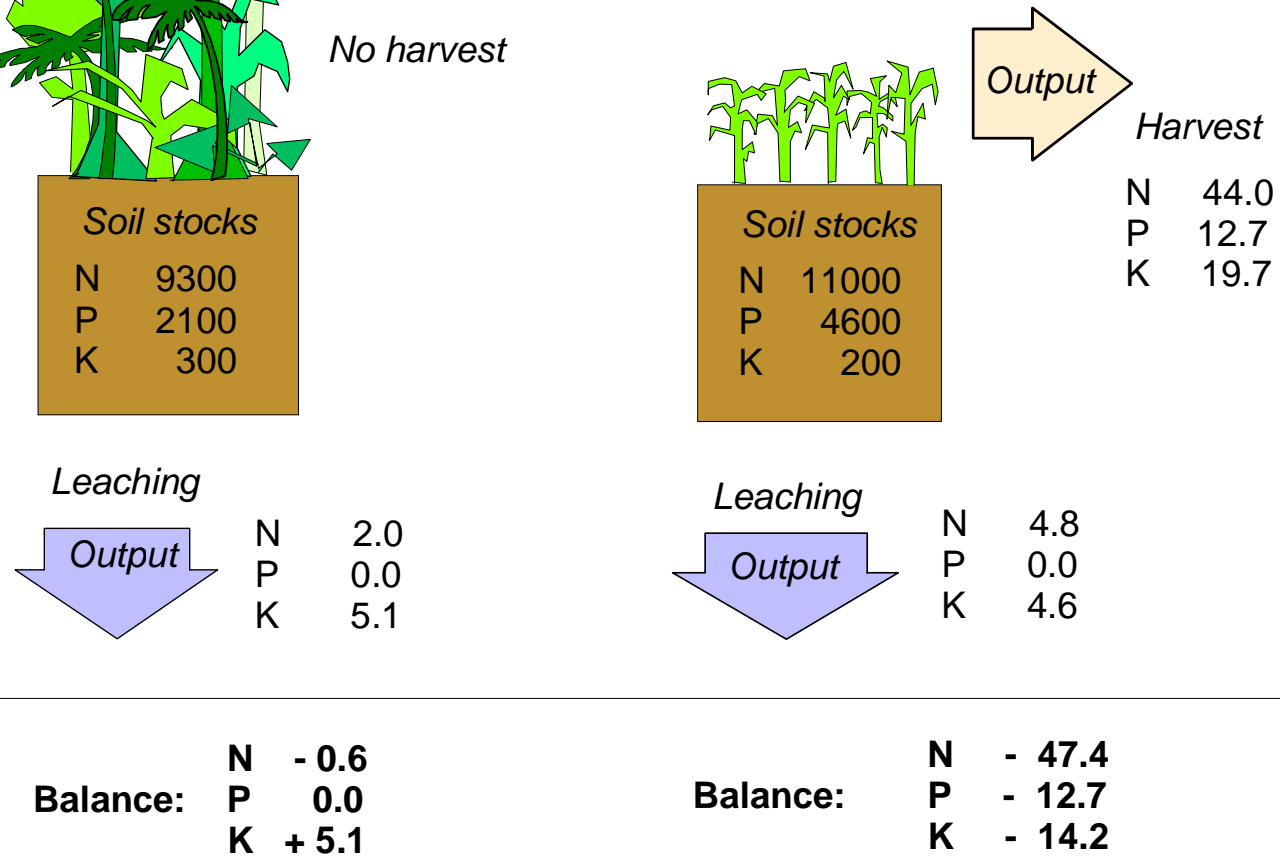

$\begin{array}{lll} & \text { N } & -47.4 \\ \text { Balance: } & \text { P } & -12.7 \\ & \text { K } & -14.2\end{array}$

Figure 18. Nutrient balances in two land use systems in location 2, inputs and output values in $\mathrm{kg} \mathrm{ha}^{-1} \mathrm{a}^{-1}$, and soil nutrient stocks for soil depth 0-40 cm, kg ha ${ }^{-1}$. 


\subsection{Discussion}

\subsubsection{Nutrient balances as indicators of sustainable land use}

In this case study nutrient balances in maize and agroforestry were negative for all major nutrients (Table 17). The annual nutrient losses were much higher than the ones reported for shifting cultivation systems on acid weathered soils. Annual nutrient losses were between 25 and $100 \%$ of nutrient exports during complete rotation cycles (of 7 to 9 years) in shifting cultivation systems in Eastern Amazonia, which included fallow periods and regular burning of fallow vegetation (Hölscher 1997, Sommer 2000). However, relative to the available nutrient stocks, the high annual losses in this study on relatively fertile soils accounted only for small fractions. This emphasizes the importance of native soil fertility when comparing nutrient budgets between sites.

This was also confirmed when nutrient budgets of natural forests sites from this study were compared to published results. Although nutrient losses in the natural forest systems were low compared to agricultural systems, the overall nutrient balance was still negative. This is in contrast with other studies that also report net nutrient accumulation in rainforest systems, e.g. Forti et al. (1998), who report lower outputs of ions than inputs on soils with low fertility in Amzonia, other examples are studies by Lesack et al. (1996), and Mackensen (1998). Bruijnzeel (1991) also reported accumulation of P in most studies in tropical moist forests, whereas this study did not detect inputs by rain, and therefore calculations resulted in unchanged P stocks in natural forest. However, these studies were all conducted on soils with a relatively low fertility. Given the high fertility of soils, it is not a surprise that nutrient cycles in this study were more open and natural forest sites lost nutrients. This has been suggested before for nutrient balances of natural forests on relatively fertile soils (Vitousek and Sanford, 1986).

Only in location 1 nutrient losses of annual crops (maize) could be directly compared with the perennial (agroforestry) system. Surprisingly, higher nutrient losses were found in the agroforestry systems, not only because nutrient export in harvested products was higher, but also because leaching losses were higher. This is in contrast with the review by Schroth et al. (2001) who report that most studies found lower leaching of nutrients in multi-strata perennial cropping systems compared to annual crops. This result highlights the problem of measuring only partial nutrient balances. In all studies on nutrient balances some nutrient pathways are 
not considered. This is mainly because of methodological problems. Pathways, which might be considerable to the nutrient balance in this study, but were not measured, are biological $\mathrm{N}$ fixation (mainly in agroforestry), deep soil root exploitation (agroforestry and forest), mineral weathering and volatilisation by burning of harvest residuals (maize). Inclusion of these pathways would probably drastically alter the nutrient balances. Nutrient balances therefore should never be compared directly, but always in the context of site differences and potentially missing pathways.

\subsubsection{Pathways of nutrient gain and loss in maize and agroforestry}

Maize yields in this study (around $2 \mathrm{Mg}$ maize ha ${ }^{-1}$ per harvest) were relatively high compared to published numbers for unfertilised systems. Hölscher (1995) measured maize yields of $0.6 \mathrm{Mg} \mathrm{ha}^{-1}$ (unfertilized) and 1.4 $\mathrm{Mg} \mathrm{ha}^{-1}$ (NPK- fertilized) per harvest from field experiments in eastern Amazonia. In this study harvests were achieved after several years of continuous cultivation, and the owners of the plots reported even higher yields in the beginning of cultivation of these plots. Low yields were often blamed on weed infestation or climatic conditions rather than on soil fertility.

Nutrient exports of $\mathrm{P}, \mathrm{K}$ and $\mathrm{Mg}$ in maize harvest differed between the two locations, even though dry weight harvest was similar. This points at some 'luxury consumption' of these nutrients. Soil total $\mathrm{P}$ stocks were much lower and $\mathrm{pH}$ was higher in maize of location 1 (pH 6.5) compared to location 2 ( $\mathrm{pH} 4.6$ ), so that low supply is assumed to be the reason for low $\mathrm{P}$ uptake by maize in location 1 . However, harvest export of $\mathrm{K}$ and $\mathrm{Mg}$ were higher in location 2 although soil stocks were lower compared to location 1.

Although concentrations of N, Ca and $\mathrm{K}$ in rain water were mostly higher or at the top of the range reported in literature (Brouwer 1996, Mackensen 1998), nutrient input by rain replaced only small fractions of nutrient losses in agricultural systems, except for $\mathrm{Na}$ and $\mathrm{K}$. In forest sites rain replaced substantial parts of $\mathrm{N}, \mathrm{K}$ and $\mathrm{Na}$ losses, especially on the poorer soils of location 2. The $\mathrm{pH}$ values were also significantly higher than literature values, whereas $\mathrm{P}, \mathrm{Mg}$ and Na were similar to the median of literature values (Brouwer 1996, Hetzel 1999). Frequent and widespread slash-and-burn activity in the research area, which releases large amounts of wood-ash into the air, probably caused the high $\mathrm{K}$ and $\mathrm{Ca}$ concentrations and $\mathrm{pH}$ in rain water. 
The high annual $\mathrm{N}$ losses of $74 \mathrm{~kg} \mathrm{ha}^{-1}$ in agroforestry contrast with the chronosequence study, where stable or slightly increasing soil C and $\mathrm{N}$ stocks were found during cultivation in agroforestry (see chapter 2). This is indirect evidence of the effect of biological N-fixation by legume shade trees. Results of gross $\mathrm{N}$ transformation activity measurements support this (see chapter 3): in agroforestry, rates of $\mathrm{N}$ mineralisation and $\mathrm{NH}_{4}^{+}$uptake were higher and turnover of the $\mathrm{NH}_{4}{ }^{+}$pool was much faster compared to maize. Biological $\mathrm{N}$ fixation in agroforestry systems with legume shade trees has been reported to be a major input pathway for $\mathrm{N}$ to the systems through litter-fall and prunings, but the amount of $\mathrm{N}$ which is contributed to the system remains unclear. One study reports legume shade trees to supply up to $60 \mathrm{~kg} \mathrm{~N}$ ha $^{-1}$ annually (Beer et al. 1998), and these inputs were exceeding annual harvest exports. Most studies state that the positive effect of the shade trees is not only biological N-fixation, but also organic matter input, control of water evaporation by shading and prevention of erosion (Fassbender 1998). This may explain the result in the chronosequence study of stable soil C stocks in agroforestry. In a study on landscape-scale in Indonesia, increased soil C and aboveground $\mathrm{C}$ levels were found in shaded coffee plantations compared to sun exposed coffee without shade trees (Bruijnzeel 2002).

Given the young age of the soils and the high content of primary minerals, weathering of minerals is expected to be an important supplier of base cations to the systems. However, there are methodological problems to measure this nutrient pathway. Contrary to this study, mineral weathering was not considered an important source of nutrients on relatively poor, deeply weathered soils in East Kalimantan (Mackensen 1998). But of all nutrients only net K losses were a significant proportion of exchangeable $\mathrm{K}$ stocks, and for $\mathrm{K}$ large nonexchangeable pools remain. In the case of soils in Central Sulawesi these stocks may replace losses, as long as export rates are not faster than release by weathering. 


\subsection{Conclusion}

The observed nutrient losses depended more on site conditions than on land use. This highlights that the use of partial nutrient balances as indicators of sustainability may be problematic. When conducting a nutrient balance study, there are always some pathways of nutrient gain or loss which are not quantified. However, depending on the site where the study was conducted these pathways may be critical to understand the observed nutrient losses. Three of the pathways which are almost never measured because of methodological problems, but were important in this study, are $\mathrm{N}$-fixation (agroforestry), deep soil root exploitation (agroforest), and mineral weathering (all studied systems). Partial nutrient balances should therefore never be used directly to draw conclusions of the sustainability of land use systems, but they should always be put into context. In this case the chronosequence study made clear that a considerable $\mathrm{N}$ source ( $\mathrm{N}$-fixation) must compensate the high $\mathrm{N}$-losses observed in agroforestry. However, the chronosequence did not help to draw the same conclusion for base cation nutrients, as the background values were simply too high. That base cations are not critical nutrients became clear from the losses of base cations in the forest sites (which is very unusual), together with the high base saturation of the soils.

The conclusion of this study is that high fertility of soils in Central Sulawesi creates good conditions for permanent agriculture. The only element that can become critical is nitrogen, as it is not released during weathering. Management should therefore be directed at maintaining nitrogen levels. As this is done in agroforestry with legume shade trees, this land use system is sustainable from a nutrient perspective. In time, permanent maize cultivation cannot be continued without external $\mathrm{N}$ inputs and management of soil organic matter. 


\section{5}

\section{Summarizing Synthesis}

Central Sulawesis uplands are characterised by continuing deforestation activity by smallholder farmers, who open forest areas for agriculture. The overall goal of this study was to test the hypothesis that decline in soil fertility causes further deforestation because of declining harvest yields. The study was also aimed at evaluating which one of the major agricultural land use systems is more suitable in terms of nutrient sustainability. Effects of deforestation were studied on soil parameters and nutrient stocks. Additionally nutrient balances and gross $\mathrm{N}$ cycling activity were studied in two major land use systems, maize and cocoa-coffee agroforestry, and compared with natural forest as reference.

\subsection{Effects of forest conversion and continuous agriculture on soil fertility}

Results from the first part of the study showed that soils in the research area are generally fertile, with medium to high $\mathrm{pH}$, high base cation saturation, and large stocks of total $\mathrm{C}$ and N. As expected from previous studies, conversion of rainforest resulted in significantly lower total $\mathrm{C}$ and $\mathrm{N}$ stocks in maize and agroforestry. However, significant differences were found between maize and agroforestry during continuous cultivation in a chronosequence (false time series). During maize cultivation $\mathrm{C}$ and $\mathrm{N}$ stocks declined significantly, whereas in agroforestry $\mathrm{C}$ and $\mathrm{N}$ stocks stayed stable, with a tendency to increase. Farmers usually switched from maize cultivation to agroforestry a few years after conversion of a forest site. This may be an adaptation to reduced N-supply of maize sites after some years of continuous cultivation.

Only few sites with low native soil fertility were found. These sites were regularly burnt grasslands (some, but not all dominated by Imperata cyclindrica), mostly on dystric cambisols. These soils had low pH values, low base cation saturation, and higher Alsaturation of ECEC. These grasslands were generally not used for agriculture, but it is unclear if these sites were the result of past cultivation periods or if they had developed naturally. 
No evidence was found that forest conversion has negative effects on base cation stocks or base cation saturation. Ca-saturation of ECEC even increased in 30-40 cm depth in converted sites. The case study of nutrient input and output balances showed that in agroforestry and maize annual losses of $\mathrm{Mg}$ and $\mathrm{Ca}$ were only small percentages of available soil stocks in the $0-40 \mathrm{~cm}$ soil profile. The only exception was $\mathrm{K}$, where annual net losses were about $15 \%$ in agroforestry and $1 \%$ to $8 \%$ in maize of exchangeable $\mathrm{K}$ stocks in 0-40 cm depth. Consequently, declines of exchangeable $\mathrm{K}$ during cultivation were found in the chronosequence in both agroforestry and maize, but only the latter was statistically significant. However, nonexchangeable stocks of base cations are high, and weathering of minerals on these geologically young soils is hypothesised to replaces base cation losses.

These results indicate that forest conversion in uplands of Central Sulawesi is not driven by declining soil fertility. Sites under cultivation do not show signs of serious degradation. Soil parameters stay stable in agroforestry, and farmers switch from (unsustainable) maize cultivation to agroforestry after some years of harvesting maize. Degraded areas are very rare, there are still relatively large uncultivated areas outside of the forest which could be used.

Furthermore, this study shows that stability of rainforest margins does not nescessarily increase when soils are fertile and land use is sustainable. Farmers may be encouraged to invest into new cropland if rentability is high, and additional farmers may be attracted into apparently fertile areas from other parts of the country. Both factors lead to intensified deforestation. Therefore the hypothesis of declining soil fertility driving forest conversion in Central Sulawesi is rejected.

\subsection{Nutrient sustainability of maize and agroforestry}

Balanced nutrient in- and outputs are crucial for long term sustainability of agricultural land use systems. However, nutrient balance studies have so far mainly focused on nutrient pathways which are relatively easy to measure, and these may not be sufficient to evaluate nutrient sustainability. Results of this study show that other nutrient pathways may be critical to evaluate nutrient sustainability. Future research must focus on studying nutrient 
pathways which have not yet been sufficiently quantified, e.g. biological $\mathrm{N}$ fixing and mineral weathering, to increase significance of nutrient balance studies (Figure 17).

Partial nutrient balances used in this study (chapter 4) resulted in higher $\mathrm{N}$ losses in the agroforestry system compared to maize. However, the chronosequence study did not show decline of soil $\mathrm{N}$ during cultivation in the agroforestry system. This shows that these agroforestry systems combine high outputs and productivity with high $\mathrm{N}$ inputs. Results suggest that $\mathrm{N}_{2}$ - fixing legume shade trees in the agroforestry system contribute $\mathrm{N}$ to the system by prunings and litterfall, balancing the annual net losses of $\mathrm{N}$, whereas unfertilised maize cultivation is mining on soil $\mathrm{N}$ stocks, which developed under natural forest conditions. To stabilize soil $\mathrm{N}$ stocks in the agroforestry system in this case study, biological $\mathrm{N}$ fixation must contribute at least about $74 \mathrm{~kg} \mathrm{~N} \mathrm{ha}^{-1}$ annually (Figure 17). In maize sites results of the chronosequence study show an annual decline of topsoil $\mathrm{N}$ stocks of $2 \%$ (Figure 18), which is about $80 \mathrm{~kg} \mathrm{ha}^{-1} \mathrm{a}^{-1}$ in the case of the maize field of location 1. However, results of the partial nutrient balance show only a annual loss of about $55 \mathrm{ha}^{-1}$. This suggests that there are possibly also additional $\mathrm{N}$ output pathways (volatilisation losses, denitrification), which were not measured in the partial nutrient balance (Figure 17). Also N-losses during the first year following clear cutting have probably been higher than in following years.

Studies of gross $\mathrm{N}$ transformations in natural forest, agroforest and maize (chapter 3) supported these findings of higher $\mathrm{N}$ supply in the agroforestry system than in maize. Inorganic $\mathrm{N}$ pools were higher in natural forest than agroforest and maize, but gross mineralisation and $\mathrm{NH}_{4}{ }^{+}$consumption rates were significantly higher in agroforest than in maize, and not significantly different between agroforestry and natural forest, indicating a sufficient N-supply. $\mathrm{N}$ mineralisation activity of microbial biomass was highest in agroforestry, followed by natural forest and lowest in maize. It was not possible to measure nitrification or $\mathrm{NO}_{3}{ }^{-}$consumption, because there was a rapid immobilisation of $\mathrm{NO}_{3}{ }^{-}$in all three land use systems. This effect may lead to retention of $\mathrm{N}$ in the soil. However, further studies are necessary to investigate to which $\mathrm{N}$ pool the immobilised $\mathrm{NO}_{3}{ }^{-}$has changed, and how long this immobilisation lasts.

Results from the chronosequence study show annual decline of exchangeable $\mathrm{K}$ in the topsoil by $14 \%$ in maize and $6.4 \%$ in agroforestry, this equals losses of about $45 \mathrm{~kg} \mathrm{ha}^{-1} \mathrm{a}^{-}$ ${ }^{1}$ in maize and $14 \mathrm{~kg} \mathrm{ha}^{-1} \mathrm{a}^{-1}$ in agroforestry of location 1 . However, partial nutrient 
balances in this location result in lower $\mathrm{K}$ losses in maize $\left(13 \mathrm{~kg} \mathrm{ha}^{-1} \mathrm{a}^{-1}\right)$ and higher losses in agroforestry (56 kg ha $\mathrm{k}^{-1}$ ). This also may be caused by missing nutrient pathways in the partial balance. In maize, volatilisation of $\mathrm{K}$ by burning harvest residues may be an additional K-export pathway, whereas in agroforestry crop plants can take up nutrients from deeper soil layers, and topsoil changes of nutrient stocks my not be representative (Figure 19).

Contrary to other studies, results showed larger losses through leaching in agroforestry than in maize. But overall the effect of native soil fertility on leaching was stronger than land use. Lower leaching losses were found on more acidic, infertile soils compared to more fertile soils with higher $\mathrm{pH}$.

This study shows that soils in the research region are fertile and suitable for permanent agriculture. If land use systems are not fertilized, agroforestry is a better option in terms of nutrient sustainability compared to maize monoculture. Although maize cultivation is productive at first, production will degrade in time without $\mathrm{N}$ input and management of soil organic matter. This study also highlights the problems with commonly used partial nutrient balance studies. These studies are unsuitable to evaluate nutrient sustainability in land use systems if important nutrient pathways are not measured.

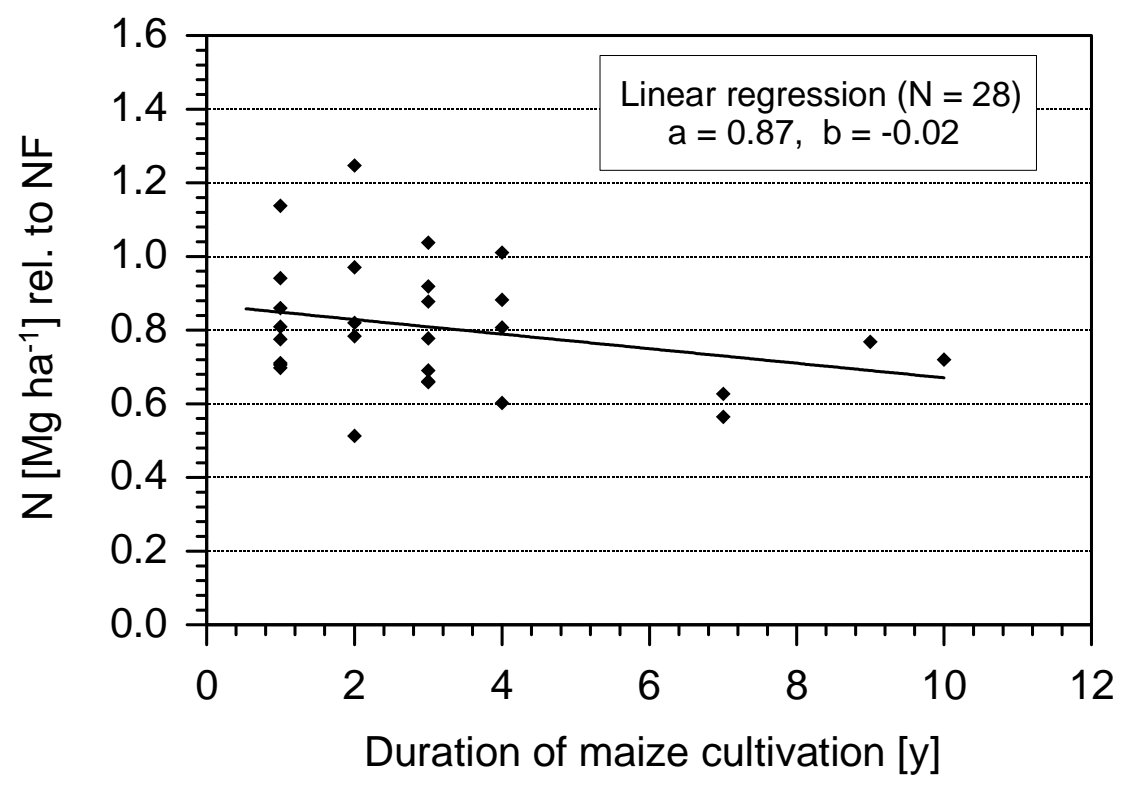

Figure 19. Linear regression of standardised $\mathrm{N}$ stocks in a maize chronosequence. 

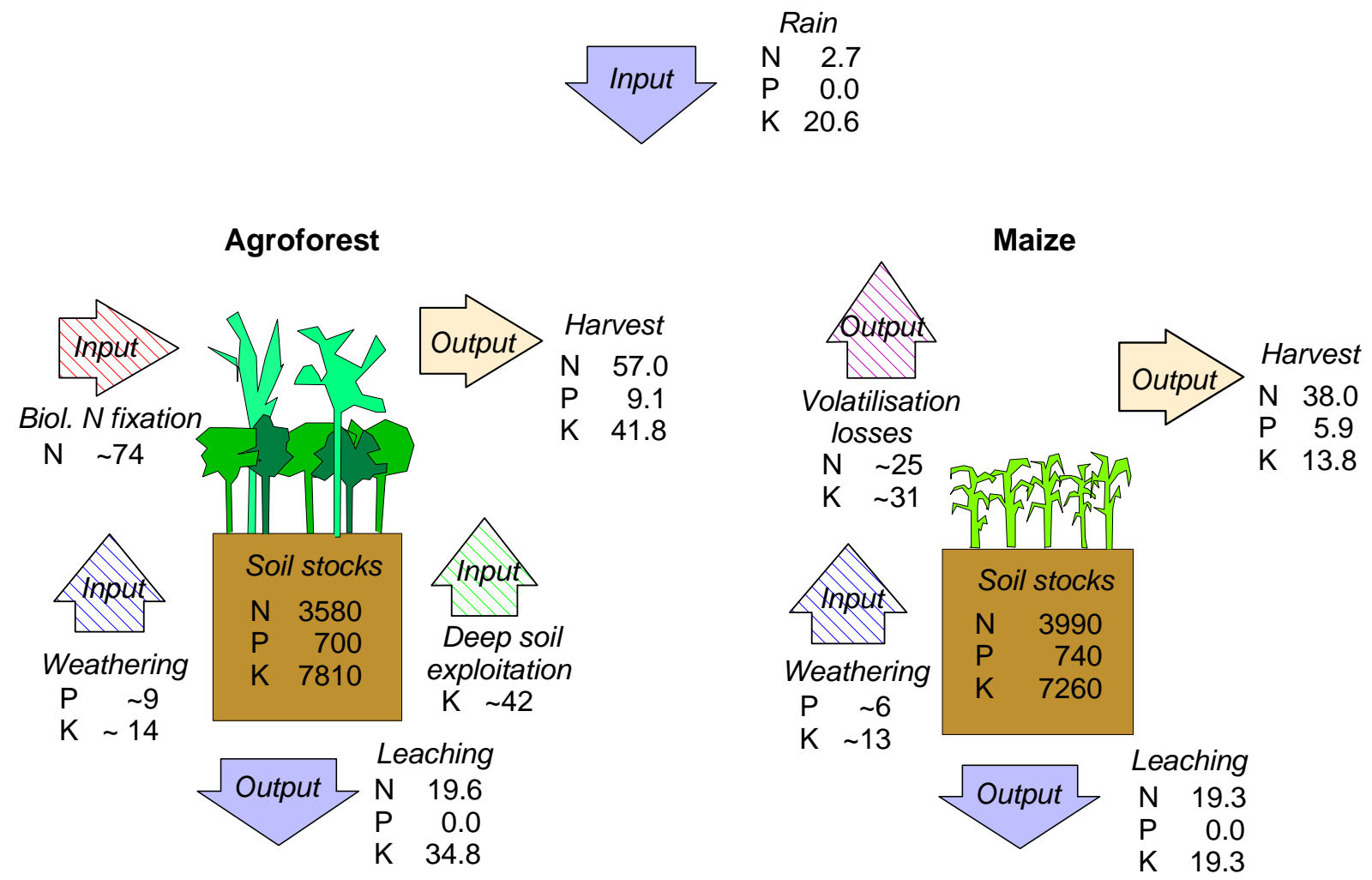

Figure 20. Nutrient balance of agroforestry and maize. Solid arrows indicate measured fluxes, hatched arrows indicate nutrient fluxes that were not measured, but estimated based on indirect evidence (see text). Soil stocks are in $\mathrm{kg} \mathrm{ha}^{-1}$, all fluxes in $\mathrm{kg} \mathrm{ha}^{-1} \mathrm{a}^{-1}$. 


\section{Summary}

Changes of soil fertility after rainforest conversion and nutrient sustainability in major land use systems were studied in rainforest margins in uplands of Central Sulwesi, Indonesia. The research area was characterised by continuing deforestation activity, mostly by smallholders. The study was devided in three parts: A) Influence of land use system and duration of maize- and agroforestry cultivation on soil parameters was studied, B) gross $\mathrm{N}$ transformation rates in natural forest, agroforest and maize were measured, and C) a case study of input-output balances of nutrients was conducted.

A survey of 74 sites of 5 major land-use systems (maize fields, agroforestry, forest fallow, grass fallow and natural forest) showed that soils in the research region were generally fertile, with high base cation saturation, high cation exchange capacity, medium to high $\mathrm{pH}$-values and sufficient stocks of nitrogen. Conversion of natural forest to both maize and agroforestry reduced topsoil $\mathrm{C}$ and $\mathrm{N}$ stocks by about $20 \%$ compared to natural forest, but during continuous maize cultivation $\mathrm{C}$ and $\mathrm{N}$ stocks declined further, whereas in agroforestry levels stayed stable. These results indicate that agroforestry was the better land use option in terms of nutrient sustainability compared to maize. The study shows that legume shade trees are an important compartment of the agroforestry system, replacing $\mathrm{N}$ losses and keep soil organic matter stocks stable. This was supported by measurements of gross $\mathrm{N}$ transformation processes, which showed higher gross mineralisation, $\mathrm{NH}_{4}{ }^{+}$uptake, and faster turnover of $\mathrm{N}$ in agroforestry systems than in maize. Results showed fast immobilisation of $\mathrm{NO}_{3}{ }^{-}$, which may lead to retention of $\mathrm{N}$ in the soil.

Bulk density and base cation saturation was higher on converted sites than in natural forest, during cultivation of maize bulk density increased, whereas in agroforestry it stayed stable. Grass fallows had lowest $\mathrm{pH}$ and ECEC. The nutrient balances case study (nutrient input by precipitation and output by leaching and harvest) showed negative balances for all nutrients in forest, agroforest and maize, except for $\mathrm{K}$ and $\mathrm{P}$ in natural forest. $\mathrm{N}, \mathrm{K}$ and $\mathrm{P}$ losses occurred mainly via harvest, $\mathrm{Ca}$, $\mathrm{Na}$ and $\mathrm{Mg}$ losses mainly by leaching. Precipitation replaced only small fractions of $\mathrm{N}$ but larger parts of $\mathrm{Na}$ and $\mathrm{K}$ losses in agricultural sites. Although the partial nutrient balances were more negative for agroforestry than maize, nutrients were replaced through pathways which were not measured (biological N-fixation, 
weathering). This shows that partial nutrient balances alone should not be used to evaluate sustainability of land use systems.

\subsection{Zusammenfassung}

In dieser Studie wurden Veränderungen von Bodenparametern nach Brandrodung des Regenwaldes in Zentral-Sulawesi, Indonesien, untersucht. Zusätzlich wurde die Nachhaltigkeit verschiedener Landnutzungssysteme in Bezug auf die Bodenfruchtbarkeit bewertet. Das Untersuchungsgebiet ist durch fortschreitende Waldumwandlung, hauptsächlich durch Kleinbauern, geprägt. Die Studie wurde in 3 Teile gegliedert: Im ersten Teil (A) wurde der Einfluss des Landnutzungssystems und der Anbaudauer auf verschiedene Bodenparameter untersucht. Im zweiten Teil (B) wurden bruttoTransformationsprozesse von $\mathrm{N}$ in Naturwald, Agroforst und Mais gemessen und verglichen. Im dritten Teil (C) wurden die Nährstoffein- und austräge in Naturwald, Mais und Agroforst in einer Fallstudie gemessen. Mit diesen Informationen wurden Nährstoffbilanzen für diese Systeme erstellt.

Im Teil (A) wurde ein Bodensurvey durchgeführt. Insgesamt wurden 74 Flächen von 5 Landnutzungssysteme (Naturwald, Waldbrache, Agroforst, Mais und Grasbrache) untersucht. Die Ergebnisse zeigten, dass die Böden des Untersuchungsgebietes generell fruchtbar waren. Basensättigung, $\mathrm{pH}-$ Werte, KAK und Gesamt-C und -N Vorräte waren relativ hoch.

Umwandlung von Regenwald in Agroforst oder Maisfelder verursachte einen Rückgang der Oberbodenvorräte von $\mathrm{C}$ und $\mathrm{N}$ um etwa 20 \% im Vergleich zum Naturwald, im Maisanbau nahmen allerdings die C und N Vorräte während des Anbaus weiter ab, während sie im Agroforst-system stabil blieben. Diese Ergebnisse bestätigten die Annahme, dass Agroforstsysteme nachhaltiger in Bezug auf die Bodenfruchtbarkeit sind als der kontinuierliche Maisanbau. Ausserdem konnte der positive Einfluss von $\mathrm{N}_{2^{-}}$ fixierende Leguminosen als Schattenbäume im Agroforstsystem belegt werden. Die Leguminosen gleichen $\mathrm{N}$ Verluste aus und stabilisieren die organische Substanz des Bodens. Diese Ergebnisse des Bodensurveys konnten zusätzlich durch die Messungen der 
brutto N Transformationsprozesse (B) bestätigt werden. Agroforstsysteme hatten höhere $\mathrm{N}$-Mineralisation, $\mathrm{NH}_{4}{ }^{+}$-Aufnahme und schnelleren $\mathrm{N}$-Umsatz als die Maisflächen.

Trockenraumdichte und Basensättigung auf umgewandelten Flächen waren höher als im ungestörten Naturwald. Bei andauerndem Maisanbau stieg die Trockenraumdichte, während sie im Agroforstsystem stabil blieb. Grasbrachen hatten niedrigste pH- Werte und KAK.

Die Fallstudie der Nährstoffbilanzen (C) in Mais, Agroforst und Naturwald (Einträge durch Regen und Austräge durch Auswaschung und Ernteentzug) zeigte negative Bilanzen für alle Makronährstoffe sowohl im Naturwald, als auch in Mais und Agroforst. Nur für P und K waren im Naturwald keine Verluste zu verzeichnen. Wichtigster Austragsmechanismus für N, P und $\mathrm{K}$ war Ernteentzug, während $\mathrm{Ca}$, $\mathrm{Mg}$ und $\mathrm{Na}$ hauptsächlich durch Auswaschung verloren gingen. Regen ersetzte nur geringe Anteile des verlorenen N, aber durchaus bedeutsame Anteile des verlorenen Na und K.

Die partiellen Nährstoffbilanzen ergaben zwar höhere Verluste für das Agroforstsystem als im Mais, jedoch müssen die nicht gemessenen Nährstoffflüsse berücksichtigt werden. Diese Flüsse ersetzen wahrscheinlich zumindest teilweise die netto Verluste, die in der partiellen Bilanz errechnet werden. Dies zeigt deutlich, dass partielle Nährstoffbilanzen alleine nicht geeignet sind, um die Nachhaltigkeit von Landnutzungssystemen zu bewerten. 


\section{References}

Andriesse, J.P., 1977. Nutrient level changes during a 20 year shifting cultivation cycle in Sarawak (Malaysia). In: Proceedings, conference on classification and management of tropical soils, Kuala Lumpur, Malaysian Society of Soil Science. pp: 479-491.

Andriesse, J.P, Schelhaas, R.M., 1987. A monitoring study of nutrient cycles in soils used for shifting cultivation under various climatic conditions in tropical Asia. II. Nutrient stores in biomass and soil- results of baseline studies. Agriculture, Ecosystems and Environment 19: 285-310.

Beer, J., Muschler, R., Kass, D., Somarriba, E., 1998. Shade management in coffee and cocoa plantations. Agroforestry Systems 38: 139-164.

Berntson, G.M., Aber, J.D., 2000. Fast nitrate immobilization in N saturated temperate forest soils. Soil Biology and Biochemistry 32: 151-156.

Brookes, P.C., Landman, A.G., Pruden, G., Jenkinson, D.S., 1985. Chloroform fumigation and the release of soil nitrogen: a rapid direct extraction method to measure microbial biomass nitrogen in soil. Soil biology and biochemistry 17: 837-842.

Brouwer, L., 1996. Nutrient cycling in pristine and logged tropical rain forest- a study in Guyana. Tropenbos Guyana series 1.

Bruijnzeel, L.A., 1990. Hydrology of moist tropical forests and effects of conversion: A state of knowledge review. UNESCO, University of Amsterdam. Publication of the humid tropics programme.

Bruijnzeel, L.A., 1991. Nutrient input-output budgets of tropical forest ecosystems: a review. Journal of Tropical Ecology 7: 1-24. 
Bruijnzeel, L.A., 1995. Predicting the hydrological impacts of land cover transformation in the humid tropics, the need for integrated research. In: Gash, H., Nobre, C., Roberts, J., Victoria, R. (Eds). Amazonian deforestation and climate. J. Wiley, New York.

Bruijnzeel, L.A.. 2002. Carbon stock assessment for a forest-to-coffee conversion landscape in Sumber-Jaya (Lampung, Indonesia): from allometric equations to land use change analysis. Science in China, series C: Life Sciences. October 2002, 45 Suppl.: 75-86.

Compton, J.E., Boone, R.D., 2002. Soil nitrogen transformations and the role of light fraction organic matter in forest soils. Soil Biology and Biochemistry 34: 933-943.

Corre, M. D., Schnabel, R. R., Stout, W. L., 2002. Spatial and seasonal variation of gross nitrogen transformations and microbial biomass in a northeastern US grassland. Soil Biology and Biochemistry 34: 445-457.

Corre, M.D., Beese, F., Brumme, R., 2003. Soil nitrogen cycle in high nitrogen deposition forest: Changes under nitrogen saturation and liming. Ecological Applications 13 (2): 287-298.

Dail, D., Davidson, E.A., Chorover, J., 2001. Rapid abiotic transformation of nitrate in an acid forest soil. Biogeochemistry 54: 131-146.

Davidson, E.A., Eckert, R.W., Hart, S.C., Firestone, M.K., 1989. Direct extraction of microbial biomass $\mathrm{N}$ from forest and grassland soils of California. Soil Biology and Biochemistry 21: 773-778.

Davidson, E.A., Stark, J.M., Firestone, M.K., 1990. Microbial production and consumption of nitrate in an annual grassland. Ecology 71: 1968-1975.

Davidson, E.A., Hart, S.C., Shanks, C.A, Firestone, M.K., 1991. Measuring gross nitrogen mineralization, immobilisation, and nitrification by ${ }^{15} \mathrm{~N}$ isotopic pool dilution in intact soil cores. Journal of Soil Science 42: 335-349. 
Davidson, E., Ackerman I., 1993. Changes in soil carbon inventories following cultivation of previously untilled soils. Biogeochemistry 20: 161-193.

Davidson, E.A., Chorover, A.J., Dail, D.B., 2003. A mechanism of abiotic immobilization of nitrate in forest ecosystems: the ferrous wheel hypothesis. Global Change Biology 9: 228-236.

FAO, 1998a. World reference for soil resources. World soil resources reports 84, FAO, Rome.

FAO, 1998b. Crop evapotranspiration. Guidelines for computing crop water requirements. Allen R., Pereira L., Raes D., Smith M. FAO irrigation and drainage papers 56.

FAO, 2001. FAO statistical databases 2001. FAO, Rome.

Fassbender, H., 1989. Long term studies of soil fertility in cocoa-shade trees agroforestry systems: Results of 15 years of organic matter and nutrient research in Costa Rica. Soils of tropical forest ecosystems. Schulte, A., Ruhiyat, D. (Eds). Springer Verlag Berlin, Heidelberg, New York.

Finck, A., 1963. Tropische Böden. Paul Parey, Hamburg and Berlin.

Fisher, M., Rao I., Ayarza, M., 1994. Carbon storage by introduced deep-rooting grasses in the South American savannas. Science 371: 236-238.

Forti, C., Moreira-Nordemann, L., 1998. An ion budget for a terra firma rainforest in Central Amazonia. In: Water management of the Amazon basin. Braga, B. and FernandezJauregani, C. (Eds). Unesco, Paris.

Garcia-Montiel, D.C., Binkley, D., 1998. Effect of Eucalyptus saligne and Albizia falcataria on soil processes and nitrogen supply in Hawaii. Oecologia 113: 547-556. 
Guo, L.B., Gifford, R.M., 2002. Soil carbon stocks and land use change: a meta analysis. Global Change Biology 8: 345-360.

Hart, S.C., Stark, J.M., Davidson, E. A., Firestone, M. K., 1994. Nitrogen mineralization, immobilisation and nitrification. In: Weaver, R. (Eds). Methods of soil analysis, Part 2. Microbiological and Biochemical properties. SSSA Book series, No. 5. American Society of Agronomy, Madison, WI, pp. 985-1019.

Heinrichs, H., 1989. Aufschlussverfahren in der analytischen Geochemie (1). Labor Praxis 12: $1140-1146$.

Hetzel, F., 1999. The nutrient and water cycle in tropical rain forest and a cocoa plantation in Cote d'Ivoire. Ecoregio 2.

Hölscher, D., 1995. Wasser und Stoffhaushalt eines Agrarökosystems mit Waldbrache im östlichen Amazonasgebiet. Göttinger Beiträge zur Land- und Forstwirtschaft in den Tropen und Subtropen 106.

Hölscher, D., Möller, R., Denich, M., Fölster, H., 1997. Nutrient input-output budget of shifting agriculture in Eastern Amazonia. Nutrient cycling in Agroecosystems 47: 4957.

Hughes, R., Kauffman, J., Jaramillo, V., 2000. Ecosystem scale impact of deforestation and land use in a humid tropical region of Mexico. Ecological Applications 10(2), 515-527.

Joergensen, R.G., 1996. The fumigation-extraction method to estimate soil microbial biomass: calibration of the KEC value. Soil Biology and Biochemistry 28: 25-31.

Kauffman, B.J., Cummings, D.L., Ward, D.E., 1998. Fire in the Amazon 2. Biomass, nutrient pools and losses in cattle pastures. Oecologia 113: 415-427. 
Kirkham, D., Bartholomew, W.V., 1954. Equations for following nutrient transformations in soil, utilization tracer data. Soil Science Society of America Proceedings 18: 33-34.

Klinge, R., 1998. Wasser- und Nährstoffdynamik im Boden und Bestand beim Aufbau einer Holzplantage im östlichen Amazonasebiet. Göttinger Beiträge zur Land- und Forstwirtschaft in den Tropen und Subtropen 122.

Lanly, J., 1985. Defining shifting cultivation. Contribution to the IX. World Forestry Congress, Mexico 1985. Unasylva 147.

Lawrence, D., Schlesinger, W., 2001. Changes in soil phosphorous during 200 years of shifting cultivation in Indonesia. Ecology 82: 2769-2780.

Lesack, L., Melack, J., 1996. Mass balance of major solutes in a rainforest catchment in the Central Amazon: Implications for nutrient budgets in tropical rainforests. Biogeochemistry 32: 115-142.

Mackensen, J., 1998. Untersuchungen zur nachhaltigen Nährstoffversorgung in schnellwachsenden Plantagenökosystemen in Ost-Kalimantan, Indonesien ökologische und ökonomische Implikationen. Göttinger Beiträge zur Land- und Forstwirtschaft in den Tropen und Subtropen 127.

McGrath, D., Smith, C., Gholz, H., de Assis, O., 2001. Effects of land-use change on soil nutrient dynamics in Amazonia. Ecosystems 4 (7): 625-645.

Meiwes, K., Hauhs, M., Gerke, H., Asche, N., Matzner, E., Lamersdorf, N., 1984. Chemische Untersuchungsverfahren für Mineralböden. Berichte des Forschungs-zentrums Waldökosysteme 7.

Nömmik, H., Vathras, K., 1982. Retention and fixation of ammonium and ammonia in soils. In: Stevenson, F. (Eds), Nitrogen in agricultural soils. American Society of Agronomy, Madison, WI, pp. 123-171. 
Nye, P., Greenland, D., 1965. The soil under shifting cultivation. Technical communication 51, Commonwealth Bureau of Soils, Harpenden, UK.

Paul, E. A., Clark, F. E., 1989. Soil microbiology and biochemistry. Academic Press, New York, USA.

Post, W., Kwon, K., 2000. Soil carbon sequestration and land-use change: processes and potential. Global Change Biology 6: 317-327.

Reiners, W., Bouwman, A., Parsons, W., Keller, M., 1994. Tropical rain forest conversion to pasture: Changes in vegetation and soil properties. Ecological Applications 4(2): 363377.

Richter, D.D., Babbar, L.I., 1991. Soil diversity in the tropics. Advances in Ecological Research 21: 315-389.

Sanchez, P.A., Logan, T.J., 1992. Myths and Science about the Chemistry and Fertility of Soils in the Tropics. In: R. Lal and P.A. Sanchez (Eds), Myths and Science of Soils of the Tropics. SSSA Special Publication. SSSA, Madison, Wisconsin, USA, pp. 35-46.

Schlesinger, W., 1986. Changes in soil carbon storage and associated properties with disturbance and recovery. In: Trabalka J. and Reichle D. (Eds) The changing carbon cycle. A global analysis. Springer, NY, pp. 194-220.

Scholz, U., 2001. The change from shifting cultivation to alternative farming systems in Sumatra. Proceedings Deutscher Tropentag 2001, conference on international agricultural research, University of Bonn.

Schroth, G., Lehmann, J., Rodrigues, M., Barros, E., Macedo, J., 2001. Plant-soil interactions in multistrata agroforestry in the humid tropics. Agroforestry systems 53: 85-102. 
Schroth, G., D’Angelo, S., Teixeira, W., Haag, D., Lieberei, R., 2002. Conversion of secondary forest into agroforestry and monoculture plantations in Amazonia: Consequences for biomass, litter and soil carbon stocks after 7 years. Forest Ecology and Management 163: 131-150.

Shen, S. M., Pruden, G., Jenkinson, D. S., 1984. Mineralization and immobilization of nitrogen in fumigated soil and the measurement of the microbial biomass nitrogen. Soil Biology and Biochemistry 16: 437-444.

Sommer, R., 2000. Water and nutrient balance in deep soils under shifting cultivation with and without burning in the eastern amazon. Dissertation University of Göttingen, Cuvillier, Göttingen.

Stark, J. M., Hart, S. C., 1996. Diffusion technique for preparing salt solutions, kjeldahl digests, and persulfate digests for nitrogen-15 analysis. Soil Science Society of America Journal 60: 1846-1855.

Stienstra, A. W., Klein-Gunnewiek, P., Laanbroek, H. J., 1994. Repression of nitrification under soils of climax grassland vegetation. FEMS Microbiology Ecology 14: 45-52.

Van Rheenen, T., Elbel C., Schwarze, S., Nuryartono, N., Zeller M. (in press). Encroachments into Primary Forests: Are they really driven by despair. In: Land Use, Nature Conservation and the Stability of Rainforest Margins in Southeast Asia, Springer, Berlin.

Veldkamp, E., 1994. Organic carbon turnover in three tropical soils under pasture after deforestation. Soil Science Society of America Journal 58: 175-180.

Veldkamp, E., Davidson, E., Erickson, M., Keller, M., Weitz, A., 1999. Soil nitrogen cycling and nitrogen oxide emissions along a pasture chronosequence in the humid tropics of Costa Rica. Soil Biology and Biochemistry 31: 387-399. 
Veldkamp, E. (in press): Changes in soil carbon stocks following conversion of forest to pasture in the tropics. In: Holland, E.A. (Eds): Notes from Underground: Soil Processes and Global Change. NATO ASI Series. Springer, Berlin.

Vitousek, P., Sanford, R., 1986. Nutrient cycling in moist tropical forest. Annual Review of Ecological Systems 17: 137-167. 


\section{Appendix}

Table 20. Soil survey data, 0-10 $\mathrm{cm}$ depth, means and SD ( $\mathrm{n}=3)$, (texture analysis from 1 composite sample).

\begin{tabular}{|c|c|c|c|c|c|c|c|c|c|c|c|c|c|c|}
\hline \multirow[t]{2}{*}{ No. } & \multirow[t]{2}{*}{ Vill. } & \multirow[t]{2}{*}{ LUS } & \multirow{2}{*}{$\begin{array}{c}\text { Age } \\
\mathbf{y}\end{array}$} & \multirow{2}{*}{$\begin{array}{l}\text { Soil } \\
\text { type }\end{array}$} & \multirow{2}{*}{$\begin{array}{l}\text { BD } \\
\mathrm{g} \mathrm{cm}^{-3}\end{array}$} & \multirow{2}{*}{$\begin{array}{r}\text { Clay } \\
\%\end{array}$} & \multirow{2}{*}{$\begin{array}{r}\text { Sand } \\
\%\end{array}$} & \multirow{2}{*}{$\begin{array}{r}\text { Silt } \\
\%\end{array}$} & \multicolumn{2}{|c|}{ pH (KCl) } & \multicolumn{2}{|c|}{$\mathrm{C} \mathrm{mg} \mathrm{g}^{-1}$} & \multicolumn{2}{|c|}{$\mathrm{N} \mathrm{mg} \mathrm{g}^{-1}$} \\
\hline & & & & & & & & & mean & SD & mean & SD & mean & SD \\
\hline 1 & 1 & 1 & & 1 & 1.15 & 16.4 & 46.7 & 36.9 & 4.8 & 0.3 & 27.7 & 3.5 & 2.5 & 0.2 \\
\hline 2 & 1 & 1 & & 1 & 1.01 & n.m. & n.m. & n.m. & 5.0 & 0.5 & 41.8 & 5.6 & 3.5 & 0.4 \\
\hline 3 & 1 & 2 & & 1 & 0.93 & 7.2 & 71.5 & 21.3 & 4.4 & 0.3 & 27.1 & 4.6 & 2.3 & 0.3 \\
\hline 4 & 1 & 2 & 5 & 1 & 1.03 & 22.8 & 39.9 & 37.3 & 4.4 & 0.3 & 32.1 & 5.2 & 2.9 & 0.8 \\
\hline 5 & 1 & 3 & 10 & 2 & 1.01 & n.m. & n.m. & n.m. & 5.1 & 0.2 & 30.5 & 2.8 & 2.7 & 0.2 \\
\hline 6 & 1 & 4 & 2 & 1 & 1.21 & 6.8 & 71 & 22.2 & 5.5 & 0.2 & 24.4 & 0.6 & 1.9 & 0.1 \\
\hline 7 & 1 & 4 & 2 & 1 & 1.21 & 10 & 43.1 & 46.9 & 4.4 & 0.1 & 23.3 & .9 & 2.0 & 0.1 \\
\hline 8 & 1 & 4 & 10 & 2 & 1.21 & n.m. & n.m. & n.m. & 4.8 & 0.1 & 18.2 & .7 & 1.7 & 0.1 \\
\hline 9 & 1 & 4 & 1 & 2 & 1.15 & 15.2 & 25.4 & 59.4 & 4.7 & 0.1 & 21.6 & 1.5 & 2.1 & 0.2 \\
\hline 10 & 1 & 4 & 2 & 1 & 0.94 & 15.2 & 53.4 & 31.4 & 4.5 & 0.3 & 23.5 & 12.5 & 1.6 & 0.8 \\
\hline 11 & 1 & 5 & & 2 & 1.14 & n.m. & n.m. & n.m. & 4.3 & 0.0 & 19.8 & 10.1 & 2.0 & 0.9 \\
\hline 12 & 2 & 1 & & 1 & 0.72 & 21.6 & 51.3 & 27.1 & 5.8 & 0.3 & 62.8 & 12.9 & 5.8 & 1.2 \\
\hline 13 & 2 & 1 & & 1 & 0.94 & 18 & 51.5 & 30.5 & 5.2 & 0.3 & 31.9 & 1.7 & 3.2 & 0.1 \\
\hline 14 & 2 & 2 & 2 & 1 & 1.20 & 9.2 & 47 & 43.8 & 5.7 & 0.1 & 23.7 & 1.9 & 2.5 & 0.2 \\
\hline 15 & 2 & 3 & 7 & 1 & 1.41 & 13.2 & 57 & 29.8 & 4.7 & 0.3 & 15.3 & 2.3 & 1.2 & 0.2 \\
\hline 16 & 2 & 3 & 4 & 2 & 1.29 & 10 & 37.7 & 52.3 & 4.7 & 0.1 & 17.9 & 1.1 & 2.1 & 0.1 \\
\hline 17 & 2 & 4 & 4 & 1 & 1.1 & 12 & 46.7 & 41.3 & 5 & 0.4 & 25.4 & 1.3 & 2.5 & 0.2 \\
\hline 18 & 2 & 4 & 7 & 1 & 1.42 & 12.8 & 50.5 & 36.7 & 9 & 2 & 16.2 & 1.8 & 1.4 & 0.2 \\
\hline 19 & 2 & 4 & 1 & 1 & 1.1 & 8.8 & 45.3 & 45.9 & 6 & 0.5 & .5 & 3.1 & 2.3 & 0.4 \\
\hline 20 & 2 & 4 & 7 & 1 & 1.4 & 12.8 & 52.7 & 34.5 & & 0.2 & 14 & 3.1 & .6 & 0.3 \\
\hline 21 & 3 & 1 & & 1 & 1.0 & 12.8 & 54.6 & 32.6 & $5 .($ & 0.5 & 25.9 & 6.0 & 2.6 & 0.6 \\
\hline 22 & 3 & 1 & & 1 & 1.03 & 29.6 & 34.2 & 36.2 & & 0. & 30.3 & 7.5 & 2.8 & 0.6 \\
\hline 23 & 3 & 1 & & 1 & 0.68 & n.m. & n.m. & n.m. & 4.2 & 0.2 & 59.6 & 11.7 & 4.4 & 0.8 \\
\hline 24 & 3 & 2 & 2 & 1 & 1.10 & 18.4 & 45.5 & 36.1 & 4.5 & 0.3 & 24.0 & 2.2 & 2.2 & 0.2 \\
\hline 25 & 3 & 2 & 3 & 1 & 1.20 & 12.4 & 54.4 & 33.2 & 5.0 & 0.5 & 18.4 & 9.0 & 1.7 & 0.8 \\
\hline 26 & 3 & 3 & 7 & 1 & 1.37 & n.m. & n.m. & n.m. & 5.0 & 0.6 & 22.4 & 4.7 & 1.9 & 0.3 \\
\hline 27 & 3 & 3 & 2 & 1 & 1.3 & n.m. & n.m. & n.m. & 4.2 & 0.1 & 16.3 & 0.6 & 1.2 & 0.1 \\
\hline 28 & 3 & 3 & 3 & 1 & 1.32 & 12.0 & 60.4 & 27.6 & 4.3 & 0.2 & 15.2 & 1.5 & 1.3 & 0.1 \\
\hline 29 & 3 & 3 & 4 & 1 & 1.24 & 12.0 & 56.4 & 31.6 & 5.5 & 0.2 & 21.0 & 1.8 & 1.6 & 0.1 \\
\hline 30 & 3 & 3 & 8 & 1 & 1.28 & 12.4 & 54.5 & 33.1 & 5.0 & 0.2 & 21.3 & 1.4 & 1.7 & 0.1 \\
\hline 31 & 3 & 4 & 3 & 1 & 1.27 & n.m. & n.m. & n.m. & 4.7 & 0.2 & 17.4 & 1.4 & 1.5 & 0.1 \\
\hline 32 & 3 & 4 & 3 & 1 & 1. & 12.0 & 59.5 & 28.5 & 4.6 & 0.2 & 18 & 0.7 & 1.4 & 0.1 \\
\hline 33 & 3 & 4 & 3 & 1 & 1.2 & 11.2 & 57.6 & 31.2 & 4. & 0.7 & 20 & 2.8 & 1.5 & 0.1 \\
\hline 34 & 3 & 4 & 1 & 1 & 1.0 & 17.2 & 47.1 & 35.7 & 4. & $1 .($ & 25.9 & 2.2 & 1.9 & 0.0 \\
\hline 35 & 3 & 4 & 1 & 1 & 1.1 & 12.4 & 59 & 28.6 & 5.2 & 1.5 & 20.0 & 0.2 & 1.7 & 0.2 \\
\hline 36 & 3 & 5 & 1 & 1 & 1.0 & 17.6 & 33.6 & 48.8 & 4.2 & 0.4 & 26.7 & 4.1 & 2.3 & 0. \\
\hline 37 & 4 & 1 & & 2 & 1.1 & 14.4 & 69.6 & 16 & 5.7 & 0.5 & 41.0 & 6.0 & 3.4 & 0.4 \\
\hline 38 & 4 & 1 & & 2 & 1.07 & 20.8 & 49.4 & 29.8 & 4.5 & 0.4 & 29.1 & 2.5 & 2.9 & 0.3 \\
\hline 39 & 4 & 1 & & 2 & 1.12 & n.m. & n.m. & n.n & 5.8 & 1.0 & 38.1 & 7.9 & 3.7 & 0. \\
\hline 40 & 4 & 2 & 4 & 2 & 0.98 & 16 & 61.9 & 22.1 & 5.9 & 0.2 & 43.0 & 4.5 & 3.8 & 0.2 \\
\hline 41 & 4 & 2 & & 2 & 1.10 & 22.8 & 51.3 & 25.9 & 5.6 & 0.3 & 32.0 & 5.0 & 3.1 & 0.4 \\
\hline 42 & 4 & 2 & & 3 & 0.99 & 28 & 26.6 & 45.4 & 4.9 & 0.4 & 38.2 & 8.0 & 3.8 & 0.8 \\
\hline 43 & 4 & 2 & 2 & 1 & 1.10 & 15.6 & 59.2 & 26.2 & 6.0 & 0.2 & 38.0 & 2.4 & 3.2 & 0.0 \\
\hline 44 & 4 & 2 & 10 & 2 & 1.05 & 25.6 & 18.2 & 56.2 & 5.1 & 0.2 & 34.1 & 4.2 & 2.9 & 0.2 \\
\hline
\end{tabular}




\begin{tabular}{|c|c|c|c|c|c|c|c|c|c|c|c|c|c|c|}
\hline \multirow[t]{2}{*}{ No. } & \multirow[t]{2}{*}{ Vill. } & \multirow[t]{2}{*}{ LUS } & \multirow{2}{*}{$\begin{array}{c}\text { Age } \\
\text { y }\end{array}$} & \multirow{2}{*}{$\begin{array}{l}\text { Soil } \\
\text { type }\end{array}$} & \multirow{2}{*}{$\begin{array}{c}\text { BD } \\
\mathrm{g} \mathrm{cm}^{-3}\end{array}$} & \multirow{2}{*}{$\begin{array}{r}\text { Clay } \\
\%\end{array}$} & \multirow{2}{*}{$\begin{array}{r}\text { Sand } \\
\%\end{array}$} & \multirow{2}{*}{$\begin{array}{r}\text { Silt } \\
\%\end{array}$} & \multicolumn{2}{|c|}{ pH (KCl) } & \multicolumn{2}{|c|}{$\mathrm{C} \mathrm{mg} \mathrm{g}^{-1}$} & \multicolumn{2}{|c|}{$\mathbf{N} \mathbf{m g ~ g}^{-1}$} \\
\hline & & & & & & & & & mean & SD & mean & SD & mean & SD \\
\hline 45 & 4 & 3 & 3 & 2 & 1.22 & n.m. & n.m. & n.m. & 5.0 & 0.1 & 23.4 & 1.4 & 2.3 & 0. \\
\hline 46 & 4 & 3 & 6 & 3 & 1.06 & 28.4 & 33.4 & 38.2 & 4.7 & 0.3 & 35.5 & 2.8 & & 0.2 \\
\hline 47 & 4 & 3 & 4 & 2 & 1.06 & 31.2 & 13.2 & 55.6 & 5.5 & 0.1 & 47.7 & 6.0 & 4 & \\
\hline 48 & 4 & 3 & 4 & 2 & 1.11 & 6.8 & 53.8 & 39.4 & 5.3 & 0.1 & 23.6 & 1.1 & 2 & \\
\hline 49 & 4 & 3 & 3 & 2 & 1.21 & n.m. & n.m. & n.m. & 4.3 & 0.2 & 15.2 & 3.6 & & 0. \\
\hline 50 & 4 & 3 & 6 & 2 & 1.14 & n.m. & n.m. & n.m. & 5.7 & 0.3 & 32.2 & 7.9 & 3 & 0. \\
\hline 51 & 4 & 4 & 4 & 2 & 1.21 & 15.2 & 45.2 & 39.6 & 5.7 & 0.1 & 31.4 & 2.9 & 2.5 & 0.3 \\
\hline 52 & 4 & 4 & 1 & 3 & 1.06 & 28.8 & 28.6 & 42.6 & 4.1 & 0.0 & 33.4 & 1.1 & 3.1 & 0.2 \\
\hline 53 & 4 & 4 & 3 & 3 & 0.94 & 20.8 & 39.2 & 40 & 4.7 & 0.4 & 37.3 & 3.7 & $2 . \varepsilon$ & 0.3 \\
\hline 54 & 4 & 4 & 2 & 3 & 0.99 & 24 & 28.6 & 47.4 & 4.9 & 0.1 & 34.3 & 3.6 & 3. & 0.3 \\
\hline 55 & 4 & 4 & 4 & 2 & 1.19 & 17.6 & 51.6 & 30.8 & 4.9 & 0.0 & 27.0 & 2.3 & 2. & 0. \\
\hline 56 & 4 & 4 & 1 & 2 & 0.87 & 29.2 & 25.9 & 44.9 & 4.5 & 0.2 & 37.7 & 5.1 & 3. & \\
\hline 57 & 4 & 4 & 1 & 2 & 1.11 & 11.6 & 61.6 & 26.8 & 5.2 & 0.2 & 23.6 & 0.5 & 2. & \\
\hline 58 & 4 & 4 & 4 & 2 & 1.23 & 14.4 & 53.8 & 31.1 & 4.8 & 1.0 & & 15.2 & & 1. \\
\hline 59 & 4 & 4 & 3 & 2 & 1.09 & 22.4 & 16.9 & 60.7 & 5.7 & 0.1 & 34. & 3.1 & 3 & \\
\hline 60 & 4 & 4 & 1 & 2 & 1.14 & 18 & 58 & 24 & 6.2 & 0.3 & 32. & 1.9 & 3 & \\
\hline 61 & 4 & 4 & 4 & 2 & 1 & n.m. & n.m. & n.m. & 6.5 & 0.5 & 47.4 & 11.2 & $4 .($ & \\
\hline 62 & 4 & 5 & & 3 & 1.05 & 12 & 41.3 & 46.7 & 4.1 & 0.0 & 28.4 & 5.6 & 2.5 & \\
\hline 63 & 4 & 5 & & 2 & 0.90 & 28 & 25.4 & 46.6 & 4.3 & 0.2 & 38.9 & 0.5 & 3.0 & \\
\hline 64 & 4 & 5 & & 3 & 0.9 & n.m. & n.m. & n.m. & 4.1 & 0.1 & 36.7 & 5.9 & 2.5 & 0. \\
\hline 65 & 5 & 1 & & 3 & 0.83 & 59.6 & 13.6 & 26.8 & 4.4 & 0.5 & 59.1 & 0.9 & $3 . \varepsilon$ & 0. \\
\hline 66 & 5 & 1 & & 3 & 0.90 & 54.1 & 10.6 & 35.3 & 5.1 & 1.4 & 96.8 & 10.0 & 6.7 & 0. \\
\hline 67 & 5 & 2 & 2 & 3 & 0.97 & 34.4 & 27.5 & 38.1 & 5.9 & 0.6 & 52.1 & 0.4 & 4.2 & 0. \\
\hline 68 & 5 & 3 & 8 & 3 & 0.90 & 38 & 25 & 37 & 5.8 & 0.3 & 42.2 & 4.3 & 3.6 & 0.2 \\
\hline 69 & 5 & 4 & 3 & 3 & 0.96 & n.m. & n.m. & n.m. & 5.7 & 0.1 & 50.6 & 7.1 & 4.2 & 0. \\
\hline 70 & 5 & 4 & 9 & 3 & 0.91 & n.m. & n.m. & n.m. & 4.6 & 0.4 & 48.8 & 3.4 & 3.9 & 0. \\
\hline 71 & 5 & 4 & 3 & 3 & 0.96 & n.m. & n.m. & n.m. & 5.4 & 0.7 & 37.2 & 7.0 & 3.3 & 0. \\
\hline 72 & 5 & 5 & & 3 & 0.97 & 63.2 & 8.5 & 28.3 & 4.2 & 0.0 & 48.4 & 0.3 & 3.3 & 0. \\
\hline 73 & 5 & 5 & & 3 & 0.97 & n.m. & n.m. & n.m. & 4.2 & 0.1 & 42.8 & 4.5 & 2.9 & 0. \\
\hline 74 & 5 & 5 & & 3 & 0.97 & n.m. & n.m. & n.m. & 4.2 & 0.1 & 25.8 & 2.2 & 1.8 & 0.1 \\
\hline led & & & & & 1.1 & 19.9 & 43.7 & 36.4 & 5.0 & & 31.6 & & 2.7 & \\
\hline
\end{tabular}


Table 20. Continued

\begin{tabular}{|c|c|c|c|c|c|c|c|c|c|c|c|c|c|}
\hline \multirow[t]{2}{*}{ No. } & \multicolumn{2}{|c|}{$\mathrm{C} / \mathrm{N}$ ratio } & \multicolumn{2}{|c|}{$\mathbf{P ~ m g ~ g ~}^{-1}$} & \multicolumn{2}{|c|}{ CEC mmol kg ${ }^{-1}$} & \multirow{2}{*}{$\begin{array}{c}\text { BS \% } \\
\text { mean }\end{array}$} & \multicolumn{2}{|c|}{ K \% of CEC } & \multicolumn{2}{|c|}{ Ca \% of CEC } & \multicolumn{2}{|c|}{ Mg \% of CEC } \\
\hline & mean & SD & mean & SD & mean & SD & & mean & SD & mean & SD & mean & SD \\
\hline 1 & 10.9 & 0.6 & 0.4 & 0.0 & 132.9 & 66.3 & 98.4 & 2.0 & 0.7 & 64.8 & 0.2 & 30.2 & 2.4 \\
\hline 2 & 11.2 & 0.6 & 0.3 & 0.0 & 154.6 & 64.7 & 98.7 & 2.7 & 0.7 & 78.0 & 4.9 & 16.8 & 4.1 \\
\hline 3 & 12.1 & 0.3 & 0.2 & 0.0 & 59.7 & 9.3 & 99.4 & 4.1 & 1.0 & 65.4 & 14.4 & 17.8 & 3.0 \\
\hline 4 & 10.0 & 0.0 & 0.4 & 0.1 & 106.0 & 15.0 & 97.1 & 4.0 & 1.3 & 62.7 & 5.9 & 24.6 & 1.8 \\
\hline 5 & 11.0 & 0.2 & 0.8 & 0.0 & 197.1 & 14.5 & 99.6 & 2.2 & 0.4 & 76.0 & 1.8 & 20.8 & 1.8 \\
\hline 6 & 11.0 & 0.5 & 0.2 & 0.0 & 94.2 & 16.4 & 84.8 & 4.4 & 1.1 & 78.4 & 1.3 & 14.8 & 2.2 \\
\hline 7 & 12.1 & 0.1 & 0.4 & 0.0 & 48.0 & 5.3 & 97.5 & 4.2 & 0.8 & 66.1 & 3.9 & 16.5 & 1.3 \\
\hline 8 & 12.6 & 0.6 & 0.7 & 0.0 & 136.8 & 11.4 & 85.9 & 2.2 & 0.2 & 73.6 & 1.4 & 23.1 & 1.2 \\
\hline 9 & 11.3 & 0.3 & 0.7 & 0.1 & 138.8 & 28.0 & 98.6 & 2.7 & 0.4 & 69.5 & 2.2 & 26.4 & 1.9 \\
\hline 10 & 13.1 & 0.6 & 0.4 & 0.1 & 58.3 & 23.4 & 95.5 & 4.5 & 1.5 & 70.2 & 11.4 & 15.2 & 1.7 \\
\hline 11 & 16.1 & 3.5 & 0.7 & 0.2 & 109.1 & 45.1 & 76.7 & 1.9 & 1.0 & 72.9 & 4.5 & 19.9 & 0.6 \\
\hline 12 & 11.5 & 0.6 & 0.8 & 0.1 & 319.1 & 55.9 & 33.5 & 2.1 & 0.2 & 71.1 & 5.3 & 25.0 & 4.7 \\
\hline 13 & 10.2 & 0.3 & 1.1 & 0.1 & 167.3 & 30.8 & 99.0 & 5.2 & 0.6 & 68.1 & 5.2 & 25.1 & 4.5 \\
\hline 14 & 10.4 & 0.1 & 0.5 & 0.1 & 157.7 & 14.4 & 98.9 & 3.3 & 1.8 & 83.6 & 3.3 & 12.2 & 3.0 \\
\hline 15 & 11.8 & 0.7 & 0.7 & 0.0 & 96.6 & 12.7 & 98.1 & 4.0 & 0.9 & 81.1 & 1.7 & 12.0 & 0.3 \\
\hline 16 & 12.0 & 0.8 & 0.9 & 0.1 & 122.6 & 25.9 & 88.4 & 3.4 & 0.1 & 71.7 & 12.3 & 22.8 & 12.1 \\
\hline 17 & 13.0 & 0.8 & 1.1 & 0.5 & 316.2 & 115.5 & 97.8 & 3.7 & 0.5 & 83.5 & 2.9 & 12.3 & 2.7 \\
\hline 18 & 11.2 & 1.2 & 0.6 & 0.1 & 105.8 & 18.3 & 91.9 & 3.4 & 0.3 & 78.7 & 2.4 & 16.7 & 2.3 \\
\hline 19 & 11.8 & 0.9 & 0.8 & 0.2 & 131.5 & 13.1 & 87.4 & 6.9 & 3.4 & 76.3 & 5.9 & 15.6 & 2.5 \\
\hline 20 & 10.5 & 0.2 & 0.6 & 0.1 & 81.7 & 18.8 & 99.0 & 2.3 & 0.7 & 76.7 & 2.4 & 19.1 & 2.0 \\
\hline 21 & 11.2 & 0.3 & 0.7 & 0.2 & 181.8 & 44.4 & 99.1 & 2.6 & 0.3 & 74.4 & 5.2 & 22.2 & 5.6 \\
\hline 22 & 9.8 & 0.6 & 0.5 & 0.1 & 186.8 & 69.8 & 96.3 & 2.6 & 0.6 & 59.6 & 2.1 & 36.9 & 1.9 \\
\hline 23 & 10.6 & 0.2 & 0.5 & 0.1 & 116.7 & 18.3 & 98.4 & 5.2 & 0.9 & 48.6 & 24.1 & 17.9 & 2.7 \\
\hline 24 & 10.3 & 0.3 & 0.5 & 0.1 & 176.4 & 25.0 & 99.5 & 3.1 & 0.8 & 49.9 & 9.3 & 42 & 6.6 \\
\hline 25 & 9.9 & 0.3 & 7 & 0.1 & 124.7 & 25.8 & 96.9 & 4.6 & 1.3 & 65. & 9.2 & 29 & 8.9 \\
\hline 26 & 10.9 & 0.5 & 1.0 & 0.2 & 161.8 & 34.0 & 97.7 & 1.3 & 0.4 & 76. & 4.8 & 20.1 & 3.4 \\
\hline 27 & 10.5 & 0.4 & 0.5 & 0.0 & 60.0 & 10.8 & 98.8 & 4.5 & 1.3 & 64. & 5.4 & 17.2 & 1.3 \\
\hline 28 & 10.0 & 0.4 & 0.6 & 0.1 & 79.9 & 4.6 & 99.4 & 2.9 & 0.1 & 71.6 & 2.2 & 18.3 & 1.0 \\
\hline 29 & 14.6 & 0.2 & 0.5 & 0.1 & 103.7 & 15.5 & 43.3 & 2.4 & 0.6 & 80.8 & 4.4 & 11.9 & 2.4 \\
\hline 30 & 11.1 & 0.2 & 0.6 & 0.1 & 108.1 & 11.4 & 97.0 & 4.3 & 1.5 & 66.4 & 0.9 & 23.8 & 0.9 \\
\hline 31 & 13.1 & 0.5 & 0.7 & 0.0 & 90.3 & 11.1 & 94.9 & 6.4 & 3.3 & 55.5 & 1.4 & 35.4 & 2.1 \\
\hline 32 & 10.7 & 0.2 & 0.5 & 0.0 & 74.7 & 9.2 & 99.3 & 6.2 & 1.0 & 70.9 & 4.3 & 17.9 & 1.9 \\
\hline 33 & 11.8 & 0.6 & 0.4 & 0.0 & 86.8 & 30.3 & 99.7 & 7.1 & 0.8 & 66.3 & 5.4 & 20.7 & 1.7 \\
\hline 34 & 10.8 & 0.4 & 0.4 & 0.1 & 118.2 & 43.8 & 98.6 & 5.9 & 1.2 & 46.5 & 12.1 & 33.4 & 2.5 \\
\hline 35 & 10.0 & 0.4 & 0.4 & 0.1 & 141.1 & 54.9 & 98.5 & 3.7 & 0.1 & 77.0 & 4.0 & 14.8 & 1.6 \\
\hline 36 & 10.4 & 0.1 & 0.5 & 0.0 & 109.6 & 8.9 & 99.7 & 6.5 & 0.0 & 36.4 & 14.3 & 42.8 & 0.7 \\
\hline 37 & 11.7 & 0.3 & 0.7 & 0.1 & 247.8 & 85.3 & 97.5 & 2.5 & 0.7 & 86.0 & 3.7 & 10.7 & 2.9 \\
\hline 38 & 11.9 & 0.6 & 0.7 & 0.0 & 134.8 & 26.8 & 98.5 & 1.9 & 0.5 & 73.9 & 8.3 & 20.5 & 5.3 \\
\hline 39 & 13.3 & 0.6 & 0.7 & 0.0 & 219.6 & 52.1 & 87.6 & 1.7 & 0.5 & 89.0 & 4.3 & 8.1 & 2.9 \\
\hline 40 & 12.1 & 0.4 & 0.7 & 0.0 & 271.2 & 15.0 & 93.3 & 3.8 & 1.8 & 82.8 & 4.2 & 12.1 & 2.7 \\
\hline 41 & 13.1 & 0.5 & 0.6 & 0.1 & 207.6 & 24.4 & 95.3 & 2.5 & 0.5 & 82.0 & 0.7 & 14.8 & 1.1 \\
\hline 42 & 13.3 & 0.9 & 1.2 & 0.3 & 218.4 & 17.7 & 95.1 & 3.1 & 1.3 & 74.3 & 6.9 & 21.8 & 5.2 \\
\hline 43 & 12.9 & 0.5 & 0.8 & 0.1 & 254.6 & 75.8 & 95.2 & 2.2 & 0.2 & 86.1 & 3.8 & 11.4 & 3.6 \\
\hline 44 & 12.9 & 0.3 & 0.8 & 0.1 & 228.7 & 36.1 & 94.7 & 1.4 & 0.3 & 77.0 & 2.5 & 20.5 & 2.4 \\
\hline 45 & 14.5 & 0.9 & 0.8 & 0.1 & 115.2 & 7.1 & 93.8 & 4.2 & 1.3 & 78.5 & 2.9 & 14.3 & 0.9 \\
\hline 46 & 12.6 & 0.3 & 1.0 & 0.3 & 159.6 & 23.3 & 96.8 & 2.7 & 0.5 & 68.9 & 3.4 & 27.0 & 2.5 \\
\hline 47 & 11.4 & 0.0 & 1.7 & 0.1 & 282.1 & 9.6 & 99.0 & 1.8 & 0.4 & 81.3 & 1.7 & 15.4 & 1.2 \\
\hline 48 & 12.5 & 0.2 & 0.7 & 0.0 & 150.8 & 11.1 & 97.6 & 3.0 & 0.8 & 78.8 & 0.9 & 17.5 & 0.5 \\
\hline 49 & 11.7 & 0.5 & 0.9 & 0.1 & 136.2 & 11.1 & 99.1 & 2.0 & 0.5 & 70.9 & 2.8 & 23.6 & 1.4 \\
\hline 50 & 10.5 & 0.5 & 0.6 & 0.0 & 180.7 & 51.8 & 99.8 & 2.5 & 0.9 & 86.9 & 0.5 & 9.8 & 1.3 \\
\hline
\end{tabular}




\begin{tabular}{|c|c|c|c|c|c|c|c|c|c|c|c|c|c|}
\hline \multirow[t]{2}{*}{ No. } & \multicolumn{2}{|c|}{$\mathrm{C} / \mathrm{N}$ ratio } & \multicolumn{2}{|c|}{$P$ mg $^{-1}$} & \multicolumn{2}{|c|}{ CEC mmol kg } & \multirow{2}{*}{$\begin{array}{l}\text { BS \% } \\
\text { mean }\end{array}$} & \multicolumn{2}{|c|}{ K \% of CEC } & \multicolumn{4}{|c|}{ Ca \% of CEC Mg \% of CEC } \\
\hline & mean & SD & mean & SD & mean & SD & & mean & SD & mean & SD & mean & SD \\
\hline 51 & 9.8 & 0.1 & 0.8 & 0.1 & 201.0 & 13.0 & 99.3 & 3.6 & 0.5 & 76.8 & 1.2 & 19.2 & 1.0 \\
\hline 52 & 9.6 & 0.5 & 0.4 & 0.0 & 82.5 & 6.9 & 99.8 & 3.7 & 0.2 & 46.7 & 4.2 & 33.4 & 2.8 \\
\hline 53 & 9.2 & 0.1 & 0.5 & 0.1 & 154.6 & 31.6 & 99.0 & 6.0 & 2.1 & 68.4 & 13.4 & 20.1 & 5.1 \\
\hline 54 & 9.4 & 0.3 & 1.5 & 0.0 & 180.1 & 20.9 & 99.2 & 3.4 & 1.0 & 74.0 & 1.7 & 21.5 & 0.9 \\
\hline 55 & 9.0 & 0.1 & 0.6 & 0.1 & 129.4 & 6.4 & 98.6 & 3.1 & 0.5 & 78.9 & 0.6 & 16.2 & 0.3 \\
\hline 56 & 8.3 & 0.0 & 1.2 & 0.2 & 141.8 & 4.6 & 98.1 & 4.6 & 0.2 & 65.6 & 5.7 & 26.4 & 4.3 \\
\hline 57 & 9.5 & 0.4 & 0.7 & 0.0 & 107.2 & 9.5 & 97.0 & 3.8 & 0.0 & 81.4 & 1.4 & 14.0 & 1.2 \\
\hline 58 & 12.5 & 0.7 & 0.4 & 0.2 & 138.4 & 60.7 & 99.3 & 2.9 & 0.4 & 73.4 & 13.7 & 17.7 & 4.8 \\
\hline 59 & 14.4 & 0.2 & 0.9 & 0.1 & 256.9 & 32.1 & 94.8 & 3.0 & 0.9 & 78.9 & 1.8 & 17.9 & 1.0 \\
\hline 60 & 10.9 & 0.1 & 0.7 & 0.0 & 237.8 & 25.2 & 95.4 & 4.1 & 0.9 & 84.6 & 2.6 & 11.2 & 1.8 \\
\hline 61 & 13.6 & 1.2 & 0.7 & 0.1 & 331.8 & 90.0 & 88.9 & 3.0 & 2.4 & 87.6 & 3.3 & 9.1 & 1.7 \\
\hline 62 & 10.0 & 0.4 & 0.2 & 0.0 & 32.8 & 8.3 & 99.3 & 5.0 & 0.4 & 17.9 & 1.1 & 9.2 & 4.0 \\
\hline 63 & 11.0 & 0.7 & 1.3 & 0.0 & 155.9 & 2.7 & 98.9 & 3.5 & 0.5 & 63.7 & 6.1 & 27.3 & 2.1 \\
\hline 64 & 10.8 & 0.3 & 0.8 & 0.2 & 105.7 & 10.9 & 99.3 & 5.9 & 1.2 & 55.5 & 5.0 & 19.9 & 0.6 \\
\hline 65 & 11.5 & 0.0 & 0.7 & 0.1 & 96.7 & 51.0 & 86.7 & 4.5 & 2.0 & 42.5 & 20.4 & 22.2 & 3.5 \\
\hline 66 & 11.9 & 1.0 & 0.8 & 0.1 & 287.7 & 222.3 & 96.8 & 2.1 & 1.7 & 65.9 & 18.5 & 21.5 & 3.2 \\
\hline 67 & 12.0 & 0.3 & 0.7 & 0.1 & 259.6 & 54.2 & 97.7 & 1.4 & 0.4 & 72.4 & 0.9 & 25.4 & 0.4 \\
\hline 68 & 10.2 & 0.7 & 0.6 & 0.2 & 244.6 & 24.7 & 99.4 & 0.5 & 0.1 & 61.5 & 7.4 & 35.8 & 7.2 \\
\hline 69 & 10.3 & 0.7 & 1.1 & 0.1 & 263.0 & 69.7 & 98.9 & 1.0 & 0.3 & 70.6 & 3.8 & 25.7 & 3.4 \\
\hline 70 & 11.8 & 1.3 & 1.3 & 0.1 & 121.9 & 53.0 & 99.6 & 1.8 & 1.0 & 58.4 & 20.0 & 19.6 & 5.7 \\
\hline 71 & 13.6 & 0.2 & 1.1 & 0.1 & 269.7 & 7.2 & 71.9 & 3.6 & 1.3 & 71.6 & 2.1 & 23.3 & 1.5 \\
\hline 72 & 15.0 & 0.4 & 1.2 & 0.1 & 58.1 & 5.3 & 23.7 & 4.3 & 0.2 & 29.0 & 4.9 & 9.0 & 1.6 \\
\hline 73 & 15.0 & 0.2 & 1.0 & 0.0 & 43.5 & 1.9 & 76.0 & 5.0 & 0.3 & 14.2 & 13.4 & 4.0 & 0.7 \\
\hline \multirow[t]{2}{*}{74} & 14.5 & 0.5 & 0.2 & 0.0 & 32.2 & 2.5 & 24.5 & 11.2 & 2.9 & 14.4 & 6.9 & 7.0 & 1.7 \\
\hline & 11.6 & & 0.7 & & 154.0 & & 92.3 & 3.6 & & 68.2 & & 19.9 & \\
\hline
\end{tabular}


Table 20. Continued.

\begin{tabular}{|c|c|c|c|c|c|c|c|c|c|c|}
\hline \multirow[t]{2}{*}{ No. } & \multicolumn{2}{|c|}{ Al \% of CEC } & \multicolumn{2}{|c|}{$\mathrm{K} \mathrm{mg} \mathrm{g}^{-1}$} & \multicolumn{2}{|c|}{ Ca mg g ${ }^{-1}$} & \multicolumn{2}{|c|}{$\mathrm{Mg} \mathrm{mg} \mathrm{g}^{-1}$} & \multicolumn{2}{|c|}{ Al mg g $^{-1}$} \\
\hline & mean & SD & mean & SD & mean & SD & mean & SD & mean & SD \\
\hline 1 & 1.3 & 1.1 & 3.9 & 1.4 & 2.7 & 1.3 & 3.9 & 2.2 & 38.4 & 10.2 \\
\hline 2 & 1.0 & 0.7 & 2.6 & 0.2 & 3.3 & 1.3 & 3.1 & 0.6 & 21.4 & 1.0 \\
\hline 3 & 10.0 & 9.9 & 0.8 & 0.1 & 1.0 & 0.2 & 0.8 & 0.1 & 12.8 & 1.4 \\
\hline 4 & 4.5 & 3.4 & 3.0 & 0.3 & 2.3 & 0.3 & 3.9 & 0.7 & 35.4 & 4.8 \\
\hline 5 & 0.0 & 0.0 & 8.3 & 0.1 & 8.7 & 0.4 & 11.3 & 0.2 & 59.0 & 2.0 \\
\hline 6 & 1.9 & 0.2 & 1.0 & 0.0 & 1.8 & 0.4 & 0.9 & 0.1 & 13.6 & 0.8 \\
\hline 7 & 6.2 & 4.6 & 1.4 & 0.4 & 1.8 & 0.2 & 1.4 & 0.2 & 24.1 & 2.4 \\
\hline 8 & 0.0 & 0.0 & 7.7 & 0.2 & 7.9 & 0.0 & 10.5 & 0.2 & 52.4 & 1.1 \\
\hline 9 & 0.3 & 0.4 & 8.2 & 0.7 & 7.9 & 1.1 & 11.3 & 1.2 & 59.5 & 7.4 \\
\hline 10 & 6.9 & 9.9 & 1.6 & 0.4 & 1.5 & 0.3 & 1.2 & 0.5 & 24.7 & 5.9 \\
\hline 11 & 3.6 & 4.3 & 7.6 & 1.1 & 7.0 & 1.0 & 10.2 & 1.4 & 54.5 & 9.6 \\
\hline 12 & 0.8 & 0.6 & 2.4 & 0.7 & 8.0 & 1.9 & 13.5 & 4.5 & 32.7 & 5.6 \\
\hline 13 & 0.0 & 0.0 & 6.7 & 1.9 & 3.3 & 0.7 & 8.9 & 0.6 & 31.0 & 3.4 \\
\hline 14 & 0.0 & 0.0 & 2.6 & 0.3 & 3.6 & 0.5 & 4.3 & 0.2 & 20.1 & 1.3 \\
\hline 15 & 0.9 & 1.5 & 2.9 & 0.1 & 2.9 & 0.2 & 5.5 & 0.1 & 21.8 & 0.3 \\
\hline 16 & 0.0 & 0.0 & 3.7 & 0.7 & 2.7 & 0.4 & 8.6 & 3.8 & 25.2 & 2.1 \\
\hline 17 & 0.0 & 0.0 & 4.3 & 0.6 & 8.5 & 4.5 & 7.4 & 1.5 & 24.4 & 1.8 \\
\hline 18 & 0.0 & 0.0 & 2.8 & 0.2 & 2.9 & 0.4 & 5.6 & 0.4 & 21.8 & 1.8 \\
\hline 19 & 0.0 & 0.0 & 3.4 & 0.4 & 4.2 & 1.2 & 6.1 & 1.8 & 20.8 & 2.8 \\
\hline 20 & 0.0 & 0.0 & 2.2 & 0.2 & 2.6 & 0.4 & 4.5 & 0.5 & 20.8 & 1.6 \\
\hline 21 & 0.0 & 0.0 & 5.6 & 0.4 & 4.9 & 0.8 & 8.5 & 1.0 & 30.5 & 0.1 \\
\hline 22 & 0.0 & 0.0 & 10.9 & 1.6 & 2.7 & 1.1 & 3.4 & 1.4 & 57.9 & 14.5 \\
\hline 23 & 24.8 & 26.3 & 8.0 & 3.2 & 0.9 & 0.5 & 3.5 & 0.9 & 69.4 & 10.9 \\
\hline 24 & 1.7 & 1.7 & 7.1 & 0.8 & 2.7 & 0.6 & 10.8 & 1.2 & 50.9 & 2.0 \\
\hline 25 & 0.5 & 0.8 & 5.0 & 0.5 & 2.1 & 0.7 & 7.2 & 1.1 & 23.3 & 2.1 \\
\hline 26 & 0.4 & 0.7 & 6.1 & 0.4 & 4.6 & 0.6 & 8.1 & 1.3 & 29.2 & 1.1 \\
\hline 27 & 8.4 & 4.2 & 4.0 & 0.2 & 1.0 & 0.1 & 2.5 & 0.1 & 24.0 & 0.8 \\
\hline 28 & 3.1 & 2.6 & 4.9 & 0.2 & 2.1 & 0.1 & 6.4 & 0.6 & 27.5 & 1.0 \\
\hline 29 & 0.0 & 0.0 & 11.7 & 1.1 & 3.0 & 0.6 & 2.2 & 0.4 & 41.4 & 6.6 \\
\hline 30 & 0.0 & 0.0 & 6.6 & 0.9 & 2.8 & 0.1 & 3.9 & 0.8 & 32.6 & 2.5 \\
\hline 31 & 0.3 & 0.6 & 4.7 & 0.5 & 1.5 & 0.2 & 4.8 & 0.9 & 23.1 & 2.2 \\
\hline 32 & 0.9 & 1.5 & 4.1 & 0.1 & 1.4 & 0.2 & 2.6 & 0.1 & 24.1 & 0.9 \\
\hline 33 & 1.1 & 2.0 & 5.5 & 0.2 & 2.4 & 0.6 & 2.0 & 0.1 & 29.4 & 1.6 \\
\hline 34 & 11.0 & 10.5 & 6.2 & 0.4 & 2.5 & 0.9 & 4.3 & 1.2 & 37.8 & 4.3 \\
\hline 35 & 3.0 & 4.3 & 4.1 & 0.1 & 2.5 & 1.1 & 2.8 & 0.2 & 27.8 & 0.4 \\
\hline 36 & 10.0 & 10.9 & 5.1 & 0.9 & 2.7 & 0.7 & 5.3 & 0.1 & 45.6 & 2.4 \\
\hline 37 & 0.0 & 0.0 & 4.1 & 0.1 & 5.2 & 1.7 & 3.9 & 0.3 & 20.7 & 4.2 \\
\hline 38 & 1.0 & 1.4 & 5.5 & 0.4 & 2.9 & 0.6 & 6.1 & 0.5 & 35.9 & 3.6 \\
\hline 39 & 0.3 & 0.6 & 7.8 & 0.8 & 4.7 & 1.2 & 5.0 & 0.6 & 41.0 & 7.3 \\
\hline 40 & 0.9 & 0.2 & 6.1 & 0.1 & 6.0 & 0.4 & 4.2 & 0.1 & 26.2 & 0.9 \\
\hline 41 & 0.0 & 0.0 & 7.7 & 0.3 & 5.0 & 0.4 & 5.5 & 0.3 & 38.8 & 3.2 \\
\hline 42 & 0.1 & 0.2 & 4.8 & 0.2 & 13.3 & 0.5 & 15.3 & 1.3 & 42.2 & 6.3 \\
\hline 43 & 0.0 & 0.0 & 2.5 & 0.0 & 7.1 & 1.6 & 4.0 & 0.0 & 16.7 & 0.1 \\
\hline 44 & 0.1 & 0.2 & 7.1 & 0.1 & 14.1 & 0.6 & 14.5 & 0.6 & 57.2 & 3.5 \\
\hline 45 & 1.4 & 1.2 & 8.1 & 0.5 & 2.1 & 0.1 & 4.7 & 0.1 & 43.5 & 3.5 \\
\hline 46 & 0.5 & 0.5 & 3.4 & 0.9 & 7.8 & 1.1 & 10.4 & 2.2 & 43.0 & 6.0 \\
\hline 47 & 0.0 & 0.0 & 0.9 & 0.1 & 31.2 & 8.2 & 18.0 & 2.1 & 66.3 & 12.4 \\
\hline 48 & 0.0 & 0.0 & 6.7 & 0.4 & 14.0 & 0.2 & 10.6 & 0.5 & 37.1 & 1.6 \\
\hline 49 & 1.9 & 1.5 & 5.0 & 0.9 & 15.1 & 1.9 & 17.6 & 2.6 & 42.8 & 3.0 \\
\hline 50 & 0.0 & 0.0 & 6.8 & 0.9 & 3.8 & 1.0 & 4.8 & 0.4 & 28.6 & 2.2 \\
\hline
\end{tabular}




\begin{tabular}{|c|c|c|c|c|c|c|c|c|c|c|}
\hline \multirow[t]{2}{*}{ No. } & \multicolumn{2}{|c|}{ Al \% of CEC } & \multicolumn{2}{|c|}{$\mathrm{K} \mathrm{mg} \mathrm{g}^{-1}$} & \multicolumn{2}{|c|}{ Ca $\mathrm{mg} \mathrm{g}^{-1}$} & \multicolumn{2}{|c|}{$\mathrm{Mg} \mathrm{mg} \mathrm{g}^{-1}$} & \multicolumn{2}{|c|}{$\mathrm{Al} \mathrm{mg} \mathrm{g}^{-1}$} \\
\hline & mean & SD & mean & SD & mean & SD & mean & SD & mean & SD \\
\hline 51 & 0.0 & 0.0 & 6.5 & 0.0 & 13.6 & 1.0 & 10.7 & 0.7 & 39.5 & 2.1 \\
\hline 52 & 12.7 & 3.3 & 1.0 & 0.3 & 4.5 & 0.2 & 4.7 & 1.4 & 40.8 & 1.8 \\
\hline 53 & 3.3 & 5.8 & 4.3 & 0.9 & 8.4 & 1.7 & 14.4 & 1.5 & 41.6 & 1.4 \\
\hline 54 & 0.0 & 0.0 & 6.0 & 0.1 & 13.4 & 0.7 & 15.9 & 0.8 & 37.4 & 2.6 \\
\hline 55 & 0.6 & 0.6 & 6.9 & 0.3 & 3.2 & 0.2 & 5.4 & 0.3 & 37.1 & 1.7 \\
\hline 56 & 1.9 & 1.5 & 5.4 & 1.7 & 10.6 & 2.0 & 14.1 & 2.7 & 45.4 & 6.0 \\
\hline 57 & 0.0 & 0.0 & 6.7 & 0.7 & 2.4 & 0.1 & 5.4 & 0.6 & 28.8 & 1.3 \\
\hline 58 & 4.3 & 7.4 & 7.1 & 0.9 & 3.1 & 1.3 & 5.1 & 0.8 & 37.0 & 4.2 \\
\hline 59 & 0.0 & 0.0 & 7.4 & 0.3 & 16.9 & 0.6 & 15.0 & 0.4 & 54.0 & 2.3 \\
\hline 60 & 0.0 & 0.0 & 6.6 & 0.4 & 5.3 & 0.6 & 4.9 & 0.2 & 29.8 & 1.9 \\
\hline 61 & 0.0 & 0.0 & 7.3 & 1.0 & 7.3 & 2.6 & 4.6 & 0.4 & 38.9 & 6.5 \\
\hline 62 & 62.2 & 4.0 & 0.3 & 0.0 & 1.1 & 0.3 & 0.6 & 0.2 & 28.1 & 4.4 \\
\hline 63 & 3.8 & 3.8 & 5.2 & 1.3 & 10.2 & 0.5 & 14.2 & 0.1 & 41.5 & 9.2 \\
\hline 64 & 17.5 & 6.8 & 3.8 & 0.3 & 6.2 & 0.1 & 9.9 & 1.4 & 36.3 & 9.2 \\
\hline 65 & 19.0 & 20.4 & 0.3 & 0.0 & 2.8 & 3.4 & 1.6 & 1.3 & 129.7 & 7.2 \\
\hline 66 & 7.8 & 10.6 & 0.8 & 0.8 & 5.4 & 5.5 & 1.2 & 0.6 & 104.4 & 16.6 \\
\hline 67 & 0.0 & 0.0 & 0.3 & 0.1 & 12.5 & 4.8 & 6.7 & 3.8 & 73.7 & 4.4 \\
\hline 68 & 0.4 & 0.1 & 0.3 & 0.1 & 9.3 & 1.7 & 15.1 & 4.0 & 104.6 & 2.3 \\
\hline 69 & 0.0 & 0.0 & 0.3 & 0.0 & 9.4 & 4.3 & 3.6 & 1.7 & 91.2 & 5.4 \\
\hline 70 & 10.1 & 17.0 & 0.2 & 0.2 & 3.0 & 1.6 & 1.8 & 0.4 & 104.5 & 1.3 \\
\hline 71 & 0.1 & 0.2 & 5.1 & 0.1 & 19.4 & 1.4 & 20.6 & 0.7 & 61.5 & 9.7 \\
\hline 72 & 43.5 & 6.1 & 0.2 & 0.0 & 0.9 & 0.1 & 1.0 & 0.1 & 115.7 & 2.2 \\
\hline 73 & 69.4 & 13.5 & 0.0 & 0.0 & 0.3 & 0.1 & 0.5 & 0.0 & 108.6 & 1.7 \\
\hline 74 & 62.7 & 7.0 & 0.3 & 0.1 & 0.6 & 0.2 & 0.4 & 0.1 & 17.3 & 5.5 \\
\hline & 5.8 & & 4.5 & & 5.8 & & 6.8 & & 42.9 & \\
\hline
\end{tabular}


Table 21. Soil survey data, 30-40 cm depth.

\begin{tabular}{|c|c|c|c|c|c|c|c|c|c|c|c|c|c|}
\hline \multirow[t]{2}{*}{ No. } & \multirow[t]{2}{*}{ Vill. } & \multirow[t]{2}{*}{ LUS } & \multirow{2}{*}{$\begin{array}{c}\text { Age } \\
\mathbf{y}\end{array}$} & \multirow{2}{*}{$\begin{array}{l}\text { Soil } \\
\text { type }\end{array}$} & \multirow{2}{*}{$\begin{array}{l}\text { TRD } \\
\mathrm{g} \mathrm{cm}^{-3}\end{array}$} & \multicolumn{2}{|c|}{ pH KCl } & \multicolumn{2}{|c|}{$\mathrm{C} \mathrm{mg} \mathrm{g}^{-1}$} & \multicolumn{2}{|c|}{$\mathbf{N} \mathbf{m g ~ g}^{-1}$} & \multicolumn{2}{|c|}{$\mathrm{C} / \mathrm{N}$ ratio } \\
\hline & & & & & & mean & SD & mean & SD & mean & SD & mean & SD \\
\hline 1 & 1 & 1 & & 1 & 1.51 & 3.5 & 0.0 & 5.8 & 0.7 & 0.6 & 0.1 & 9.4 & $\overline{0.4}$ \\
\hline 2 & 1 & 1 & & 1 & 1.23 & 4.2 & 0.2 & 4.4 & 0.5 & 0.4 & 0.1 & 9.4 & 0.2 \\
\hline 3 & 1 & 2 & & 1 & 1.14 & 4.3 & 0.0 & 9.7 & 1.5 & 0.8 & 0.1 & 9.5 & 0.5 \\
\hline 4 & 1 & 2 & 5 & 1 & 1.32 & 3.7 & 0.5 & 8.8 & 2.2 & 0.8 & 0.2 & 9.9 & 0.5 \\
\hline 5 & 1 & 3 & 10 & 2 & 1.24 & 4.1 & 0.1 & 6.4 & 1.3 & 0.6 & 0.1 & 7.8 & 2.0 \\
\hline 6 & 1 & 4 & 2 & 1 & 1.37 & 4.3 & 0.3 & 7.7 & 2.3 & 0.7 & 0.1 & 10.4 & 0.3 \\
\hline 7 & 1 & 4 & 2 & 1 & 1.38 & 4.0 & 0.1 & 6.6 & 0.4 & 0.7 & 0.0 & 10.6 & 1.1 \\
\hline 8 & 1 & 4 & 10 & 2 & 1.22 & 4.2 & 0.1 & 5.5 & 0.4 & 0.6 & 0.0 & 11.5 & 0.1 \\
\hline 9 & 1 & 4 & 1 & 2 & 1.37 & 4.2 & 0.0 & 4.3 & 2.5 & 0.4 & 0.4 & 9.4 & 0.6 \\
\hline 10 & 1 & 4 & 2 & 1 & 1.34 & 3.8 & 0.1 & 7.9 & 1.2 & 0.6 & 0.1 & 11.6 & 0.8 \\
\hline 11 & 1 & 5 & & 2 & 1.28 & 4.2 & 0.1 & 10.4 & 1.5 & 1.2 & 0.2 & 12.6 & 2.0 \\
\hline 12 & 2 & 1 & & 1 & 1.40 & 4.9 & 0.1 & 15.9 & 5.2 & 1.7 & 0.6 & 10.4 & 0.3 \\
\hline 13 & 2 & 1 & & 1 & 1.17 & 3.7 & 0.1 & 10.4 & 1.2 & 1.2 & 0.1 & 9.5 & 0.3 \\
\hline 14 & 2 & 2 & 2 & 1 & 1.43 & 4.6 & 0.6 & 8.0 & 0.8 & 1.0 & 0.1 & 10.1 & 0.8 \\
\hline 15 & 2 & 3 & 7 & 1 & 1.40 & 4.4 & 0.1 & 7.0 & 0.6 & 0.6 & 0.1 & 11.0 & 0.5 \\
\hline 16 & 2 & 3 & 4 & 2 & 1.29 & 4.1 & 0.4 & 8.7 & 0.5 & 1.1 & 0.1 & 12.4 & 0.7 \\
\hline 17 & 2 & 4 & 4 & 1 & 1.39 & 4.4 & 0.8 & 7.9 & 2.3 & 0.9 & 0.2 & 11.1 & 1.9 \\
\hline 18 & 2 & 4 & 7 & 1 & 1.48 & 4.3 & 0.3 & 5.3 & 1.1 & 0.5 & 0.1 & 10.3 & 0.4 \\
\hline 19 & 2 & 4 & 1 & 1 & 1.39 & 4.3 & 0.1 & 7.9 & 3.1 & 0.9 & 0.4 & 9.7 & 0.4 \\
\hline 20 & 2 & 4 & 7 & 1 & 1.53 & 4.7 & 0.1 & 6.5 & 1.9 & 0.7 & 0.2 & 9.7 & 0.1 \\
\hline 21 & 3 & 1 & & 1 & 1.31 & 3.8 & 0.5 & 7.5 & 0.7 & 0.9 & 0.1 & 9.9 & 0.8 \\
\hline 22 & 3 & 1 & & 1 & 1.23 & 4.0 & 0.5 & 10.6 & 2.7 & 1.1 & 0.3 & 9.0 & 0.0 \\
\hline 23 & 3 & 1 & & 1 & 1.07 & 4.0 & 0.2 & 23.1 & 8.6 & 1.8 & 0.5 & 10.1 & 0.2 \\
\hline 24 & 3 & 2 & 2 & 1 & 1.31 & 3.6 & 0.3 & 6.7 & 1.6 & 0.6 & 0.1 & 9.9 & 0.7 \\
\hline 25 & 3 & 2 & 3 & 1 & 1.26 & 4.5 & 0.6 & 14.7 & 8.7 & 1.3 & 0.6 & 9.2 & 0.2 \\
\hline 26 & 3 & 3 & 7 & 1 & 1.41 & 4.4 & 0.2 & 8.4 & 1.9 & 0.9 & 0.1 & 9.5 & 0.2 \\
\hline 27 & 3 & 3 & 2 & 1 & 1.44 & 3.7 & 0.1 & 6.2 & 1.0 & 0.5 & 0.1 & 9.4 & 0.1 \\
\hline 28 & 3 & 3 & 3 & 1 & 1.40 & 3.8 & 0.0 & 6.5 & 1.9 & 0.7 & 0.2 & 9.6 & 0.5 \\
\hline 29 & 3 & 3 & 4 & 1 & 1.41 & 4.6 & 0.5 & 6.8 & 0.7 & 0.6 & 0.1 & 12.6 & 0.3 \\
\hline 30 & 3 & 3 & 8 & 1 & 1.47 & 4.1 & 0.2 & 7.1 & 1.7 & 0.6 & 0.1 & 10.2 & 0.3 \\
\hline 31 & 3 & 4 & 3 & 1 & 1.50 & 3.9 & 0.2 & 6.8 & 2.9 & 0.6 & 0.3 & 10.4 & 1.8 \\
\hline 32 & 3 & 4 & 3 & 1 & 1.38 & 3.6 & 0.1 & 6.2 & 2.1 & 0.5 & 0.2 & 11.2 & 0.9 \\
\hline 33 & 3 & 4 & 3 & 1 & 1.37 & 3.7 & 0.1 & 5.9 & 0.7 & 0.5 & 0.1 & 10.8 & 0.1 \\
\hline 34 & 3 & 4 & 1 & 1 & 1.26 & 3.6 & 0.1 & 8.1 & 1.7 & 0.7 & 0.1 & 10.0 & 0.4 \\
\hline 35 & 3 & 4 & 1 & 1 & 1.22 & 3.4 & 0.1 & 4.8 & 2.2 & 0.4 & 0.2 & 8.7 & 0.1 \\
\hline 36 & 3 & 5 & 1 & 1 & 1.19 & 3.5 & 0.0 & 9.8 & 2.6 & 0.9 & 0.2 & 9.0 & 0.1 \\
\hline 37 & 4 & 1 & & 2 & 1.38 & 5.0 & 0.6 & 8.8 & 0.9 & 0.9 & 0.1 & 11.4 & 0.0 \\
\hline 38 & 4 & 1 & & 2 & 1.31 & 3.6 & 0.1 & 6.1 & 0.9 & 0.7 & 0.1 & 9.2 & 0.7 \\
\hline 39 & 4 & 1 & & 2 & 1.33 & 4.3 & 0.7 & 8.9 & 2.7 & 0.9 & 0.3 & 11.5 & 0.9 \\
\hline 40 & 4 & 2 & 4 & 2 & 1.66 & 4.6 & 0.5 & 11.6 & 2.9 & 1.2 & 0.3 & 9.9 & 0.4 \\
\hline 41 & 4 & 2 & & 2 & 1.50 & 3.8 & 0.2 & 5.0 & 0.6 & 0.5 & 0.1 & 11.4 & 0.4 \\
\hline 42 & 4 & 2 & & 3 & 1.26 & 3.9 & 0.1 & 7.8 & 1.4 & 0.8 & 0.1 & 10.7 & 0.3 \\
\hline 43 & 4 & 2 & 2 & 1 & 1.55 & 5.1 & 0.1 & 7.3 & 1.8 & 0.7 & 0.2 & 10.8 & 0.6 \\
\hline 44 & 4 & 2 & 10 & 2 & 1.28 & 3.8 & 0.0 & 6.9 & 0.2 & 0.7 & 0.1 & 10.9 & 0.6 \\
\hline 45 & 4 & 3 & 3 & 2 & 1.39 & 4.6 & 0.2 & 9.2 & 1.3 & 0.9 & 0.2 & 14.1 & 0.8 \\
\hline 46 & 4 & 3 & 6 & 3 & 1.34 & 3.9 & 0.3 & 9.5 & 1.9 & 0.9 & 0.1 & 13.1 & 0.5 \\
\hline 47 & 4 & 3 & 4 & 2 & 1.38 & 4.9 & 0.1 & 11.5 & 2.7 & 1.2 & 0.3 & 10.8 & 0.2 \\
\hline 48 & 4 & 3 & 4 & 2 & 1.15 & 4.4 & 0.1 & 6.2 & 0.9 & 0.7 & 0.1 & 11.2 & 0.4 \\
\hline 49 & 4 & 3 & 3 & 2 & 1.18 & 4.2 & 0.2 & 9.0 & 2.1 & 0.9 & 0.3 & 9.3 & 0.4 \\
\hline
\end{tabular}




\begin{tabular}{|c|c|c|c|c|c|c|c|c|c|c|c|c|c|}
\hline \multirow[t]{2}{*}{ No. } & \multirow[t]{2}{*}{ Vill. } & \multirow[t]{2}{*}{ LUS } & \multirow{2}{*}{$\begin{array}{c}\text { Age } \\
\text { y }\end{array}$} & \multirow{2}{*}{$\begin{array}{l}\text { Soil } \\
\text { type }\end{array}$} & \multirow{2}{*}{$\begin{array}{l}\text { TRD } \\
\mathrm{g} \mathrm{cm}^{-3}\end{array}$} & \multirow{2}{*}{$\begin{array}{r}\mathbf{p H} \\
\text { mean }\end{array}$} & \multirow{2}{*}{$\begin{array}{r}\text { KCl } \\
\text { SD }\end{array}$} & \multicolumn{2}{|c|}{$\mathrm{C} \mathrm{mg} \mathrm{g}^{-1}$} & \multicolumn{2}{|c|}{$\mathrm{N} \mathrm{mg} \mathrm{g}^{-1}$} & \multicolumn{2}{|c|}{$\mathrm{C} / \mathrm{N}$ ratio } \\
\hline & & & & & & & & mean & SD & mean & SD & mean & SD \\
\hline 50 & 4 & 3 & 6 & 2 & 1.39 & 4.8 & 0.3 & 8.6 & 1.0 & 1.0 & 0.1 & 9.3 & 0.1 \\
\hline 51 & 4 & 4 & 4 & 2 & 1.14 & 4.3 & 0.1 & 9.6 & 1.3 & 1.3 & 0.2 & 9.4 & 0.4 \\
\hline 52 & 4 & 4 & 1 & 3 & 1.32 & 4.0 & 0.2 & 12.7 & 1.0 & 1.2 & 0.1 & 9.4 & 0.2 \\
\hline 53 & 4 & 4 & 3 & 3 & 1.47 & 3.9 & 0.2 & 7.6 & 2.5 & 0.6 & 0.2 & 8.4 & 0.2 \\
\hline 54 & 4 & 4 & 2 & 3 & 1.32 & 4.0 & 0.2 & 10.9 & 2.1 & 1.2 & 0.2 & 8.4 & 0.5 \\
\hline 55 & 4 & 4 & 4 & 2 & 1.49 & 3.7 & 0.1 & 5.9 & 1.6 & 0.6 & 0.2 & 8.9 & 0.2 \\
\hline 56 & 4 & 4 & 1 & 2 & 1.09 & 4.3 & 0.0 & 7.8 & 1.1 & 0.8 & 0.1 & 8.0 & 0.1 \\
\hline 57 & 4 & 4 & 1 & 2 & 1.39 & 4.6 & 0.1 & 6.5 & 1.4 & 0.3 & 0.3 & 10.1 & 1.3 \\
\hline 58 & 4 & 4 & 4 & 2 & 1.48 & 3.8 & 0.2 & 4.4 & 0.8 & 0.3 & 0.1 & 9.9 & 0.2 \\
\hline 59 & 4 & 4 & 3 & 2 & 1.12 & 4.6 & 0.2 & 6.7 & 1.8 & 0.7 & 0.2 & 16.3 & 2.0 \\
\hline 60 & 4 & 4 & 1 & 2 & 1.58 & 4.3 & 0.2 & 7.6 & 0.3 & 0.8 & 0.0 & 11.0 & 0.2 \\
\hline 61 & 4 & 4 & 4 & 2 & 1.34 & 5.8 & 0.6 & 14.9 & 7.4 & 1.4 & 0.7 & 11.5 & 1.1 \\
\hline 62 & 4 & 5 & & 3 & 1.44 & 3.9 & 0.0 & 7.6 & 0.7 & 0.7 & 0.1 & 8.5 & 0.2 \\
\hline 63 & 4 & 5 & & 2 & 1.10 & 4.1 & 0.1 & 9.9 & 2.1 & 1.0 & 0.1 & 10.8 & 1.7 \\
\hline 64 & 4 & 5 & & 3 & 1.1 & 4.2 & 0.1 & 13.5 & 2.8 & 1.0 & 0.3 & 9.9 & 0.5 \\
\hline 65 & 5 & 1 & & 3 & 1.07 & 4.1 & 0.2 & 17.2 & 3.6 & 1.4 & 0.5 & 10.6 & 0.6 \\
\hline 66 & 5 & 1 & & 3 & 1.18 & 4.1 & 0.3 & 15.6 & 9.8 & 1.0 & 0.7 & 11.3 & 0.3 \\
\hline 67 & 5 & 2 & 2 & 3 & 1.13 & 4.7 & 0.5 & 18.8 & 10.1 & 1.9 & 1.1 & 10.5 & 0.1 \\
\hline 68 & 5 & 3 & 8 & 3 & 1.15 & 5.1 & 0.1 & 13.3 & 2.9 & 1.2 & 0.2 & 8.7 & 0.5 \\
\hline 69 & 5 & 4 & 3 & 3 & 1.28 & 4.8 & 0.4 & 10.8 & 1.5 & 1.0 & 0.1 & 9.8 & 0.3 \\
\hline 70 & 5 & 4 & 9 & 3 & 1.23 & 4.5 & 0.2 & 18.4 & 2.2 & 1.6 & 0.2 & 10.3 & 1.0 \\
\hline 71 & 5 & 4 & 3 & 3 & 1.14 & 4.4 & 0.1 & 7.9 & 3.7 & 0.7 & 0.6 & 12.8 & 1.1 \\
\hline 72 & 5 & 5 & & 3 & 1.31 & 4.4 & 0.2 & 14.5 & 0.9 & 1.2 & 0.1 & 14.6 & 0.4 \\
\hline 73 & 5 & 5 & & 3 & 1.31 & 4.4 & 0.0 & 24.8 & 1.8 & 1.7 & 0.2 & 13.1 & 0.8 \\
\hline 74 & 5 & 5 & & 3 & 1.31 & 4.2 & 0.0 & 7.8 & 1.8 & 0.7 & 0.0 & 11.6 & 2.4 \\
\hline & & & & & & 4.2 & & 9.3 & & 0.9 & & 10.4 & \\
\hline
\end{tabular}


Table 21. Continued.

\begin{tabular}{|c|c|c|c|c|c|c|c|c|c|c|c|c|c|}
\hline \multirow[t]{2}{*}{ No. } & \multicolumn{2}{|c|}{$P$ mg g $^{-1}$} & \multicolumn{2}{|c|}{ CEC mmol kg-1 } & \multirow{2}{*}{$\begin{array}{l}\text { BS \% } \\
\text { mean }\end{array}$} & \multicolumn{2}{|c|}{ K \% of CEC } & \multicolumn{2}{|c|}{ Ca \% of CEC } & \multicolumn{4}{|c|}{ Mg \% of CEC Al \% of CEC } \\
\hline & mean & SD & mean & SD & & mean & SD & mean & SD & mean & SD & mean & SD \\
\hline 1 & 0.3 & 0.0 & 101.7 & 52.6 & 72.0 & 1.4 & 0.0 & 30.9 & 4.6 & 39.2 & 11.0 & 23.7 & 14.0 \\
\hline 2 & 0.1 & 0.0 & 23.9 & 3.4 & 66.2 & 3.3 & 0.7 & 43.2 & 13.9 & 19.1 & 5.7 & 31.0 & 17.6 \\
\hline 3 & 0.1 & 0.0 & 19.3 & 0.4 & 28.2 & 3.6 & 1.5 & 17.5 & 12.2 & 6.4 & 2.0 & 68.6 & 13.9 \\
\hline 4 & 0.3 & 0.1 & 84.8 & 18.0 & 72.1 & 1.1 & 0.0 & 39.5 & 22.7 & 29.9 & 2.7 & 23.1 & 16.7 \\
\hline 5 & 0.5 & 0.0 & 88.3 & 7.5 & 94.1 & 1.8 & 0.6 & 64.4 & 0.9 & 27.7 & 1.2 & 3.9 & 0.9 \\
\hline 6 & 0.2 & 0.0 & 24.0 & 1.7 & 58.9 & 6.1 & 5.1 & 42.4 & 10.9 & 9.8 & 5.9 & 38.9 & 14.4 \\
\hline 7 & 0.3 & 0.1 & 27.3 & 3.9 & 74.8 & 1.8 & 0.2 & 51.8 & 7.5 & 20.2 & 1.0 & 19.1 & 6.5 \\
\hline 8 & 0.5 & 0.0 & 89.7 & 8.5 & 97.4 & 1.3 & 0.3 & 67.8 & 0.5 & 27.9 & 1.8 & 1.3 & 1.1 \\
\hline 9 & 0.4 & 0.0 & 59.6 & 21.0 & 94.1 & 1.8 & 0.8 & 64.8 & 3.5 & 26.9 & 0.8 & 4.4 & 1.7 \\
\hline 10 & 0.2 & 0.0 & 29.2 & 0.8 & 29.5 & 2.8 & 0.6 & 21.4 & 0.5 & 5.0 & 1.1 & 65.5 & 2.4 \\
\hline 11 & 0.5 & 0.0 & 116.8 & 9.0 & 94.2 & 0.8 & 0.1 & 75.1 & 1.5 & 17.7 & 2.2 & 4.7 & 0.4 \\
\hline 12 & 0.5 & 0.0 & 92.2 & 19.4 & 95.6 & 2.7 & 1.3 & 57.1 & 9.8 & 35.5 & 9.6 & 1.7 & 0.7 \\
\hline 13 & 1.2 & 0.2 & 92.9 & 5.4 & 59.7 & 4.9 & 1.9 & 28.4 & 4.3 & 26.2 & 3.4 & 36.1 & 7.1 \\
\hline 14 & 0.5 & 0.0 & 72.6 & 26.4 & 96.5 & 1.7 & 0.8 & 80.9 & 10.7 & 13.6 & 7.4 & 1.8 & 1.6 \\
\hline 15 & 0.7 & 0.0 & 78.8 & 1.4 & 96.3 & 2.5 & 0.4 & 81.4 & 1.6 & 11.8 & 1.3 & 2.5 & 2.6 \\
\hline 16 & 0.9 & 0.3 & 104.8 & 48.5 & 83.5 & 3.2 & 1.0 & 58.3 & 29.7 & 21.6 & 10.3 & 14.9 & 18.3 \\
\hline 17 & 0.6 & 0.2 & 105.2 & 10.7 & 90.5 & 3.8 & 1.7 & 64.2 & 9.4 & 22.0 & 3.9 & 7.0 & 11.4 \\
\hline 18 & 0.4 & 0.1 & 73.4 & 9.9 & 95.0 & 2.2 & 0.6 & 69.7 & 7.9 & 22.4 & 3.6 & 3.6 & 3.9 \\
\hline 19 & 0.7 & 0.2 & 67.7 & 3.5 & 88.7 & 4.0 & 1.4 & 71.5 & 12.2 & 12.6 & 1.3 & 9.7 & 13.0 \\
\hline 20 & 0.5 & 0.2 & 72.5 & 13.0 & 99.1 & 1.2 & 0.2 & 73.9 & 4.3 & 23.3 & 4.3 & 0.0 & 0.0 \\
\hline 21 & 0.7 & 0.2 & 126.4 & 26.2 & 90.8 & 1.6 & 0.4 & 67.2 & 3.3 & 21.6 & 8.0 & 6.6 & 6.0 \\
\hline 22 & 0.4 & 0.1 & 101.8 & 41.9 & 82.2 & 2.2 & 1.3 & 29.5 & 3.4 & 50.3 & 17.2 & 14.5 & 14.7 \\
\hline 23 & 0.4 & 0.0 & 58.8 & 9.6 & 33.8 & 4.0 & 1.1 & 20.5 & 18.7 & 9.1 & 3.5 & 62.7 & 22.9 \\
\hline 24 & 0.3 & 0.1 & 140.3 & 5.7 & 72.3 & 1.4 & 0.5 & 25.8 & 13.1 & 44.6 & 3.3 & 23.1 & 14.4 \\
\hline 25 & 0.6 & 0.1 & 106.5 & 38.7 & 94.8 & 2.8 & 0.5 & 63.6 & 6.7 & 28.2 & 6.8 & 3.9 & 4.3 \\
\hline 26 & 0.9 & 0.2 & 110.1 & 3.4 & 96.3 & 1.8 & 0.5 & 69.9 & 5.5 & 24.1 & 3.6 & 2.7 & 2.0 \\
\hline 27 & 0.4 & 0.1 & 41.4 & 0.9 & 42.3 & 4.0 & 1.1 & 28.0 & 1.3 & 9.5 & 0.7 & 51.5 & 0.4 \\
\hline 28 & 0.5 & 0.1 & 63.7 & 2.2 & 78.8 & 2.4 & 0.4 & 56.5 & 5.3 & 19.3 & 2.3 & 17.3 & 3.4 \\
\hline 29 & 0.4 & 0.1 & 38.1 & 6.3 & 85.4 & 4.3 & 1.5 & 67.8 & 12.5 & 13.2 & 3.1 & 4.7 & 4.0 \\
\hline 30 & 0.5 & 0.1 & 62.1 & 7.6 & 86.0 & 3.6 & 0.8 & 53.6 & 4.5 & 28.6 & 3.2 & 7.0 & 3.5 \\
\hline 31 & 0.5 & 0.1 & 71.8 & 1.1 & 85.6 & 3.6 & 0.9 & 40.5 & 7.7 & 41.2 & 2.1 & 10.8 & 5.8 \\
\hline 32 & 0.3 & 0.0 & 38. & 4.5 & 48.6 & 5.4 & 1.4 & 32.3 & 14.5 & 10.3 & 2.7 & 44.9 & 17.8 \\
\hline 33 & 0.3 & 0.0 & 40.6 & 4.1 & 59.6 & 6.0 & 3.3 & 39.1 & 4.3 & 14.2 & 5.9 & 33.8 & 7.2 \\
\hline 34 & 0.2 & 0.0 & 90.5 & 9.1 & 36.3 & 1.8 & 0.3 & 8.3 & 4.5 & 25.5 & 8.8 & 59.1 & 13.8 \\
\hline 35 & 0.2 & 0.0 & 67.0 & 1.2 & 20.0 & 1.0 & 0.3 & 11.2 & 0.4 & 6.7 & 4.1 & 75.4 & 3.7 \\
\hline 36 & 0.3 & 0.1 & 99.4 & 5.7 & 43.5 & 2.2 & 0.6 & 14.2 & 4.2 & 26.2 & 2.9 & 50.8 & 0.5 \\
\hline 37 & 0.5 & 0.1 & 6 & 14.7 & 94.7 & 4.3 & 1.2 & 82.4 & 8.8 & 7.5 & 0.6 & 3.8 & 6.8 \\
\hline 38 & 0.4 & 0.0 & 64.4 & 6.4 & 42.4 & 1.7 & 0.9 & 29.5 & 9.9 & 9.9 & 2.1 & 53.1 & 9.7 \\
\hline 39 & 0.5 & 0.1 & 74.5 & 12.6 & 88.7 & 2.5 & 0.5 & 72.4 & 13.7 & 13.5 & 6.8 & 8.8 & 11.6 \\
\hline 40 & 0.5 & 0.1 & 101.5 & 26.9 & 96.9 & 2.7 & 0.6 & 82.4 & 4.4 & 11.5 & 1.0 & 1.8 & 3.1 \\
\hline 41 & 0.2 & 0.0 & 96.1 & 4.7 & 87.7 & 2.6 & 0.4 & 59.9 & 7.3 & 24.4 & 2.0 & 10.0 & 4.6 \\
\hline 42 & 0.7 & 0.0 & 120.3 & 4.4 & 91.9 & 1.2 & 0.2 & 64.0 & 8.4 & 25.3 & 3.3 & 6.5 & 4.4 \\
\hline 43 & 0.4 & 0.0 & & 6.9 & 99.5 & 4.2 & 0.7 & 79.9 & 1.4 & 14.5 & 1.6 & 0.0 & 0.0 \\
\hline 44 & 0.5 & 0.0 & 79.5 & 3.2 & 85.4 & 1.1 & 0.2 & 61.9 & 1.5 & 20.8 & 0.9 & 11.0 & 0.7 \\
\hline 45 & 0.5 & 0.1 & 80.8 & 2.9 & 95.1 & 2.6 & 0.3 & 80.4 & 2.5 & 11.9 & 1.7 & 3.7 & 0.6 \\
\hline 46 & 0.8 & 0.5 & 109.5 & 12.8 & 89.7 & 1.3 & 0.4 & 57.2 & 5.9 & 30.3 & 1.0 & 8.4 & 6.0 \\
\hline 47 & 1.4 & 0.1 & 159.0 & 13.6 & 98.1 & 1.6 & 0.8 & 75.3 & 3.8 & 20.8 & 3.4 & 0.0 & 0.0 \\
\hline 48 & 0.5 & 0.1 & 77.1 & 15.1 & 97.2 & 3.4 & 2.0 & 72.0 & 2.6 & 21.4 & 1.3 & 1.8 & 0.9 \\
\hline 49 & 0.8 & 0.0 & 146.2 & 18.0 & 96.7 & 0.9 & 0.2 & 70.6 & 2.7 & 24.3 & 1.8 & 2.4 & 1.9 \\
\hline
\end{tabular}




\begin{tabular}{|c|c|c|c|c|c|c|c|c|c|c|c|c|c|}
\hline \multirow[t]{2}{*}{ No. } & \multicolumn{2}{|c|}{$\mathbf{P ~ m g ~ g}^{-1}$} & \multicolumn{2}{|c|}{ CEC mmol kg } & \multirow{2}{*}{$\begin{array}{c}\text { BS \% } \\
\text { mean }\end{array}$} & \multicolumn{2}{|c|}{ K \% of CEC } & \multicolumn{2}{|c|}{ Ca \% of CEC } & \multicolumn{2}{|c|}{ Mg \% of CEC } & \multicolumn{2}{|c|}{ Al \% of CEC } \\
\hline & mean & SD & mean & SD & & mean & SD & mean & SD & mean & SD & mean & SD \\
\hline 50 & 0.4 & 0.1 & 60.1 & 22.1 & 97.5 & 1.3 & 0.1 & 85.4 & 3.0 & 10.2 & 2.6 & 1.7 & 1.5 \\
\hline 51 & 0.6 & 0.0 & 103.1 & 2.7 & 96.4 & 2.5 & 0.6 & 70.7 & 1.1 & 22.9 & 1.3 & 2.4 & 1.6 \\
\hline 52 & 0.2 & 0.0 & 91.5 & 11.0 & 85.2 & 1.2 & 0.1 & 46.9 & 0.9 & 36.4 & 8.4 & 12.6 & 8.0 \\
\hline 53 & 0.3 & 0.2 & 84.2 & 23.7 & 81.5 & 1.6 & 0.2 & 60.5 & 9.1 & 18.0 & 1.7 & 16.4 & 10.9 \\
\hline 54 & 1.0 & 0.1 & 151.6 & 27.1 & 93.9 & 1.2 & 0.1 & 72.3 & 3.4 & 19.6 & 0.7 & 4.9 & 3.5 \\
\hline 55 & 0.3 & 0.0 & 63.7 & 6.7 & 49.2 & 2.2 & 0.2 & 33.9 & 4.0 & 12.3 & 0.6 & 47.6 & 4.9 \\
\hline 56 & 0.7 & 0.0 & 124.9 & 2.0 & 95.9 & 1.0 & 0.1 & 69.0 & 2.3 & 24.5 & 3.3 & 3.3 & 1.1 \\
\hline 57 & 0.5 & 0.0 & 49.8 & 5.3 & 93.0 & 2.7 & 0.5 & 78.7 & 8.1 & 11.2 & 2.6 & 6.2 & 5.2 \\
\hline 58 & 0.2 & 0.0 & 84.1 & 18.2 & 87.8 & 2.0 & 0.6 & 60.6 & 5.7 & 24.6 & 1.2 & 9.6 & 4.6 \\
\hline 59 & 0.5 & 0.0 & 96.5 & 28.1 & 98.6 & 2.4 & 1.0 & 74.0 & 1.4 & 21.8 & 0.9 & 0.7 & 1.2 \\
\hline 60 & 0.4 & 0.0 & 84.1 & 7.5 & 98.7 & 4.8 & 3.8 & 79.2 & 4.5 & 14.5 & 4.3 & 0.4 & 0.6 \\
\hline 61 & 0.4 & 0.1 & 125.6 & 68.5 & 98.8 & 3.6 & 3.6 & 83.3 & 11.4 & 11.9 & 6.6 & 0.4 & 0.8 \\
\hline 62 & 0.2 & 0.0 & 45.8 & 26.9 & 45.4 & 1.4 & 0.6 & 24.1 & 5.3 & 19.5 & 9.7 & 51.2 & 12.8 \\
\hline 63 & 0.8 & 0.2 & 124.8 & 18.5 & 91.1 & 1.4 & 0.2 & 71.1 & 4.3 & 17.7 & 7.8 & 8.2 & 4.6 \\
\hline 64 & 0.4 & 0.0 & 79.7 & 1.0 & 69.2 & 2.7 & 0.4 & 59.7 & 13.9 & 9.4 & 0.3 & 26.1 & 14.7 \\
\hline 65 & 0.5 & 0.1 & 66.1 & 50.6 & 40.3 & 1.2 & 0.5 & 25.5 & 32.9 & 13.1 & 10.3 & 43.8 & 40.1 \\
\hline 66 & 0.5 & 0.0 & 45.3 & 9.8 & 38.2 & 1.2 & 0.2 & 16.6 & 13.2 & 20.1 & 21.9 & 58.3 & 33.3 \\
\hline 67 & 0.5 & 0.2 & 117.2 & 7.8 & 90.0 & 0.6 & 0.3 & 55.7 & 14.4 & 33.4 & 6.5 & 3.0 & 3.1 \\
\hline 68 & 0.4 & 0.1 & 141.2 & 3.8 & 97.3 & 0.5 & 0.2 & & 3.0 & 58.7 & 3.0 & 0.3 & 0.4 \\
\hline 69 & 0.8 & 0.0 & 95.9 & 58.9 & 85.7 & 0.5 & 0.4 & 57.2 & 13.3 & 27.5 & 6.3 & 9.4 & 16.3 \\
\hline 70 & 0.9 & 0.0 & 37.7 & 20.8 & 65.0 & 1.6 & 0.9 & 46.8 & 21.3 & 16.0 & 7.6 & 18.9 & 21.6 \\
\hline 71 & 0.8 & 0.1 & 158.3 & 43.6 & 98.2 & 1.2 & 0.2 & 71.0 & 1.4 & 24.8 & 1.5 & 0.7 & 0.6 \\
\hline 72 & 0.9 & 0.1 & 24.7 & 14.8 & 14.6 & 2.0 & 0.8 & 9.2 & 1.4 & 2.9 & 0.9 & 69.3 & 10.1 \\
\hline 73 & 1.0 & 0.1 & 16.9 & 0.4 & 12.2 & 3.5 & 0.5 & 6.7 & 2.9 & 3.4 & 0.8 & 81.8 & 5.0 \\
\hline 74 & 0.2 & 0.0 & 22.1 & 4.0 & 6.1 & 10.8 & 9.3 & 3.8 & 2.2 & 1.9 & 1.5 & 81.2 & 13.3 \\
\hline & 0.5 & & 81.3 & & 76.2 & 2.5 & & 53.0 & & 20.3 & & 20.3 & \\
\hline
\end{tabular}


Table 21. Continued.

\begin{tabular}{|c|c|c|c|c|c|c|c|c|}
\hline \multirow[t]{2}{*}{ No. } & \multicolumn{2}{|c|}{$\mathrm{K} \mathrm{mg} \mathrm{g}^{-1}$} & \multicolumn{2}{|c|}{ Ca $\mathrm{mg} \mathrm{g}^{-1}$} & \multicolumn{2}{|c|}{$\mathrm{Mg} \mathrm{mg} \mathrm{g}^{-1}$} & \multicolumn{2}{|c|}{$\mathrm{Al} \mathrm{\textrm {mg } \mathrm { g } ^ { - 1 }}$} \\
\hline & mean & SD & mean & SD & mean & SD & mean & SD \\
\hline 1 & 5.7 & 1.8 & 1.5 & 1.0 & 6.1 & 3.5 & 60.3 & 18.8 \\
\hline 2 & 3.8 & 0.8 & 1.0 & 0.2 & 3.9 & 1.0 & 23.1 & 2.1 \\
\hline 3 & 0.8 & 0.1 & 0.3 & 0.1 & 0.8 & 0.2 & 16.1 & 1.4 \\
\hline 4 & 4.3 & 1.0 & 1.5 & 0.1 & 6.1 & 1.9 & 57.1 & 14.7 \\
\hline 5 & 7.2 & 0.1 & 6.5 & 0.3 & 9.4 & 0.3 & 43.2 & 1.5 \\
\hline 6 & 1.2 & 0.2 & 0.7 & 0.4 & 1.1 & 0.5 & 19.6 & 7.3 \\
\hline 7 & 2.3 & 0.3 & 1.3 & 0.1 & 2.1 & 0.2 & 35.8 & 4.0 \\
\hline 8 & 7.0 & 0.2 & 7.1 & 0.2 & 9.5 & 0.5 & 44.2 & 3.0 \\
\hline 9 & 6.2 & 0.7 & 5.6 & 0.8 & 7.8 & 1.5 & 33.1 & 8.2 \\
\hline 10 & 1.7 & 0.1 & 0.6 & 0.0 & 1.2 & 0.1 & 28.8 & 4.0 \\
\hline 11 & 7.9 & 0.5 & 7.1 & 0.1 & 11.7 & 0.2 & 63.8 & 1.9 \\
\hline 12 & 2.9 & 1.4 & 3.3 & 0.3 & 14.5 & 2.1 & 41.4 & 5.5 \\
\hline 13 & 7.9 & 2.6 & 1.4 & 0.4 & 10.5 & 0.7 & 37.5 & 4.2 \\
\hline 14 & 2.5 & 0.3 & 2.1 & 0.8 & 4.4 & 0.5 & 22.4 & 1.8 \\
\hline 15 & 3.1 & 0.1 & 2.6 & 0.0 & 6.5 & 0.3 & 27.2 & 0.5 \\
\hline 16 & 4.1 & 1.5 & 2.0 & 0.6 & 10.8 & 6.5 & 31.6 & 8.9 \\
\hline 17 & 4.2 & 0.3 & 2.3 & 0.7 & 7.8 & 0.9 & 29.3 & 1.1 \\
\hline 18 & 2.7 & 0.2 & 2.0 & 0.2 & 6.1 & 0.2 & 23.7 & 1.1 \\
\hline 19 & 3.5 & 0.6 & 3.2 & 1.6 & 7.1 & 2.6 & 26.2 & 5.7 \\
\hline 20 & 2.3 & 0.1 & 2.3 & 0.5 & 5.2 & 0.1 & 23.2 & 2.7 \\
\hline 21 & 6.0 & 0.5 & 4.4 & 1.2 & 9.9 & 1.4 & 36.2 & 2.9 \\
\hline 22 & 11.4 & 2.1 & 0.7 & 0.3 & 3.2 & 1.5 & 60.6 & 17.7 \\
\hline 23 & 9.6 & 3.5 & 0.4 & 0.3 & 3.9 & 0.9 & 77.2 & 5.0 \\
\hline 24 & 7.0 & 0.4 & 1.6 & 0.3 & 14.4 & 1.1 & 59.1 & 4.4 \\
\hline 25 & 5.0 & 0.3 & 1.9 & 0.8 & 7.5 & 0.9 & 24.3 & 1.6 \\
\hline 26 & 6.4 & 0.3 & 3.9 & 0.2 & 8.9 & 1.0 & 32.0 & 0.5 \\
\hline 27 & 4.6 & 0.2 & 0.4 & 0.0 & 2.9 & 0.2 & 29.8 & 1.3 \\
\hline 28 & 5.6 & 0.4 & 1.8 & 0.3 & 7.9 & 0.4 & 33.4 & 3.1 \\
\hline 29 & 13.0 & 1.2 & 1.7 & 0.9 & 2.4 & 0.6 & 46.2 & 6.2 \\
\hline 30 & 7.1 & 1.3 & 1.9 & 0.4 & 4.4 & 1.1 & 37.6 & 4.8 \\
\hline 31 & 4.9 & 0.7 & 0.8 & 0.2 & 4.9 & 1.1 & 25.7 & 3.1 \\
\hline 32 & 4.4 & 0.1 & 0.4 & 0.1 & 2.7 & 0.2 & 27.7 & 1.6 \\
\hline 33 & 6.1 & 0.2 & 1.5 & 0.1 & 2.2 & 0.1 & 35.6 & 2.5 \\
\hline 34 & 6.4 & 0.7 & 1.4 & 0.4 & 4.6 & 1.5 & 42.7 & 6.0 \\
\hline 35 & 3.9 & 0.9 & 0.2 & 0.0 & 2.6 & 0.2 & 30.1 & 0.9 \\
\hline 36 & 5.2 & 0.9 & 2.1 & 1.2 & 5.5 & 0.0 & 51.7 & 1.8 \\
\hline 37 & 4.8 & 0.3 & 1.8 & 0.3 & 4.3 & 0.2 & 20.3 & 3.7 \\
\hline 38 & 6.4 & 0.1 & 1.2 & 0.2 & 6.9 & 0.1 & 39.6 & 1.9 \\
\hline 39 & 8.5 & 0.7 & 1.4 & 0.2 & 5.5 & 0.5 & 45.8 & 8.3 \\
\hline 40 & 7.0 & 0.4 & 2.6 & 0.5 & 4.8 & 0.3 & 30.6 & 1.8 \\
\hline 41 & 10.1 & 0.1 & 2.2 & 0.2 & 7.8 & 0.2 & 52.4 & 1.6 \\
\hline 42 & 5.2 & 0.3 & 11.1 & 0.8 & 16.1 & 0.9 & 43.8 & 4.8 \\
\hline 43 & 3.5 & 0.2 & 3.9 & 0.2 & 5.3 & 0.2 & 21.5 & 1.7 \\
\hline 44 & 6.4 & 0.1 & 12.9 & 0.9 & 12.6 & 0.9 & 46.7 & 3.9 \\
\hline 45 & 9.2 & 0.2 & 1.5 & 0.1 & 5.5 & 0.4 & 51.3 & 3.1 \\
\hline 46 & 4.7 & 1.1 & 7.7 & 1.1 & 13.2 & 2.6 & 47.6 & 5.5 \\
\hline 47 & 0.7 & 0.1 & 32.4 & 11.3 & 20.5 & 3.3 & 78.1 & 14.3 \\
\hline 48 & 6.8 & 0.4 & 12.3 & 0.6 & 11.8 & 1.4 & 43.2 & 5.9 \\
\hline 49 & 4.6 & 0.5 & 15.4 & 2.6 & 17.9 & 2.9 & 49.3 & 7.0 \\
\hline 50 & 6.9 & 0.7 & 1.7 & 0.1 & 4.9 & 0.5 & 32.2 & 3.3 \\
\hline
\end{tabular}




\begin{tabular}{|c|c|c|c|c|c|c|c|c|}
\hline \multirow[t]{2}{*}{ No. } & \multicolumn{2}{|c|}{$\mathrm{K} \mathrm{mg} \mathrm{g}^{-1}$} & \multicolumn{2}{|c|}{ Ca mg g ${ }^{-1}$} & \multicolumn{2}{|c|}{$\mathrm{Mg} \mathrm{mg} \mathrm{g}^{-1}$} & \multicolumn{2}{|c|}{$\mathrm{Al} \mathrm{mg} \mathrm{g}^{-1}$} \\
\hline & mean & SD & mean & SD & mean & SD & mean & SD \\
\hline 51 & 7.0 & 0.3 & 14.0 & 0.7 & 14.3 & 0.2 & 53.6 & 1.7 \\
\hline 52 & 1.8 & 0.3 & 4.0 & 0.2 & 6.5 & 1.2 & 54.0 & 1.3 \\
\hline 53 & 4.3 & 0.9 & 7.9 & 2.1 & 14.1 & 2.0 & 43.2 & 4.1 \\
\hline 54 & 5.8 & 0.4 & 13.2 & 1.7 & 17.5 & 1.2 & 44.9 & 7.3 \\
\hline 55 & 8.3 & 0.4 & 1.4 & 0.1 & 6.7 & 0.5 & 42.9 & 3.6 \\
\hline 56 & 5.7 & 0.4 & 11.2 & 0.6 & 16.4 & 0.4 & 42.6 & 3.0 \\
\hline 57 & 7.6 & 0.8 & 1.5 & 0.1 & 6.0 & 0.6 & 32.0 & 3.5 \\
\hline 58 & 8.7 & 0.5 & 1.8 & 0.3 & 6.6 & 0.5 & 46.2 & 4.4 \\
\hline 59 & 7.0 & 0.1 & 15.1 & 0.8 & 13.8 & 1.6 & 49.9 & 6.0 \\
\hline 60 & 7.2 & 0.5 & 2.3 & 0.1 & 5.7 & 0.4 & 34.5 & 3.0 \\
\hline 61 & 7.8 & 0.4 & 2.6 & 1.5 & 4.9 & 0.4 & 41.5 & 5.8 \\
\hline 62 & 0.4 & 0.2 & 0.8 & 0.2 & 1.1 & 0.6 & 53.7 & 12.7 \\
\hline 63 & 5.4 & 1.3 & 10.0 & 1.9 & 14.4 & 2.8 & 40.4 & 11.0 \\
\hline 64 & 4.5 & 0.2 & 6.6 & 1.4 & 10.5 & 0.1 & 33.9 & 5.8 \\
\hline 65 & 0.1 & 0.1 & 2.0 & 3.0 & 1.7 & 1.9 & 145.7 & 9.6 \\
\hline 66 & 0.1 & 0.1 & 0.2 & 0.1 & 0.5 & 0.1 & 143.6 & 1.8 \\
\hline 67 & 0.1 & 0.2 & 7.6 & 7.4 & 5.3 & 3.8 & 90.0 & 14.3 \\
\hline 68 & 0.2 & 0.0 & 7.3 & 0.9 & 13.9 & 2.8 & 117.0 & 9.2 \\
\hline 69 & 0.2 & 0.0 & 5.8 & 4.5 & 3.3 & 2.2 & 114.6 & 12.5 \\
\hline 70 & 0.0 & 0.0 & 1.0 & 0.7 & 1.0 & 0.1 & 124.2 & 3.8 \\
\hline 71 & 4.8 & 0.3 & 16.0 & 2.6 & 18.8 & 2.8 & 52.9 & 15.2 \\
\hline 72 & 0.0 & 0.0 & 0.3 & 0.0 & 0.9 & 0.3 & 133.9 & 3.3 \\
\hline 73 & 0.1 & 0.1 & 0.3 & 0.1 & 0.4 & 0.0 & 111.0 & 3.9 \\
\hline 74 & 0.4 & 0.1 & 0.5 & 0.0 & 0.6 & 0.1 & 27.7 & 1.2 \\
\hline & 4.9 & & 4.3 & & 7.3 & & 48.8 & \\
\hline
\end{tabular}

Legend for Table 20 and 21:

$\begin{array}{llcl}\text { Village } & \text { LUS: } & \text { Soil type: } & \text { Abbreviations: } \\ & & & \\ 1=\text { Rompo } & 1 \text { = natural forest } & 1 \text { = Slopes, schist } & \text { LUS = land use system } \\ 2=\text { Nopu } & 2 \text { = forest fallow } & 2 \text { = Alluvial } & \text { n.m. }=\text { not measured } \\ 3=\text { Lempelero } & 3 \text { = agroforest } & \text { sediments } & \text { CEC = cation exchange } \\ 4=\text { Wuasa } & 4=\text { maize } & 3 \text { Slopes, weathered } & \text { capacity } \\ 5=\text { Wanga } & 5 \text { = grass fallow } & \text { phyllite } & \text { BD = bulk density } \\ & & & \text { BS = base saturation } \\ & & & \text { SE = standard error } \\ & & \text { y = years }\end{array}$


Table 22 Nutrient concentrations in soil water, location 1.

\begin{tabular}{|c|c|c|c|c|c|c|c|}
\hline Date & $\begin{array}{r}\text { N total } \\
\mathrm{mg} \mathrm{l}^{-1}\end{array}$ & pH & $\begin{array}{r}\mathrm{Ca} \\
\mathrm{mg} \mathrm{l^{-1 }}\end{array}$ & $\begin{array}{r}\mathrm{K} \\
\mathrm{mg} \mathrm{l^{-1 }}\end{array}$ & $\begin{array}{r}\mathrm{Mg} \\
\mathrm{mg} \mathrm{l}^{-1}\end{array}$ & $\begin{array}{r}\mathrm{Na} \\
\mathrm{mg} \mathrm{l}^{-1}\end{array}$ & \\
\hline 27. Feb 02 & 2.9 & 6.8 & 5.4 & 3.4 & 1.3 & 2.3 & Maize \\
\hline 08. Mar 02 & 3.1 & 7.2 & 6.1 & 3.7 & 1.5 & 2.6 & \\
\hline 16. Mar 02 & 3.2 & 6.6 & 7.2 & 3.9 & 1.7 & 2.7 & \\
\hline 22. Mar 02 & 4.6 & 7.0 & 7.4 & 3.3 & 1.7 & 2.3 & \\
\hline 31. Mar 02 & 4.1 & 7.3 & 7.2 & 3.7 & 2.0 & 2.3 & \\
\hline 06. Apr 02 & 3.4 & 7.2 & 7.2 & 2.6 & 1.6 & 2.2 & \\
\hline 13. Apr 02 & 2.8 & 6.8 & 6.8 & 2.4 & 1.6 & 2.0 & \\
\hline 21. Apr 02 & 2.6 & 7.2 & 7.3 & 2.2 & 1.6 & 1.7 & \\
\hline 05. May 02 & 2.1 & 6.1 & 7.0 & 2.3 & 1.7 & 1.9 & \\
\hline 11. May 02 & 2.0 & 6.7 & 6.1 & 2.2 & 1.5 & 1.5 & \\
\hline 19. May 02 & 1.9 & 6.2 & 6.3 & 2.3 & 1.6 & 2.0 & \\
\hline 26. May 02 & 2.1 & 6.4 & 6.0 & 2.3 & 1.4 & 2.1 & \\
\hline 01. Jun 02 & 2.2 & 7.4 & 7.3 & 2.4 & 1.8 & 2.3 & \\
\hline 10. Jun 02 & 1.0 & 6.8 & 5.6 & 2.2 & 1.4 & 2.0 & \\
\hline 16. Jun 02 & 1.5 & 5.9 & 5.5 & 2.3 & 1.4 & 2.1 & \\
\hline 22. Jun 02 & 1.6 & 6.4 & 5.7 & 2.1 & 1.3 & 1.9 & \\
\hline 29. Jun 02 & 1.6 & 6.5 & 5.0 & 1.9 & 1.2 & 2.0 & \\
\hline 08. Jul 02 & n.d. & 6.2 & 6.4 & 2.0 & 1.5 & 1.9 & \\
\hline 13. Jul 02 & 2.1 & 6.5 & 7.1 & 2.1 & 1.6 & 2.0 & \\
\hline 21. Jul 02 & 3.0 & 7.1 & 7.0 & 2.2 & 1.5 & 2.0 & \\
\hline 26. Jul 02 & 2.9 & 6.6 & 5.8 & 1.9 & 1.3 & 1.9 & \\
\hline 04. Aug 02 & 3.2 & 6.4 & 5.3 & 1.8 & 1.1 & 2.5 & \\
\hline 11. Aug 02 & 3.0 & 6.7 & 5.2 & 1.9 & 1.1 & 2.1 & \\
\hline 18. Aug 02 & 3.7 & 6.5 & 8.7 & 2.3 & 1.4 & 2.0 & \\
\hline 25. Aug 02 & 2.3 & 7.0 & 4.9 & 1.9 & 1.3 & 2.3 & \\
\hline 01. Sep 02 & 3.9 & 5.1 & 4.8 & 2.0 & 1.2 & 2.2 & \\
\hline Mean & 2.7 & 6.6 & 6.3 & 2.4 & 1.5 & $\overline{2.1}$ & \\
\hline SD & 0.9 & 0.5 & 1.0 & 0.6 & 0.2 & 0.3 & \\
\hline 22. Mar 02 & 2.3 & 6.5 & 13.6 & 4.4 & 3.0 & 4.16 & Natural forest \\
\hline 31. Mar 02 & 1.8 & 7.4 & 13.3 & 5.0 & 2.0 & 3.40 & \\
\hline 06. Apr 02 & 1.5 & 7.0 & 8.3 & 4.4 & 1.4 & 4.20 & \\
\hline 13. Apr 02 & 1.3 & 7.3 & 6.8 & 4.3 & 1.3 & 3.56 & \\
\hline 21. Apr 02 & 1.2 & 7.1 & 7.2 & 4.6 & 1.2 & 3.70 & \\
\hline 05. May 02 & 1.3 & 6.8 & 7.9 & 5.6 & 1.5 & 3.40 & \\
\hline 11. May 02 & 1.1 & 7.0 & 7.1 & 5.1 & 1.4 & 2.75 & \\
\hline 19. May 02 & 0.9 & 6.7 & 10.6 & 5.7 & 2.0 & 3.30 & \\
\hline 26. May 02 & 1.1 & 6.5 & 5.9 & 4.2 & 1.2 & 3.87 & \\
\hline 01. Jun 02 & 1.0 & 6.9 & 6.8 & 4.5 & 1.6 & 3.61 & \\
\hline 10. Jun 02 & 1.0 & 6.8 & 6.2 & 4.2 & 1.3 & 3.42 & \\
\hline 16. Jun 02 & 1.1 & 6.5 & 5.3 & 4.1 & 1.1 & 3.60 & \\
\hline 22. Jun 02 & 0.7 & 6.6 & 6.5 & 4.4 & 1.3 & 3.15 & \\
\hline 29. Jun 02 & 0.5 & 6.5 & 5.2 & 4.0 & 1.2 & 3.31 & \\
\hline 08. Jul 02 & 0.1 & 6.9 & 5.1 & 3.9 & 1.1 & 3.29 & \\
\hline 13. Jul 02 & 0.6 & 6.7 & 5.5 & 2.8 & 1.1 & 3.67 & \\
\hline 21. Jul 02 & 1.3 & 6.5 & 7.3 & 3.9 & 1.5 & 3.01 & \\
\hline 26. Jul 02 & 1.9 & 6.7 & 7.4 & 3.8 & 1.6 & 2.65 & \\
\hline 04. Aug 02 & 1.4 & 6.6 & 10.8 & 5.1 & 2.2 & 3.22 & \\
\hline Mean & 1.2 & 6.8 & 7.7 & 4.4 & 1.5 & 3.4 & \\
\hline SD & 0.5 & 0.3 & 2.6 & 0.7 & 0.5 & 0.41 & \\
\hline
\end{tabular}


Table 22. Continued.

\begin{tabular}{|c|c|c|c|c|c|c|}
\hline Date & $\begin{array}{r}\mathbf{N} \text { total } \\
\text { mg l }^{-1} \\
\end{array}$ & pH & $\begin{array}{r}\mathrm{Ca} \\
\mathrm{mg} \mathrm{l}^{-1}\end{array}$ & $\underset{\mathrm{mg} \mathrm{l}^{-1}}{\mathbf{K}}$ & $\begin{array}{r}\mathbf{M g} \\
\mathrm{mg} \mathrm{l}^{-1}\end{array}$ & $\begin{array}{r}\mathrm{Na} \\
\mathrm{mg} \mathrm{l}^{-1} \\
\end{array}$ \\
\hline 27. Feb 02 & 2.1 & 6.7 & 10.9 & 5.2 & 2.2 & 2.4 \\
\hline 08. Mar 02 & 1.6 & 7.1 & 8.6 & 4.9 & 1.9 & 1.8 \\
\hline 16. Mar 02 & 3.6 & 6.3 & 14.8 & 5.4 & 2.5 & 1.4 \\
\hline 22. Mar 02 & 3.9 & 7.1 & 13.4 & 4.8 & 2.3 & 1.5 \\
\hline 31. Mar 02 & 5.8 & 7.4 & 21.2 & 5.3 & 3.2 & 1.7 \\
\hline 06. Apr 02 & 6.4 & 7.2 & 25.1 & 6.8 & 4.0 & 1.6 \\
\hline 13. Apr 02 & 6.4 & 7.7 & 20.5 & 6.1 & 3.5 & 1.5 \\
\hline 21. Apr 02 & 6.0 & 7.2 & 23.2 & 6.2 & 3.8 & 1.4 \\
\hline 05. May 02 & 4.5 & 6.6 & 18.8 & 5.7 & 3.4 & 1.6 \\
\hline 11. May 02 & 3.0 & 6.9 & 14.1 & 4.8 & 2.6 & 1.3 \\
\hline 19. May 02 & 1.9 & 6.7 & 18.8 & 4.8 & 3.3 & 1.6 \\
\hline 26. May 02 & 1.9 & 6.6 & 16.2 & 4.2 & 2.7 & 1.6 \\
\hline 01. Jun 02 & 2.6 & 7.2 & 24.7 & 4.4 & 3.9 & 1.7 \\
\hline 10. Jun 02 & 0.3 & 6.7 & 28.6 & 3.6 & 4.3 & 1.5 \\
\hline 16. Jun 02 & 2.5 & 6.4 & 18.0 & 4.0 & 2.9 & 1.5 \\
\hline 22. Jun 02 & 0.8 & 6.2 & 12.1 & 3.8 & 2.1 & 1.4 \\
\hline 29. Jun 02 & 0.4 & 6.6 & 13.1 & 3.6 & 2.2 & 1.4 \\
\hline 08. Jul 02 & 1.2 & 7.1 & 12.1 & 3.5 & 2.1 & 1.5 \\
\hline 13. Jul 02 & 0.0 & 6.5 & 15.9 & 3.9 & 2.5 & 1.6 \\
\hline 21. Jul 02 & 2.3 & 6.5 & 14.5 & 3.9 & 1.9 & 1.5 \\
\hline 26. Jul 02 & 3.0 & 6.4 & 13.3 & 3.9 & 2.0 & 1.4 \\
\hline 04. Aug 02 & 4.4 & 6.3 & 16.5 & 4.7 & 2.4 & 1.7 \\
\hline 11. Aug 02 & 5.3 & 6.6 & 19.1 & 4.0 & 2.5 & 1.5 \\
\hline 18. Aug 02 & 2.7 & 6.9 & 10.0 & 2.9 & 1.3 & 1.5 \\
\hline 25. Aug 02 & 4.9 & 6.5 & 11.8 & 3.4 & 1.8 & 1.6 \\
\hline 01. Sep 02 & 4.7 & 5.9 & 16.8 & 3.7 & 2.5 & 1.7 \\
\hline Mean & 2.7 & 6.6 & 6.3 & 2.4 & 1.5 & 2.1 \\
\hline SD & 1.9 & 0.4 & 5.0 & 1.0 & 0.8 & 0.2 \\
\hline
\end{tabular}

\section{Agroforest}


Table 23. Nutrient concentrations in soil water, location 2.

\begin{tabular}{|c|c|c|c|c|c|c|}
\hline \multicolumn{2}{|c|}{$\begin{array}{r}\text { Date } \mathrm{N} \text { total } \\
\mathrm{mg} \mathrm{l}^{-1}\end{array}$} & pH & $\begin{array}{r}\text { Ca } \\
\mathrm{mg} \mathrm{l}^{-1}\end{array}$ & $\begin{array}{r}\mathrm{K} \\
\mathrm{mg} \mathrm{l}^{-1}\end{array}$ & $\begin{array}{r}\text { Mg } \\
\mathrm{mg} \mathrm{l}^{-1}\end{array}$ & $\begin{array}{r}\mathrm{Na} \\
\mathrm{mg} \mathrm{l}^{-1}\end{array}$ \\
\hline 31. Mar 02 & 0.2 & 7.7 & 1.3 & 2.4 & 1.0 & 1.6 \\
\hline 06. Apr 02 & 0.1 & 7.1 & 1.8 & 0.4 & 1.8 & 1.3 \\
\hline 13. Apr 02 & 0.2 & 6.4 & 6.5 & 0.6 & 1.2 & 1.7 \\
\hline 21. Apr 02 & 0.1 & 7.1 & 1.0 & 0.4 & 1.1 & 0.9 \\
\hline 05. May 02 & 0.3 & 5.7 & 0.9 & 0.4 & 1.0 & 1.1 \\
\hline 11. May 02 & 0.3 & 6.7 & 1.2 & 0.4 & 1.2 & 1.7 \\
\hline 19. May 02 & 0.4 & 5.8 & 0.6 & 0.7 & 0.5 & 2.1 \\
\hline 26. May 02 & 1.1 & 6.5 & 4.6 & 4.0 & 1.0 & 4.0 \\
\hline 01. Jun 02 & 0.3 & 6.7 & 2.8 & 0.9 & 2.8 & 1.9 \\
\hline 16. Jun 02 & 0.1 & 5.4 & 0.3 & 0.5 & 0.3 & 1.1 \\
\hline 22. Jun 02 & 0.1 & 6.3 & 0.8 & 0.5 & 0.8 & 1.0 \\
\hline 29. Jun 02 & 0.1 & 5.8 & 0.3 & 0.5 & 0.4 & 0.9 \\
\hline 21. Jul 02 & 0.1 & 7.3 & 0.4 & 0.5 & 0.3 & 1.2 \\
\hline 04. Aug 02 & 1.8 & 6.1 & 6.7 & 1.8 & 1.4 & 1.4 \\
\hline Mean & 0.4 & 6.5 & 2.1 & 1.0 & 1.1 & 1.6 \\
\hline SD & 0.5 & 0.7 & 2.2 & 1.0 & 0.7 & 0.8 \\
\hline 31. Mar 02 & 3.00 & 6.84 & 4.34 & 2.42 & 1.31 & 1.35 \\
\hline 06. Apr 02 & 1.92 & 7.06 & 2.90 & 0.45 & 0.88 & 1.21 \\
\hline 13. Apr 02 & 1.19 & 6.28 & 1.98 & 0.48 & 0.72 & 1.05 \\
\hline 21. Apr 02 & 1.09 & 6.38 & 1.22 & 0.24 & 0.49 & 0.71 \\
\hline 05. May 02 & 0.81 & 4.73 & 1.17 & 0.38 & 0.53 & 1.26 \\
\hline 11. May 02 & 0.56 & 6.94 & 0.80 & 0.35 & 0.37 & 0.85 \\
\hline 19. May 02 & 0.53 & 5.47 & 0.90 & 0.85 & 0.35 & 1.38 \\
\hline 26. May 02 & 0.68 & 6.71 & 0.73 & 0.64 & 0.21 & 1.26 \\
\hline 01. Jun 02 & 0.39 & 7.26 & 0.94 & 0.72 & 0.40 & 1.23 \\
\hline 10.Jun 02 & 0.17 & 6.91 & 0.79 & 0.60 & 0.14 & 1.13 \\
\hline 16. Jun 02 & 0.16 & 5.22 & 0.93 & 0.52 & 0.33 & 1.08 \\
\hline 22. Jun 02 & 0.55 & 5.45 & 0.97 & 0.51 & 0.30 & 1.03 \\
\hline 29. Jun 02 & 0.63 & 5.22 & 0.90 & 0.54 & 0.32 & 1.10 \\
\hline 08. Jun 02 & 0.28 & 5.02 & 0.79 & 0.64 & 0.26 & 1.07 \\
\hline 13. Jun 02 & 0.34 & 6.13 & 1.28 & 0.79 & 0.31 & 1.61 \\
\hline 21. Jul 02 & 0.90 & 4.73 & 0.96 & 0.77 & 0.27 & 1.64 \\
\hline 26. Jun 02 & 0.95 & 5.30 & 1.06 & 0.66 & 0.30 & 1.73 \\
\hline 04. Aug 02 & 0.53 & 5.57 & 0.83 & 0.63 & 0.19 & 1.83 \\
\hline 25. Aug 02 & 0.58 & 5.95 & 0.69 & 0.52 & 0.13 & 1.44 \\
\hline 01. Sep 02 & 0.64 & 3.82 & 0.83 & 0.50 & 0.22 & 1.91 \\
\hline Mean & 0.8 & 5.8 & 1.2 & 0.7 & 0.4 & 1.3 \\
\hline SD & 0.7 & 0.9 & 0.9 & 0.4 & 0.3 & 0.3 \\
\hline
\end{tabular}

\section{Natural Forest}

Maize 
Table 24. Nutrient concentrations in rain water.

\begin{tabular}{|c|c|c|c|c|c|c|c|}
\hline Date & $\begin{array}{r}\mathrm{N} \text { total } \\
\mathrm{mg} \mathrm{l}^{-1}\end{array}$ & pH & $\begin{array}{r}\text { Ca } \\
\mathbf{m g ~ l}^{-1}\end{array}$ & $\begin{array}{r}\mathbf{K} \\
\mathrm{mg} \mathrm{l}^{-1} \\
\end{array}$ & $\begin{array}{r}\text { Mg } \\
\mathrm{mg} \mathrm{l}^{-1}\end{array}$ & $\begin{array}{r}\mathrm{Na} \\
\mathrm{mg} \mathrm{l}^{-1} \\
\end{array}$ & \\
\hline 21. Apr 02 & 0.1 & 7.6 & 0.2 & 0.4 & 0.0 & 0.4 & Location 1 \\
\hline 05. May 02 & 0.1 & 7.5 & 0.2 & 0.4 & 0.1 & 0.2 & \\
\hline 11. May 02 & 0.3 & 7.4 & 0.1 & 1.1 & 0.1 & 0.2 & \\
\hline 26. May 02 & 0.2 & 7.1 & 0.3 & 0.7 & 0.0 & 0.9 & \\
\hline 01. Jun 02 & 0.3 & 7.6 & 0.6 & 0.8 & 0.2 & 0.9 & \\
\hline 10. Jun 02 & 0.0 & 7.1 & 0.3 & 1.1 & 0.0 & 0.6 & \\
\hline 16. Jun 02 & 0.0 & 7.1 & 0.2 & 0.5 & -0.1 & 0.4 & \\
\hline 22. Jun 02 & 0.0 & 6.5 & 0.3 & 0.5 & 0.0 & 0.5 & \\
\hline 26. Jul 02 & 0.1 & 7.1 & 0.3 & 0.6 & 0.0 & 0.6 & \\
\hline 25. Aug 02 & 0.4 & 5.2 & 1.1 & 0.7 & 0.1 & 0.8 & \\
\hline 01. Sep 02 & 0.6 & 7.0 & 0.7 & 0.6 & 0.0 & 0.8 & \\
\hline Mean & 0.2 & 7.0 & 0.4 & 0.7 & 0.0 & $\overline{0.6}$ & \\
\hline SD & 0.2 & 0.7 & 0.3 & 0.3 & 0.1 & 0.3 & \\
\hline 31. Mar 02 & 0.0 & 7.6 & 0.3 & 2.1 & -0.1 & 0.2 & Location 2 \\
\hline 6. Apr 02 & 0.1 & 7.2 & 0.2 & 0.3 & 0.0 & 0.3 & \\
\hline 13. Apr 02 & 0.0 & 5.5 & 0.3 & 0.4 & 0.1 & 0.2 & \\
\hline 21. Apr 02 & 0.0 & 6.9 & 0.1 & 0.9 & 0.0 & 0.2 & \\
\hline 5. May 02 & n.d. & 5.8 & 0.1 & 0.6 & 0.1 & 0.3 & \\
\hline 11. May 02 & 0.0 & 7.1 & 0.1 & 0.3 & 0.1 & 0.2 & \\
\hline 26. May 02 & 0.1 & 6.7 & 0.3 & 0.7 & 0.0 & 0.7 & \\
\hline 1. Jun 02 & 0.1 & 7.0 & 0.9 & 0.8 & 0.4 & 1.0 & \\
\hline 10. Jun 02 & 0.0 & 7.1 & 0.3 & 1.0 & 0.0 & 0.6 & \\
\hline 16. Jun 02 & 0.0 & 5.7 & 0.3 & 0.5 & 0.1 & 0.4 & \\
\hline 22. Jun 02 & 0.0 & 5.8 & 0.3 & 0.5 & 0.0 & 0.5 & \\
\hline 21. Jul 02 & 0.5 & 7.4 & 0.5 & 0.7 & 0.0 & 1.0 & \\
\hline 25. Aug 02 & 0.5 & 7.2 & 0.6 & 0.6 & 0.2 & 0.8 & \\
\hline 1. Sep 02 & 0.3 & 6.9 & 0.5 & 0.6 & 0.1 & 0.7 & \\
\hline 22. Sep 02 & 0.1 & 6.6 & 0.3 & 0.7 & 0.1 & 0.5 & \\
\hline 29. Sep 02 & 0.2 & 0.8 & 0.2 & 0.4 & 0.1 & 0.3 & \\
\hline Mean & 0.1 & 6.3 & 0.3 & 0.7 & 0.1 & 0.5 & \\
\hline SD & 0.2 & 1.6 & 0.2 & 0.4 & 0.1 & 0.3 & \\
\hline
\end{tabular}


Table 25. Mean soil texture in different village areas and the soil type classification

\begin{tabular}{lcccc}
\hline Village & Clay \% & Sand \% & Silt \% & Soiltype \\
\hline 1. Rompo & $13.4(2.2)$ & $50.1(6.3)$ & $36.5(5.1)$ & A \\
2. Nopu & $13.2(1.4)$ & $48.9(1.8)$ & $38.0(2.8)$ & A \\
3. Lempelero & $15.0(1.5)$ & $51.4(2.7)$ & $33.6(1.6)$ & A \\
4. Wuasa & $20.5(1.5)$ & $41.5(3.6)$ & $38.0(2.6)$ & B \\
5. Wanga & $49.9(5.8)$ & $17.0(3.9)$ & $33.1(2.3)$ & C \\
\hline
\end{tabular}

Table 26. Nutrients removed by harvest compartments, $\mathrm{kg} \mathrm{ha}^{-1} \mathrm{a}^{-1}$

\begin{tabular}{lrrrrrr}
\hline \multicolumn{2}{l}{ Location } & $\mathrm{N}$ & $\mathrm{P}$ & $\mathrm{Ca}$ & $\mathrm{K}$ & $\mathrm{Mg}$ \\
\hline 1 & Maize, total & $\mathbf{3 8}$ & $\mathbf{5 . 9}$ & $\mathbf{0 . 4}$ & $\mathbf{1 3 . 8}$ & $\mathbf{2 . 2}$ \\
1 & Maize seeds & 38 & 5.6 & 0.3 & 10.0 & 2.1 \\
1 & Cob stalks & 0 & 0.3 & 0.1 & 3.8 & 0.1 \\
1 & Agroforestry total & $\mathbf{5 7}$ & $\mathbf{9 . 1}$ & $\mathbf{1 2 . 2}$ & $\mathbf{4 1 . 8}$ & $\mathbf{6 . 4}$ \\
1 & Coffee & 29 & 2 & 3.5 & 31 & 2 \\
1 & Cocoa & 11 & 3 & 0 & 6 & 2 \\
1 & Candle Nut & 17 & 4.1 & 8.7 & 4.8 & 2.4 \\
1 & Shells & 1 & 0.1 & 8.0 & 1.5 & 0.8 \\
1 & Kernel & 16 & 4.0 & 0.7 & 3.3 & 1.6 \\
2 & Maize. total & $\mathbf{4 4}$ & $\mathbf{1 2 . 7}$ & $\mathbf{0 . 5}$ & $\mathbf{1 9 . 7}$ & $\mathbf{4 . 1}$ \\
2 & Maize seeds & 44 & 12.4 & 0.4 & 15.3 & 3.9 \\
2 & Cob stalks & 0 & 0.3 & 0.1 & 4.4 & 0.2 \\
\hline
\end{tabular}




\section{Acknowledgements}

I would like to thank all colleges and friends who helped me with this thesis. I am especially grateful to Prof. Dr. E. Veldkamp, Dr. R. Brumme, and Dr. M. Corre for supervising the thesis and giving advice and help continuously during preparation, fieldwork, data evaluation and interpretation.

Special thanks to Prof. Dr. M. Schaefer for giving me the opportunity to defend this thesis at the faculty of biology and for taking over the reference. I also thank Prof. Dr. Ehlers for taking over the second reference at the faculty of biology.

I am also very grateful to Prof. Iswandi Anas, our counterpart in Bogor, for his help, support and hospitality in Bogor and Palu.

I would like to thank Subproject Z2 and the Institute for Bioclimatology, especially $\mathrm{Mr}$. Kreilein and Dr. Oltchev, for contributing climatic data.

I am especially grateful to all farmers and village heads in the research area in Sulawesi for their hospitality and openness, which allowed me to conduct my research there, and made my stay in Sulawesi unforgettable.

Many thanks to the laboratory staff in Göttingen at the IBW for their invaluable technical support in analysing many soil samples, and for Robert Karsten and the laboratory staff in Palu for analysing soilwater, rainwater and litter samples.

I thank all STORMA collegues for their helpfulness in many ways during my stay in Indonesia. I would like to mention especially Alex Kleinhans, Frank Brodbeck, Stefan Schwarze, Günther Burckhard, Christian Schulze, Gary Schlosser, Alex zu Dreele, and the supervisors of subproject D2, Prof. Dr. Kroschel and Prof. Dr. Claassen.

Special thanks to the STORMA coordination team in Palu and Göttingen, and especially to all drivers of the project in Palu for their support.

This study was done in subproject D4 of the SFB 552 STORMA, and was funded by DFG (Deutsche Forschungsgemeinschaft). 


\section{Curriculum vitae}

Georg Sebastian Dechert

Diplombiologe

geboren am 21. 10. 1972 in Frankfurt am Main

06/79 - 07/92 Waldorfschule Frankfurt/Main

Abschluß: Abitur

08/92 - 10/93 Zivildienst bei der Naturschutzorganisation ”Schutzstation Wattenmeer e.V.” in St.-Peter-Ording

10/93 - 07/95 Grundstudium Biologie an der Georg-August-Universität Göttingen Abschluß: Vordiplom

09/95 - 06/96 Studium der Biologie am King’s College London (University of London)

10/96 - 04/99 Hauptstudium Biologie an der Georg-August-Universität Göttingen Hauptfach Zoologie, Nebenfächer Phytomedizin und Bodenkunde Abschluß: Hauptdiplom

07/98 - 04/99 Diplomarbeit am Institut für Phytopathologie und Pflanzenschutz der Universität Göttingen. Thema: Interaktionen zwischen Schadinsekten auf der Kulturpflanze Raps

01/00 - 11/00 Anstellung als wissenschaftlicher Mitarbeiter an der Firma Dr. U. Noack-Laboratorium für angewandte Biologie, Sarstedt

11/00 - 09/03 Wissenschaftlicher Angestellter am Institut für Bodenkunde und Waldernährung der Universität Göttingen, Mitarbeit am DFG Sonderforschungsbereich „STORMA“ in Indonesien 